\title{
AFTER PROMETHEUS, ARE HUMAN GENES PATENTABLE SUBJECT MATTER?
}

\author{
DOUGLAS L. ROGERS ${ }^{\dagger}$
}

\begin{abstract}
On April 15, 2013, the U.S. Supreme Court heard oral arguments in Association for Molecular Pathology v. Myriad Genetics, Inc. on the question, "Are human genes patentable?" This article argues that human genes are not patentable and that isolating a gene from its surroundings in a human body-or creating synthetically what exists in nature as DNA-does not cause the DNA to become patentable subject matter. The isolated DNA segments of claim 1 have the identical nucleotide sequence and the same function as native DNA, and the isolated DNA of claim 1 do not reflect the marked changes required under Chakrabarty, or the inventive step required under Prometheus, to change an unpatentable product of nature into patentable subject matter. Claim 2 describes those nucleotides in the DNA sequence that code for the polypeptide identified in the Myriad Genetics patent specification and simply reflects the genetic code, an unpatentable law of nature. Since no inventive step has been added to the law of nature, claim 2 constitutes unpatentable subject matter under Prometheus. The Federal Circuit's contrary decision in Myriad Genetics disregards 150 years of Supreme Court cases that physical phenomena found in nature and laws of nature are not patentable subject matter and threatens to enclose building blocks of nature under federal patent law. The Supreme Court should reverse the Federal Circuit's decision in Myriad Genetics on claims 1 and 2.
\end{abstract}

\footnotetext{
${ }^{\dagger}$ Adjunct professor of law at The Ohio State University Moritz College of Law and a 1971 graduate of Yale Law School. In 2008, Professor Rogers retired as a partner in the Intellectual Property Group of Vorys, Sater, Seymour and Pease LLP. He gratefully acknowledges the comments of Professor Joshua Sarnoff to an earlier draft of this article without suggesting that Professor Sarnoff agrees with the statements made in this article.
} 


\section{INTRODUCTION}

"The grant of an exclusive right to an invention was the creation of societyat odds with the inherent free nature of disclosed ideas-and was not to be freely given."

$$
\text { - Justice Clark for a unanimous Supreme Court }{ }^{1}
$$

"Most industries could get along fine without patent protection."

$$
\text { - Judge Richard A. Posner }{ }^{2}
$$

"Life's instructions ought not be controlled by legal monopolies at the whim of Congress or the courts."

$$
\text { - James D. Watson }{ }^{3}
$$

"Diagnostic genetic testing for the existence of BRCA mutations is ... an important consideration in the provision of clinical care for breast or ovarian cancer." Myriad Genetics uses its patents in cancer-screening genetic tests and has sued companies using competing genetic tests for patent infringement. ${ }^{5}$ Meanwhile, patients claim that they have been unable to obtain needed genetic testing as the result of Myriad Genetics' patent enforcement. ${ }^{6}$ The Association for Molecular Pathology filed suit and obtained a U.S. District Court declaration that Myriad Genetics' patents on isolated DNA segment were invalid. When the Federal Circuit reversed the District Court decision, the Association petitioned the U.S. Supreme Court to hear the case. ${ }^{7}$

On November 30, 2012, the Supreme Court granted certiorari in Association for Molecular Pathology v. Myriad Genetics, Inc. on the

\footnotetext{
${ }^{1}$ Graham v. John Deere Co., 383 U.S.1, 9 (1966).

${ }^{2}$ Richard A. Posner, Why There Are Too Many Patents in America, THE ATLANTIC, July 12, 2012, http://www.theatlantic.com/business/archive/2012/07/why-there-aretoo-many-patents-in-america/259725.

${ }^{3}$ Brief of James D. Watson, Ph.D. as Amicus Curiae in Support of Neither Party at 1, Assoc. for Molecular Pathology v. Myriad Genetics, Inc., No. 12-398 (U.S. Jan. 31, 2013), 2013 WL 432951, at*1. James Watson is, of course, the co-discoverer of the double helix structure of deoxyribonucleic acid (and winner of the Nobel Prize in Physiology or Medicine in 1962).

${ }^{4}$ Assoc. for Molecular Pathology v. Myriad Genetics, Inc., 689 F.3d 1303, 1314

(Fed. Cir. 2012).

${ }^{5}$ Id. at $1314-16$.

${ }^{6} \mathrm{Id}$. at 1315.

${ }^{7}$ Petition for a Writ of Certiorari, Assoc. for Molecular Pathology v. Myriad Genetics, Inc., No. 12-398 (U.S. Sept. 25, 2012), 2012 WL 4502947.
} 
question, "Are human genes patentable?" 8 The composition claims of the patents at issue "cover two 'isolated' human genes, BRCA1 and BRCA2 $\ldots$ and certain alterations, or mutations, in these genes associated with a predisposition to breast and ovarian cancers." In spite of an earlier remand from the Supreme Court for the Federal Circuit to reconsider its 2011 decision in Myriad Genetics in light of the Supreme Court's 2012 decision in Mayo Collaborative Services v. Prometheus Laboratories, Inc., ${ }^{10}$ the Federal Circuit held-in a conflicted opinion with two separate concurrences - that the BRCA gene claims constituted patentable subject matter. $^{11}$

Each of the Federal Circuit's Myriad Genetics opinions either disregarded or misapplied the Supreme Court's unanimous decision in Mayo Collaborative Services v. Prometheus Laboratories, Inc. that certain medical diagnostic claims constituted unpatentable laws of nature. ${ }^{12}$ The Prometheus Court declared that over 150 years of Supreme Court

${ }^{8}$ Assoc. for Molecular Pathology v. Myriad Genetics, Inc., 689 F.3d 1303 (Fed. Cir. 2012), cert. granted, 133 S. Ct. 694 (Nov. 30, 2012), 2012 WL 4508118. The Federal Circuit decided the case for the second time on August 16, 2012, with three separate opinions, including one in dissent, reported as Myriad Genetics, 689 F.3d 1303. The US Patent and Trademark Office was dismissed from the suit earlier, and that dismissal was not appealed. See Petition for a Writ of Certiorari, Myriad Genetics, No. 12-398, 2012 WL 4502947, at *ii.

${ }^{9}$ Myriad Genetics, 689 F.3d at 1304.

${ }^{10}$ Mayo Collaborative Servs. v. Prometheus Labs., Inc., 132 S. Ct. 1289 (2011).

${ }^{11} 689$ F.3d at 1333. The District Court's decision finding the product claims to constitute unpatentable subject matter is Assoc. for Molecular Pathology v. U.S. Patent and Trademark Office, 702 F.Supp.2d 181 (S.D.N.Y. 2010). The Federal Circuit's initial decision reversing the District Court's decision is reported at 653 F.3d 1329 (Fed. Cir. 2011). There were both process and product claims at issue, and for a detailed discussion of the 2011 Federal Circuit decision in Myriad Genetics on claim 1 of the product patents, see Douglas L. Rogers, Coding For Life-Should Any Entity Have The Exclusive Right To Use And Sell Isolated DNA?, 12 U. PitT. J. TeCh. L. \& POL'Y 1 (Fall 2011). At 132 S. Ct. 1794 (2012), the Supreme Court granted certiorari, vacated, and remanded the 2011 decision in Myriad Genetics for reconsideration in light of the Supreme Court's intervening decision in Prometheus.

${ }^{12}$ Prometheus, 132 S. Ct. at 1294. In Prometheus, the District Court for the Southern District of California had granted summary judgment invalidating the patents. 2008 WL 878910, *14 (S.D. Cal. 2008). The Federal Circuit reversed. 581 F.3d 1336, 1339 (Fed. Cir. 2009). The Supreme Court granted certiorari and vacated-at 130 S. Ct. 3543 (2010) - the Federal Circuit's decision for reconsideration in light of its earlier decision in Bilski v. Kappos, 130 S. Ct. 3218 (2010). On reconsideration the Federal Circuit again reversed the decision of the District Court. 628 F.3d 1347, 1349 (Fed. Cir. 2010). Then the Supreme Court unanimously reversed the Federal Circuit on the merits. 132 S. Ct. 1289, 1305 (2012). 
precedents "insist that a process that focuses upon the use of a natural law also contain other elements or a combination of elements, sometimes referred to as an 'inventive concept,' sufficient to ensure that the patent in practice amounts to significantly more than a patent upon the natural law itself." 13 The Supreme Court further cautioned that patents tying up uses of the laws of nature could inhibit future innovation. ${ }^{14}$

This article argues that the Supreme Court should reverse the Federal Circuit's decision in Myriad Genetics and continue to protect what has existed as part of the public domain throughout our history-physical phenomena and laws of nature. Under Prometheus and other Supreme Court precedents, patent claims that focus on a natural law must contain an inventive concept and must not merely apply known practices or limitations. Myriad Genetics' Claim 1 simply describes a physical phenomenon and a law of nature - specified sequences of DNA that result in the creation of specific amino acids-without any inventive concept. Myriad Genetics' Claim 2 is a subset of Claim 1 and simply describes the DNA nucleotides that create the amino acids pursuant to a law of natureagain without any inventive concept.

Part I of this article analyzes the Supreme Court precedents that limit exclusive patent rights preventing other market participants from freely using laws of nature and physical phenomena to compete. Specifically, part I argues that Prometheus clarifies the boundaries for patent eligible subject matter in the genetic age so building blocks of nature remain free for all to use. ${ }^{15}$

${ }^{13}$ Prometheus, 132 S. Ct. at 1294 (emphasis added).

${ }^{14} I d$. at 1301 (citing Mark A. Lemley, Michael Risch, Ted Sichelman, \& R. Wolk Wagner, Life After Bilski, 63 STAN. L.REV. 1315 (2011); CHRISTINA BOHANNAN \& Herbert HovenKamp, Creation Without Restraint: Promoting Liberty AND RIVALRY IN INNOVATION 112 (Oxford University Press 2011) [hereinafter Creation]; William M. Landes \& Richard A. Posner, The Economic Structure of Intellectual Property LaW (Harvard University Press 2003) [hereinafter ECONOMIC STRUCTURE]).

${ }^{15}$ See Funk Bros. Seed Co. v. Kalo Inoculant Co., 333 U.S. 127, 130 (1948) ("The qualities of those bacteria, like the heat of the sun, electricity, or the qualities of metals, are part of the storehouse of knowledge of all men ... manifestations of laws of nature, free to all men and reserved exclusively to none."); Joshua D. Sarnoff, Patent-Eligible Inventions After Bilski: History And Theory, 63 HASTINGS L.J. 53, 57-58 (2011) ("The patent system is not supposed to reward discoveries of basic science and at least some other kinds of human discoveries, no matter how much money, effort, creativity and disclosure went into developing and disseminating that highly useful knowledge."); Allen K. Yu, Within Subject Matter Eligibility—A Disease And A Cure, 84 S. CAL. L. REv. 387, 428 (2011) ("The Court should redefine its vague and relatively weak judicial prohibition against the patenting of nature and abstract ideas in terms of a stronger, more explicit 
Part II of this article shows that the words "invention," "new," and "useful" in 35 U.S.C. $\S 101$ are consistent with the Supreme Court's exclusion of physical phenomena and laws of nature from patent enclosure. ${ }^{16}$ Part II also shows that the term "new" in $\S 101$ and in earlier statutes has retained for over 200 years a different meaning than "novelty" and "prior art" in $\S \S 102$ and 103 . The exclusions of physical phenomena and laws of nature are therefore not the results of a judicially active court limiting the will of Congress.

Part III.A of this article analyzes the three conflicting opinions in the Federal Circuit's 2012 Myriad Genetics decision. Part III.B argues that the conclusion of Judges Lourie and Moore-that the isolated DNA segments of Claim 1 constitute patentable subject matter-disregards the Supreme Court's decisions in Prometheus, Diamond v. Chakrabarty, ${ }^{17}$ and Funk Brothers Seed Co. v. Kalo Inoculant Co ${ }^{18}$ Part III.C argues that even if the isolated cDNA segments of Claim 2 do not fit within the guidance of Chakrabarty and Funk Brothers, the isolated cDNA segments under Prometheus cover an unpatentable law of nature - the genetic code.

This article concludes that the Federal Circuit's disregard in Myriad Genetics of the laws of nature and the requirement of an inventive concept where the patent claims focus on laws of nature allows enclosure of the building blocks of nature that should instead remain part of the public domain.

\section{PATENT LAW AND EXClusions From Patentable SubJect MATTER}

\section{A. Foundations of Patent Law}

Patents are restrictions on competition imposed by the federal government. ${ }^{19}$ The constitutional basis for patents is Article I, $\S 8$, clause 8

prohibition against the patenting of "basic tools of scientific and technological work." (quoting Gottschalk v. Benson, 409 U.S. 63, 67 (1972)).

${ }^{16}$ See, e.g., Efthimios Parasidis, A Uniform Framework For Patent Eligibility, 85 TUL. L. REV. 323, 339 (2010) ("[N]atural principles may not receive patent protection because, under the terms of the patent statute, they can never be deemed new."). For a discussion of the enclosure of what had been held in common in England, see James Boyle, The Public Domain: Enclosing the Commons of THE MIND 43-53 (Yale University Press 2008) ("Enclosure did not necessarily mean physical fencing, though that could happen. More likely, the previously common land was converted into private property, generally controlled by a single landholder.").

${ }^{17}$ Diamond v. Chakrabarty, 100 S. Ct. 2204, 2207-12 (1980).

${ }_{18}^{18} 333$ U.S. at 130.

1935 U.S.C. § 154(a)(1) provides, "Every patent shall contain ... a grant to the 
of the U.S. Constitution (the "Patent Clause"). It grants Congress the power " $[\mathrm{t}$ ] p promote the Progress of . . . useful Arts, by securing for limited Times to . . . Inventors the exclusive Right to their respective . . . Discoveries ...."20 The statutory basis for patents is 35 U.S.C. $\S 101$, which provides, "[w]hoever invents or discovers any new and useful process, machine, manufacture, or composition of matter, or any new and useful improvement thereof, may obtain a patent therefor, subject to the conditions and requirements of this title. ${ }^{, 21}$ The Supreme Court refers to these categories (process, machine, manufacture, composition of matter, and improvement thereof) as patentable subject matter. ${ }^{22}$

Even though the Supreme Court has said Congress intended courts to give patent statutes "wide scope," 23 for over 150 years the Court has

patentee ... of the right to exclude others from making, using, offering for sale, or selling the invention throughout the United States ...." Professor Lessig observed, "A patent is a form of governmental regulation. It is a state-backed monopoly granting exclusive rights to an 'inventor' for an invention deemed useful, novel, and nonobvious." LAWRENCE LESSIG, ThE Future OF IDEAS: THE FATE OF THE COMMONS IN A CONNECTED WORLD 205 (Random House 2001). In Precision Instrument Mfg. Co. v. Automotive Maintenance Machinery Co., 324 U.S. 806, 816 (1945), the Supreme Court said that "a patent is an exception to the general rule against monopolies and to the right to access to a free and open market."

${ }^{20}$ The complete text of clause 8 is, "To promote the Progress of Science and useful Arts, by securing for limited Times to Authors and Inventors the exclusive Right to their respective Writings and Discoveries" (capitalization as in original). Although not apparent from first reading, "useful arts", "inventors" and "discoveries" are the words grating the authority for patents, and "science", "authors" and "writings" are the words granting the authority for copyrights. See EDWARD C. WALTERSCHEID, To Promote the Progress of Useful Arts: American Patent LaW AND ADMINISTRATION, 1793-836, at 19 (1998) ("[T] he intellectual property clause clearly encompassed two separate powers packaged together; one to promote the progress of science, i.e., knowledge, through the exclusive grant known as a copyright, and the other to promote the progress of useful arts through the exclusive grant known as a patent."). See also DONALD S. CHISUM, 1 CHISUM ON PATENTS OV-2, OV-3, 1-6, 1-7; R. CARL MOY, 1 MOY'S WALKER ON PATENTS $\S 1.11$ (4th ed.).

2135 U.S.C. $\S 101$ (2002) (emphasis added). For examples of 35 U.S.C.'s conditions and requirements, see 35 U.S.C. $\S 102$ (novelty), 103 (nonobvious subject matter) and 112 (specification).

${ }^{22}$ Kewanee Oil v. Bicron Corp., 416 U.S. 470, 483 (1974). Regardless of whether or not the claimed invention meets the other criteria for a patent, an individual cannot obtain a patent unless the invention "falls within one of the express categories of patentable subject matter of 35 U.S.C. $\S 101$ ”. Id.; see also Bilski v. Kappos, 130 S. Ct. 3218, 3225 (2010).

${ }^{23}$ Diamond v. Chakrabarty, 447 U.S. 303, 308 (1980). The Court in Chakrabarty noted that committee reports on the 1952 Patent Act informed the Court, "Congress intended statutory subject matter to "include anything under the sun that is made by 
consistently identified boundaries to patentable subject matter: "laws of nature", "physical" or "natural phenomena" 24 and "abstract ideas" are not patentable. ${ }^{25}$ Addressing these boundaries, Professor Eileen Kane has explained that " $[t]$ he underlying rationale for the exclusions is that scientific advances depend on an available substrate of basic knowledge, and that, therefore, patenting the intellectual foundations of a field has an adverse effect on its progress." ${ }^{26}$ As a result of these exclusions, what might otherwise fit within the statutory definitions of "process," "composition of matter," "manufacture," or "machine" is not patentable if the proposed patent effectively claims a law of nature, a physical phenomenon, or an abstract idea. ${ }^{27}$

man." 447 U.S. at 309 (quoting S. REP. NO. 82-1979, at 2399 (1952)). However, the Supreme Court clearly limited that general statement by the exclusions the Court repeated in Chakrabarty, that the laws of nature, physical phenomena, and abstract ideas are not patentable. $I d$. For additional views that the quote from the committee report was more limited, see Bilski, $130 \mathrm{~S}$. Ct. at 3248-49 (2010) (Stevens, J., concurring); Oskar Liivak, The Forgotten Originality Requirement: A Constitutional Hurdle for Gene Patents, 87 J. PAT. \& TRADEMARK OFF. SOC'Y 261, 279-281 (2005); 1 WALKER, supra note 20, §5:1, at 5-8 ("[W]hile both Congress and the courts have stated that the statutory language of section 101 encompasses 'anything under the sun that is made by man,' . . this is decidedly not the case. Instead, the authorities have agreed that certain types of activity are non-statutory subject matter, even where the particular subject matter at hand could be described nominally in the terms of section 101 as, for example, a process or an article of manufacture.").

${ }^{24}$ See Bilski, $130 \mathrm{~S}$. Ct. at 3225 (referring to the three exceptions to patentable subject matter under $\S 101$ as "laws of nature, physical phenomena and abstract ideas.") In Diamond v. Diehr, 450 U.S. 175, 185 (1981), the Court referred to "natural phenomena" as unpatentable; in Gottschalk v. Benson, 409 U.S. 63, 67 (1972), the Court referred to "Phenomena of nature" as unpatentable; and in Parker v. Flook, 437 U.S. 584, 589 (1978), the Court referred to "Phenomena of nature" as unpatentable. The Court has used those terms - physical phenomena and natural phenomena-interchangeably. This article generally uses "physical phenomena" instead of "natural phenomena," to try to better distinguish between physical matter found in nature (physical phenomena) and relationships inherent in nature (laws of nature), although frequently the lines are not clear.

${ }^{25}$ Chakrabarty, 447 U.S. at 309 (citing Parker, 437 U.S. at 584; Gottschalk, 409 U.S. at 67; Funk Bros. Seed Co. v. Kalo Inoculant Co., 333 U.S. 127, 130 (1948); O'Reilly v. Morse, 56 U.S. (15 How.) 62, 112-21 (1854); Le Roy v. Tatham, 55 U.S. (14 How.) 156, 175 (1852)).

${ }^{26}$ Eileen M. Kane, Patenting Genes and Genetic Methods: What's At Stake?, 6 J. BUS. \& TECH. L. 1, 4-5 (2011).

${ }^{27}$ See Bilski, 130 S. Ct. at 3226 ("Any suggestion in this Court's case law that the Patent Act's terms deviate from their ordinary meaning has only been an explanation for the exceptions for laws of nature, physical phenomena, and abstract ideas."). In Bilski, the Supreme Court limited the meaning of "process" to avoid the 
Of course, nothing made by humans can flout laws of nature, and all physical objects must be derived in part from products found in nature. ${ }^{28}$ However, humans did not invent laws of nature or physical phenomena, so these are not "new." ${ }^{29}$ Courts must draw lines for determining the difference between (1) unpatentable laws of nature or physical phenomena and (2) patentable applications of those unpatentable elements. ${ }^{30}$

In its 2012 decision in Myriad Genetics, the Federal Circuit said, without reference to any research or Supreme Court precedents supporting its view, that "patents on life-saving material and processes, involving large amounts of risky investment, would seem to be precisely the types of subject matter that should be subject to the incentives of exclusive rights.",31 Yet scientists provided empirical evidence to the U.S. Government in 2010 that patents on basic genetic discoveries had not increased basic genetic research and had probably harmed the availability of genetic testing. ${ }^{32}$ Legal scholars have likewise argued that the aggressive patenting of basic research encouraged by federal legislation and case law did not in fact further the

issuance of a patent for an abstract idea. Id. at 3229-31. This article focuses on laws of nature and physical phenomena rather than abstract ideas, since those are the exclusions applicable to patents for isolated DNA segments.

${ }^{28}$ See Mayo Collaborative Servs. v. Prometheus Labs., Inc., 132 S. Ct. 1289, 1293 (2012) ("For all inventions at some level embody, use, reflect, rest upon, or apply laws of nature, natural phenomena, or abstract ideas."); RoBIN FELDMAN, RETHINKING PATENT LAW 96 (2012) ("All inventions to some extent rely on and use laws of nature, laws of physics, and other natural phenomena."); Parasidis, supra note 16 , at 327.

${ }^{29}$ See infra Part II.C. The basis for and the application of the abstract ideas exclusion to many cases and different fact situations is beyond the scope of this article, although this article discusses some Supreme Court cases on abstract ideas, because they shed light on the importance the Supreme Court has placed on the exclusions from patentable subject matter.

${ }^{30}$ See, e.g., Prometheus, 132 S. Ct. at 1293-94 ("[A]n application of a law of nature or mathematical formula to a known structure or process may well be deserving of patent protection." (emphasis omitted) (quoting Diamond v. Diehr, 450 U.S. 175, $187(1981)))$.

${ }^{31}$ Assoc. for Molecular Pathology v. Myriad Genetics, Inc., 689 F.3d 1303, 1324 (Fed. Cir. 2012).

${ }^{32}$ Report of the Secretary's Advisory Committee on Genetics, Health and Society, Gene Patents and Licensing Practices and Their Impact on Patient Access to Genetic Tests, OfFICE OF BIOTECHNOLOGy ACTIVITIES (April 2010), available at http://oba.od.nih.gov/oba/sacghs/reports/SACGHS_patents_report_2010.pdf. The Roster and Ex Officio Members of SACGHS are listed at pp. i-iv. Specifically, the Chair of the SACGHS Report concluded, "The substantial number of existing patents on genes and methods of diagnosis also pose a threat to the development of multiplex testing, parallel sequencing, and whole-genomic sequencing, the areas of genetic testing with the greatest potential future benefits." Id. at cover letter. 
economic goal of developing new products. ${ }^{33}$ Furthermore, some economists have argued that intellectual property laws, including patent law, "does not increase either innovation or creation. They are an unnecessary evil.," ${ }^{34}$ At a minimum, there is controversy over the effect of patents on innovation in basic research. ${ }^{35}$

The statute on subject matter patentability, however, has remained strikingly similar since 1790 . Since 1793 , the statute has required that in order to be patentable, the claimant must have "invented a new and useful

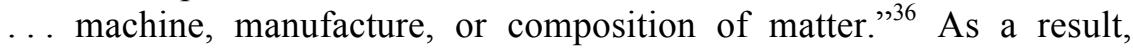

${ }^{33}$ Arti Kaur Rai, Regulating Scientific Research: Intellectual Property Rights And The Norms Of Science, 94 Nw. U. L. REV. 77, 115 (1999). Professor Rai was referring particularly to the Bayh-Dole Act codified as 35 U.S.C. $\S \S 200-212$, Chakrabarty, and Diehr.

${ }^{34}$ Michelle Boldrin \& David K. Levine, Against InTELlectual Monopoly 7 (2010). Boldrin and Levine do not argue for the immediate elimination of intellectual property laws, acknowledging that "a sudden elimination of intellectual property laws may bring about collateral damages of an intolerable magnitude ... [A]bolition must be approached by smaller steps ...." Id. at 244-45. With respect to pharmaceutical innovation, they argue that, "[f]ar from encouraging great new health and life-saving products, the [patent] system instead produces too much innovation and expense of the wrong kind - me-too drugs to get around the other guy's patents and get a share of a lucrative market ...." Id. at 238. On the other hand, there is much scholarly support for the proposition that patents increase innovation. See, e.g., 1 MoY, supra note 20 , at $\S 1: 39,1-82$ ("The favored explanation for the patent system in the United States is that it creates an incentive for persons to engage in inventive activity."); Edmund W. Kitch, The Nature and Function of the Patent System, 20 J.L. \& ECON. 265 (1977).

35 See, e.g., Stephen A. HANSEN et al., American Assoc. for the AdVANCEMENT of SCIENCE, INTElleCtual Property EXPERIENCES IN THE UNITED STATES SCIENTIFIC COMMUNITY 7 (2007), available at http://sippi.aaas.org/Pubs/SIPPI_US_IP_Survey.pdf; ROBERT P. MERGES, JUSTIFYING INTELLECTUAL PROPERTY 3 (2011) ("I simply cannot justify our current IP [both copyright and patent] system on the basis of verifiable data showing that people are better off with IP law than they would be without it."); Rebecca S. Eisenberg, Noncompliance, Nonenforcement, Nonproblem? Rethinking the Anticommons in Biomedical Research, 45 Hous. L. REV. 1059, 1098 (2008) (reviewing various empirical studies and concluding that "[s]urvey results from scientists suggest that, although commercial scientists face more obstacles from intellectual property than academic scientists, in both settings it is rare for an ongoing project to be stopped because of patents .... On the other hand, scientists in both academic and commercial laboratories report more problems in gaining access to 'practically excludable' resources such as tangible materials and data that they cannot readily duplicate in their own laboratories.").

${ }^{36}$ Section 1 of the Patent Act of 1790 provided for the grant of a patent to "any person or persons ... [who] hath or have invented or discovered any useful art, manufacture, engine, machine, or device, or any improvement therein not before 
Supreme Court cases from the 1800s and 1900s interpreting the predecessor to current $\S 101$ remain important today, especially in light of the common law tradition of interpreting patentable subject matter. ${ }^{37}$

\section{B. Supreme Court Decisions Prior to Chakrabarty}

In the nineteenth century, the Supreme Court examined what must be free from patents for all to use. In LeRoy v. Tatham, the Court held, "[a] principle, in the abstract, is a fundamental truth; an original cause; a motive;

known or used .... if they [any two of the Secretary of State, Secretary of the Department of War and Attorney General] shall deem the invention or discovery sufficiently useful and important ...."9 CHISUM, supra note 20, at App. 9-1. Section 1 of the Patent Act of 1793 provided for the grant of a patent to any person(s) who "have invented any new and useful art, machine, manufacture or composition of matter, or any new and useful improvement on any art, machine manufacture or composition of matter, not known or used before the application ...." The 1793 Patent Act, however, eliminated the requirement that the invention be deemed "sufficiently useful and important." Id., App. 10-1; 1 ChISUM, supra note 20, at OV-3. Section 6 of the Patent Act of 1836 provided for a patent to "any person or persons having discovered or invented any new and useful art, machine, manufacture, or composition of matter, or any new and useful improvement on any art, machine, manufacture or composition of matter, not known or used by others before his or their discovery of invention thereof ...." 9 ChISUM, supra note 20, at App. 11-3. Section 24 of the Patent Act of 1870 had essentially identical language on the basic requirements, although there were other modifications to the requirements. The requirement of "invent" "new" and "useful" was continued in the Patent Act of 1952, although that Act substituted "process" for “art." Id. at App. 19-7. 35 U.S.C. § 100(b) defines "process" to mean "process, art or method, and includes a new use of a known process, machine, manufacture, composition of matter, or material."

${ }^{37}$ Cf. Peter S. Menell, Forty Years Of Wandering In The Wilderness And No Closer To The Promised Land: Bilski's Superficial Textualism And The Missed Opportunity To Return Patent Law To Its Technology Mooring, 63 STAN. L. REV. 1289,1314 (2011) ("'P]atentable subject matter cannot evolve to meet the new challenges of the new information age without integrating eighteenth-, nineteenth-, and twentieth-century sources of patentable subject matter into a flexible and evolving body of common law that is sensitive to history, statutory evolution, constitutional constraints, and understanding of modern science and technology. This will be particularly important as courts confront the patentability of DNA compounds, diagnostic tests and unforeseeable information age innovations."); Craig Allen Nard, Legal Forms And The Common Law Of Patents, 90 B.U. L. REV. $51,53,108$ (2010) ("[T] he patent code, much like the Sherman Act, is a common law enabling statute .... For more than two hundred years the courts have navigated the contours of the patent system, adeptly construing doctrine and interpreting elliptical statutory phrases ... This accretive process . . . possesses comparative advantages to congressional enactments."). 
these cannot be patented ....,38 In $O^{\prime}$ Reilly v. Morse, the Court explained its rejection of Morse's claim to electro-magnetism with the following analogy: "No one, we suppose, will maintain that Fulton could have taken out a patent for his invention of propelling vessels by steam, describing the process and machinery he used, and claimed under it the exclusive right to use the motive power of the steam. ${ }^{, 39}$ In American Wood Paper Co. v. Fibre Disintegrating Co., the Supreme Court rejected a patent for cellulose "isolated" from nature and held that "the manufacture claimed as novel is not a new composition of matter, but an extract obtained by the decomposition or disintegration of material substances." ${ }^{40}$ Finally, in Cochrane v. Badische Anlin \& Soda Farik, the Supreme Court rejected a patent for a synthetically made dye, alizarine, that had previously been made by isolating dye from the root of the madder plant, characterizing the claimed invention as "an old article" and noting that "[c]alling it artificial alizarine did not make it a new composition of matter, and patentable."

What do these nineteenth century cases suggest? The Court has long recognized that patents could not issue for fundamental principles or truths ${ }^{42}$ or products that existed in nature. ${ }^{43}$ Further, simply claiming what nature does is not patentable. ${ }^{44}$ While the Court established no clear formula

${ }^{38}$ Le Roy v. Tatham, 55 U.S. 156, 175 (1852). Tatham involved a patent for machinery for making pipes and tubes from metallic substances. Id. at 156.

${ }^{39}$ O'Reilly v. Morse, 56 U.S. 62, 112-13 (1853). The Court upheld Samuel Morse's invention of the telegraph, but rejected as "too broad" his eighth claim for the "use of the motive power of the electric or galvanic current, which I call electro-magnetism, however developed for marking or printing intelligible characters, signs, or letters, at any distances ...." Id.

${ }^{40}$ Am. Wood Paper Co. v. Fibre Disintegrating Co., 90 U.S. 566, 593, 596 (1874). The case specifically involved "a pulp suitable for the manufacture of paper, made from wood or other vegetable substances, by boiling the wood or other vegetable substance in ... alkali." Id. at 577. It is apparent that the structure of the wood pulp claimed was different than the structure of cellulose found in nature. There separately was a process claim at issue. Id. at 593, 596-97. The Court said, "It is insisted ... that the paper-pulp which had been produced before ... was not pure cellulose, ... and from this it is argued that the pure article obtained from wood by [the inventor's] . . process is a different and new product, or manufacture." Id. at 594. Whether or not the wood pulp produced by the patentee in fact was pure cellulose, the Court proceeded on the assumption it was. Id. at 596.

${ }^{41}$ Cochrane v. Badische, 111 U.S. 293, 311 (1884). FeldMAN, supra note 28, at $328 \mathrm{n} .193$, refers to this view of the case as "effectively dictum." This is incorrect, however, because the Court did not choose between the two views of the case expressed in the opinion, but concluded, "In either view the decree of the circuit court must be reversed ...." Cochrane, 111 U.S. at 313.

${ }^{42}$ Tatham, 55 U.S. at 175.

${ }^{43}$ Am. Wood Paper, 90 U.S. at 593, 596.

${ }^{44}$ The eighth claim in O'Reilly v. Morse, 56 U.S. 62, 112-13 (1853). 
for determining patent eligibility, the mere fact that humans synthetically made a product ${ }^{45}$ or isolated it from nature ${ }^{46}$ did not guarantee that the product constituted patentable subject matter. Instead, there must be different characteristics and uses in the claimed product than existed with the natural product. ${ }^{47}$

The Supreme Court cases in the twentieth century continued to recognize these limits on patentable subject matter when the patent claims focused on laws of nature or products found in nature. For instance, the Supreme Court rejected in American Fruit Growers, Inc. v. Brogdex Co. a patent for "[f]resh citrus fruit of which the rind or skin carries borax in amount ... sufficient to render the fruit resistant to blue mold decay." Supreme Court explained, "There is no change in the name, appearance, or general character of the fruit. It remains a fresh orange, fit only for the same beneficial uses as theretofore." 49

In 1948, the Supreme Court invalidated in Funk Brothers Seed Co. v. Kalo Inoculant Co. a patent for a combination of bacteria for leguminous plants mixed in a powder or liquid base and packaged for sale. ${ }^{50}$ Different bacteria promoted growth in different legumes, but when mixed together, the experience had been that the different bacteria inhibited the positive growth effects of each other on the legumes. ${ }^{51}$ The inventor had discovered that certain bacteria could be mixed together without the inhibiting effect, and so he sold to the public packages containing a mixture of certain bacteria (presumably a mixture not found in nature) for use with different species of legumes. ${ }^{52}$ The Court held that the inventor "does not create state of inhibition or of non-inhibition in the bacteria ... [and] patents cannot

${ }^{45}$ Cochrane, 111 U.S. at 311.

${ }^{46}$ Am. Wood Paper, 90 U.S. at 593, 596.

${ }^{47}$ Id.

${ }^{48}$ Am. Fruit Growers, Inc. v. Brogdex Co., 283 U.S. 1, 6 (1931).

${ }^{49}$ Id. at 11-12. See Kane, supra note 26, at 13 ("[T] he Supreme Court decided that the addition of borax to the rind of an orange to increase its longevity did not confer a patentable distinction, when compared to an unadulterated orange, to create an article of manufacture ....”).

${ }^{50}$ Funk Bros. Seed Co. v. Kalo Inoculant Co., 333 U.S. 127, 129, 132 (1948). The issue in Funk Bros. was not "whether the methods of selecting and testing the noninhibitive strains are patentable." Id. at 130 (emphasis added). The case concerned only product claims. What the Court described as illustrative was the following claim: "An inoculant for leguminous plants comprising a plurality of selected mutually non-inhibitive strains of different species of bacteria of the genus Rhizobium, said strains being unaffected by each other in respect to their ability to fix nitrogen in the leguminous plant for which they are specific." $I d$. at 127 n.1.

${ }^{51} \mathrm{Id}$. at 129.

${ }^{52} \mathrm{Id}$. 
issue for the discovery of the phenomena of nature." ${ }^{, 53}$ The Court added that "[t]he qualities of those bacteria, like the heat of the sun, electricity, or the qualities of metals, are part of the storehouse of knowledge of all men ... manifestations of laws of nature, free to all men and reserved exclusively to none." 54 The mixing of the bacteria in a powder or liquid base thus did not render the bacteria patentable.

In 1966, in Graham v. John Deere Co. of Kansas City, ${ }^{55}$ a case involving a patent for an improvement in a clamp for plows, the Supreme Court again emphasized, "Congress may not authorize the issuance of patents whose effects are to remove existent knowledge from the public domain, or to restrict free access to materials already available." ${ }^{, 6}$ It cautioned that " $[t]$ his is the standard expressed in the Constitution and it may not be ignored." ${ }^{, 7}$

In the fifteen years after Graham, the Court restated in a number of cases the same principle - patents cannot remove from the public domain information and material already available to the public. For instance, in 1972, in Gottschalkv. Benson, ${ }^{58}$ the Supreme Court said that "[p]henomena of nature, though just discovered, mental processes, and abstract intellectual concepts are not patentable, as they are the basic tools of scientific and technological work. ${ }^{, 59}$ In 1978, the Supreme Court held in Parker v. Flook ${ }^{60}$

${ }^{53} I d$. at 130.

${ }^{54}$ Id. For a discussion of conflicting interpretations of Funk Brothers, see John M. Conley \& Robert Makowski, Back to the Future: Rethinking the Product of Nature Doctrine as a Barrier to Biotechnology Patents (Part II), 85 J. PAT. \& TRADEMARK OFF. SOC'Y 301, 330-34 (2003). Professor Conley and Dr. Makowski conclude that "[a] fairer characterization of the holding is that Bond failed because his real and only discovery was the product of nature, which he applied in only the most obvious way possible: exactly as he found it. In other words, his patent was denied because his purported 'application' was not materially distinguishable from the work of nature." Id. at 334.

${ }^{55}$ Graham v. John Deere Co. of Kansas City, 383 U.S. 1 (1966).

${ }^{56}$ Id. at 6 . The Court was not considering the three exemptions from patentable subject matter in Graham, but this statement of a "non-removal" principle is a compelling rationale for the exclusions of laws of nature and physical phenomena from patentable subject matter.

${ }^{57} I d$. Allen Yu argues that "subject matter eligibility is more than just a substantive patentability requirement, it is fundamentally a constitutional requirement touching upon the very existential reasons for having a patent system." Yu, supra note 15, at 425.

${ }^{58}$ Gottschalk v. Benson, 409 U.S. 63 (1972).

${ }^{59} \mathrm{Id}$. at 67 . As set forth above in notes 29-30 and accompanying text, it is easy to understand that physical phenomena and natural laws are not new, although humans may only recently have discovered them. It may be more difficult to categorize certain abstract ideas as previously available to the public. As mentioned in note 27, supra, a detailed analysis of the relationship between the abstract ideas exclusion 
that a patent using an algorithm to adjust alarm limits during catalytic conversion - without the addition of an inventive concept- - was invalid. ${ }^{61}$ As the Court explained, "Even though a phenomenon of nature or mathematical formula may be well known, an inventive application of the principle may be patented. Conversely, the discovery of such a phenomenon cannot support a patent unless there is some other inventive concept in its application." ${ }^{62}$

American Fruit Growers, Funk Brothers, Graham, Gottschalk, and Flook exclude from patentable subject matter products and fundamental principles that exist in nature, whether or not humans had discovered them before the claimed invention. Further, mere practical applications of such principles cannot transform unpatentable truths into patentable subject matter. American Fruit Growers and Funk Brothers also support the principle that, in determining whether a composition constitutes patentable subject matter, a court must consider not only whether the specific composition is found in nature, but also whether the human intervention significantly changed the functioning of the composition.

\section{Chakrabarty, Diehr, and Bilski}

In Chakrabarty, the Supreme Court first addressed whether living matter (specifically, living matter created by inserting at least two plasmids into the cell of a bacteria to significantly change the functioning of the bacteria) constituted patentable subject matter under $\S 101 .^{63}$ The sole

and $\S 101$ is beyond the scope of this article, since the composition claims of Myriad Genetics do not raise the issue of abstract ideas.

${ }^{60}$ Parker v. Flook, 437 U.S. 584 (1978).

${ }^{61}$ Id. at $590-94$.

${ }^{62}$ Id. at 594 (emphasis added). Earlier in the opinion, the Court said, "[w] hether the algorithm was in fact known or unknown at the time of the claimed invention, as one of the 'basic tools of scientific and technological work' ... it is treated as though it were a familiar part of the prior art." Id. (quoting Gottschalk, 409 U.S. at 67). This phrase, "treated as though it were a familiar part of the prior art," has provoked controversy - apart from the holding in the case.

63 Diamond v. Chakrabarty, 447 U.S. 303, 305 (1980) ("We granted certiorari to determine whether a live, human-made micro-organism is patentable subject matter ...."). Of course, the humans did not create the life in the bacteria or the plasmids, but inserted living plasmids into living bacteria. The Supreme Court explained, "Plasmids are hereditary units physically separate from the chromosomes of the cell. In prior research, Chakrabarty and an associate discovered that plasmids control the oil degradation abilities of certain bacteria. In particular, the two researchers discovered plasmids capable of degrading camphor and octane, two components of crude oil. In the work represented by the patent application at issue here, Chakrabarty discovered a process by which four different plasmids, capable of degrading four different oil components, could be transferred to and maintained 
issue in Chakrabarty was whether the enhanced bacteria constituted patentable subject matter under $\S 101 .^{64}$ To resolve the issue, the Court noted that it must determine whether the micro-organism constitutes a manufacture or composition of matter. ${ }^{65}$ Though the Court first adopted broad definitions of "manufacture" 66 and "composition of matter,", it also recognized that laws of nature, physical phenomena, and abstract ideas are excluded from patentable subject matter. ${ }^{68}$

In a 5-4 decision, the Supreme Court held that "the patentee has produced a new bacterium with markedly different characteristics from any found in nature and one having the potential for significant utility. His discovery is not nature's handiwork, but his own; accordingly it is patentable subject matter under $\S 101 .{ }^{\prime 69}$ The Court explained that the plasmid-enhanced bacteria were capable of degrading multiple components of crude oil, a use possessed by no naturally occurring bacteria, and therefore had significant value for the treatment of oil spills. ${ }^{70}$

As in American Wood Paper, American Fruit Growers, and Funk Bros., the Court in Chakrabarty compared (1) the physical characteristics of the invention to what had been found in nature (the plasmid-enhanced bacteria compared to natural bacterium) and (2) the functioning of the invention to what had been found in nature (the plasmid-enhanced bacteria did degrade crude oil, whereas natural bacteria did not). ${ }^{71}$ The Court said

stably in a single Pseudomonas bacterium, which itself has no capacity for degrading oil." $I d$. at 305 n.1.

${ }^{64} \mathrm{Id}$.

${ }^{65} \mathrm{Id}$. at 307. Finding patentable subject matter, the Court did not state whether the bacteria was a manufacture or a composition of matter. Id. at 307-09.

${ }^{66} \mathrm{Id}$. at 308 (quoting Am. Fruit Growers, 283 U.S. at 11).

${ }^{67}$ Id. (quoting Shell Dev. Co. v. Watson, 149 F. Supp. 279, 280 (D.D.C.1957)).

${ }^{68}$ Id. at 309 (citing Parker v. Flook, 437 U.S. 584 (1978); Gottschalk v. Benson, 409 U.S. 63, 67 (1972); Funk Bros. Seed Co. v. Kalo Inoculant Co., 333 U.S. 127, 130 (1948); O’Reilly v. Morse, 56 U.S. (15 How.) 62, 112-21 (1853); Le Roy v. Tatham, 56 U.S. (15 How.) 156, 175 (1852)).

${ }^{69}$ Chakrabarty, 447 U.S. at 310 (emphasis added). The Court did not discuss a standard for determining "markedly different."

${ }^{70}$ Id. at 304. Professor Rai observed that Chakrabarty "heralded a more favorable attitude towards patents" and that subsequently the Federal Circuit significantly strengthened patent rights. See Rai, supra note 33, at 101.

${ }^{71}$ For a detailed discussion of Chakrabarty, see John M. Conley \& Roberte Makowski, Back To The Future: Rethinking The Product Of Nature Doctrine As A Barrier To Biotechnology Patents (Part II), 85 J. PAT. \& TRADEMARK OFF. SOC'Y 301, 371-76 (April 2003). Professor Conley and Dr. Makowski state that it is clear in Chakrabarty that the Court considered Funk Brothers good law. Id. at 376. They also wrote that the "principal distinction" between Funk Brothers and Chakrabarty "appears to be that the Funk inventor did his work by mixing cells, whereas 
that the relevant distinction "was not between living and inanimate things, but between products of nature, whether living or not, and human-made inventions." ${ }^{, 72}$ The Court did not address the standard for determining patentable subject matter, which tests (a) if humans had subtracted elements from a product found in nature, or (b) if humans had created a synthetic copy of what existed in nature. ${ }^{73}$

Just a year later, in Diamond v. Diehr ${ }^{74}$ the Supreme Court upheld a patent that was drawn to applications of an unpatentable formula in an industrial setting. ${ }^{75}$ The Court declared, "While a scientific truth, or the mathematical expression of it, is not a patentable invention, a novel and useful structure created with the aid of knowledge of scientific truth may be, ${ }^{, 76}$ when it transforms an article to a different state or thing. ${ }^{77}$ The Court held the patent constituted patentable subject matter because it did not view the claims as an attempt to patent a mathematical formula but rather to cover an industrial process in molding rubber products. ${ }^{78}$

In 2010, the Supreme Court in Bilski rejected a process "for instructing buyers and sellers how to protect against the risk of price fluctuations in a discrete section of the economy." 79 The Court repeated the principles established in Chakrabarty and Funk Brothers that "laws of nature, physical phenomena, and abstract ideas" are "part of the storehouse of knowledge of all men ... free to all men and reserved exclusively to

Chakrabarty had to introduce new genetic material within a cell." Id. Although that explains the difference in the comparison of chemical compositions, the Supreme Court clearly considered the additional function of the plasmid-enhanced bacteria as a significant distinction from the natural bacteria.

${ }^{72}$ Chakrabarty, 447 U.S. at 313. Subsequently in J.E.M. Ag. Supply v. Pioneer HiBred Int'l, Inc., the Supreme Court confirmed that the distinction the Court considered crucial under $\S 101$ was between "products of nature, whether living or not, and human-made inventions," and held that the Plant Variety Protection Act and the Plant Patent Act of 1930 were not the exclusive means of obtaining a patent for human-developed plant breeds. 534 U.S. 124, 130 (2001) (quoting Chakrabarty, 447 U.S. at 313).

${ }_{74}^{73}$ See supra note 40 and accompanying text.

${ }^{75}$ Diamond v. Diehr, 450 U.S. 175 (1981).

${ }^{75} \mathrm{Id}$.

${ }^{76}$ Id. at 188 (internal quotation marks omitted).

${ }^{77} \mathrm{Id}$. at 192.

${ }^{78}$ Id. at 192-93. For a criticism of the Court's decision in Diehr, see Sarnoff, supra note 15, at 77 ("Diehr, like Benson, thus imposed needless confusion by permitting the creativity of the ineligible discovery to contribute directly to the eligibility of a claimed application without considering whether there was any additional creativity in the application itself.").

${ }^{79}$ Bilski v. Kappos, 130 S. Ct. 3218, 3223 (2010). 
none. ${ }^{~} 80$ The Court then emphasized that these exceptions were consistent with the requirement that to be patentable, a process must be "new and useful." ${ }^{81}$ As Professors Demaine and Fellmeth have pointed out, "By its plain terms, the requirement that an invention be 'new' requires that the claimed product or process must not have previously existed in nature." ${ }^{, 82}$

In his concurring opinion in Bilski, ${ }^{83}$ Justice Breyer stated that he summarized the views of all the Justices when noting the Court has long held "[p]henomena of nature, though just discovered, mental processes, and abstract intellectual concepts are not patentable" under $\S 101 .{ }^{84} \mathrm{He}$ further emphasized that "allowing individuals to patent these fundamental principles would "wholly pre-empt" the public's access to the "basic tools of scientific and technological work." 85 Justice Breyer likewise observed that " $[\mathrm{t}]$ he Court has thus been careful in interpreting the Patent Act to 'determine not only what is protected, but also what is free for all to use.","86

The following section examines in detail the Supreme Court's next decision on patentable subject matter, Prometheus. This unanimous decision sets forth further guidance on what is free for all to use and should guide the outcome in Myriad Genetics.

\section{Prometheus}

\section{Background}

Prometheus centered on the validity of patents for diagnosing the use of thiopurine drugs in the treatment of certain diseases. ${ }^{87}$ The legal issue

${ }^{80}$ Id. at 3225 (quoting Diamond v. Chakrabarty, 447 U.S. 303, 309 (1980); Funk Bros. Seed Co. v. Kalo Inoculant Co., 333 U.S. 127, 130 (1948)).

${ }^{81} I d$. at 3225 .

${ }^{82}$ Linda J. Demaine \& Aaron Xavier Fellmeth, Reinventing the Double Helix: a Novel and Nonobvious Reconceptualization of the Biotechnology Patent, 55 STAN. L. REV. 303, 386 (2002). See Part II.C, infra, for further discussion of "new" in $\S 101$.

${ }^{83}$ Justice Scalia concurred in the part of Justice Breyer's opinion discussed in this paragraph.

${ }^{84}$ Bilski, 130 S. Ct. at 3258 (Breyer, J., concurring) (alteration in original) (quoting Gottschalk v. Benson, 409 U.S. 63, 67 (1972)).

${ }^{85}$ Id. (quoting Gottschalk, 409 U.S. at 67).

${ }^{86} I d$. at 3258 (quoting Bonito Boats, Inc. v. Thunder Craft Boats, Inc., 489 U.S. 141, 151 (1989)).

${ }^{88}$ Mayo Collaborative Servs. v. Prometheus Labs., Inc., 132 S. Ct. 1289, 1294-96 (2012). The representative claim quoted by the Court was the following claim 1 of U.S. Patent No. 6,355,623 ('623 Patent): “A method of optimizing therapeutic efficacy for treatment of an immune-mediated gastrointestinal disorder, comprising: (a) administering a drug providing 6-thioguanine to a subject having said immunemediated gastrointestinal disorder; and (b) determining the level of 6-thioguanine 
revolved around the inherent reaction of human bodies to synthetic chemicals inserted into the body. Scientists had known that the levels of certain metabolites ${ }^{88}$ of thiopurine drugs were correlated to the effectiveness or harm of the drug in individuals, but they had not known the precise correlations. ${ }^{89}$ Prometheus's patent claims "identified these correlations with some precision" and added that the result of the process indicated a need to decrease (or increase) the level of thiopurine drug administered. ${ }^{90}$ Given this, a doctor using the Mayo Collaborative Services test (a slightly different test than specified by the patent) could violate the patent even if she did not actually alter her treatment decision. ${ }^{91}$

Confirming its precedents, the Supreme Court cited five of its earlier decisions going back to 1854 as the foundation for its statement that "'laws of nature, natural phenomena, and abstract ideas' are not patentable." ${ }^{\prime 2}$ The Court likewise reiterated that such subjects were not

in said subject having said immune-mediated gastrointestinal disorder, wherein the level of 6-thioguanine less than about $230 \mathrm{pmol}$ per $8 \times 10^{8}$ red blood cells indicates a need to increase the amount of said drug subsequently administered to said subject and wherein the level of 6-thioguanine greater than about 400 pmol per $8 \times 10$ red blood cells indicates a need to decrease the amount of said drug subsequently administered to said subject." Id. at 1295 (citation omitted). The claim used the word "method," but the Court used "process" to describe the claim at issue. $I d$. The Supreme Court noted, "[ $[$ ] he District Court found that Mayo's test infringed claim 7 of the ' 623 patent. ... The number Mayo used (450) was too close to the number the claim used (400) to matter given appropriate margins of error." Id. at 1296 (citation omitted).

88 "Metabolism" is the "sum total of biochemical reactions carried out by an organism." H. ROBERT HORTON ET AL., PRINCIPLES OF BIOCHEMISTRY 819 (4th ed. 2006) [hereinafter BIOCHEMISTRY]. A "metabolite" is an "intermediate in the synthesis of degradation of biopolymers and their component units." Id. A "biopolymer" is a "biological macromolecule in which many identical or similar small molecules are covalently linked to one another to form a long chain. Proteins, polysaccharides, and nucleic acids are biopolymers." $I d$. at 812 .

89 Prometheus, $132 \mathrm{~S}$. Ct. at 1295 . The Court also noted that individuals metabolized thiopurine drugs differently.

${ }^{90} I d$.

${ }^{91}$ Id. at 1296. Prometheus was not the inventor, but the "sole and exclusive licensee of the patents" who sold "diagnostic tests that embody the processes the patents describe." Id. at 1295. Prometheus sued Mayo Collaborative Services for administering a test using a slightly different correlation. See supra note 87.

${ }^{92}$ Id. at 1293 (citing Bilski v. Kappos, 130 S. Ct. 3218, 3233-34 (2010); Diamond v. Chakrabarty, 447 U.S. 303, 309 (1980); Le Roy v. Tatham, 55 U.S. (14 How.) 156, 175 (1852); O'Reilly v. Morse, 56 U.S. (15 How.) 62, 112-20 (1853)). The Supreme Court also cited Neilson v. Harford, Webster's Patent Cases 295, 371 (1841) (an English patent case). Diehr, Bilski, and Harford involved process claims, whereas Chakrabarty and Tatham involved product claims. Morse involved both product and process claims. Except for the earlier Federal Circuit decisions in 
patentable, as they formed the basis for scientific and technological research. ${ }^{93}$ The Court also repeated the refrain that "monopolization of those tools through the grant of a patent might tend to impede innovation more than it would tend to promote it." 94

The Supreme Court in Prometheus recognized a continuum from unpatentable laws of nature to patentable applications, observing that "[w] hile a scientific truth, or the mathematical expression of it, is not a patentable invention, a novel and useful structure created with the aid of knowledge of scientific truth may be." 95 The Court cautioned, however, that in order to be patentable, "one must do more than simply state the law of nature while adding the words 'apply it.",96

The Supreme Court listed the following considerations for interpreting the validity of patent applications that focus on a law of nature:

- Is the claim simply a draftsman's trick to circumvent the prohibition against patenting laws of nature $;^{97}$

- Would the claim-if approved-"too broadly preempt" a law of nature ${ }^{98}$

- Does the claim have an element evidencing an "inventive concept" beyond the law of nature $;{ }^{99}$ and

- Is any element in addition to the law of nature simply an attempt to limit the use of the law of nature to a particular technological environment or insignificant activity after determining how the law of nature

Prometheus, the Court did not cite a single Federal Circuit case as precedent. The Prometheus Court referred to these four items as an "important implicit exception" to 35 U.S.C. $\$ 101$. Prometheus, 132 S. Ct. at 1293 . Since the statutory requirement that claimed subject matter must have been invented by the applicant and must be new (see II-B and C of this article) is fully consistent with the law of nature and phenomena of nature "exclusion," this article refers to these principles as exclusions rather than exceptions. Whether the "abstract idea" exception is also inherently a part of the language of $\S 101$ is a separate question beyond the scope of this article.

${ }^{93} I d$.

${ }^{94} \mathrm{Id}$.

${ }^{95}$ Id. at 1294 (quoting Diehr, 450 U.S. at 188 (1981)) (citations omitted). It also said, "all inventions at some level embody, use, reflect, rest upon, or apply laws of nature, natural phenomena or abstract ideas." Id. at 1293.

${ }^{96} I d$. at 1294 (citing Gottschalk v. Benson, 409 U.S. 63, 71-72 (1972)).

${ }^{97}$ Id. (citing Parker v. Flook, 437 U.S. 584, 593 (1978)).

${ }^{98}$ Id. (citing O'Reilly v. Morse, 56 U.S. at 112-20; Benson, 409 U.S. at 71-72).

${ }^{99}$ Id. (quoting Flook, 437 U.S. at 594). The Court used the word "inventive" five times. See id. at 1294, 1299, 1300, 1305. 
applied in the situation described. ${ }^{100}$

The Court found ${ }^{101}$ that: (1) the steps in the processes at issue (apart from the natural laws themselves) "involve well-understood, routine, conventional activity previously engaged in by researchers in the field.",102 and (2) "the patents would risk disproportionately tying up the use of the underlying natural laws, inhibiting their use in the making of further discoveries." $" 103$

\section{Holding in Prometheus}

Part II of the Court's decision started by identifying the law of nature covered by the claim: the "relationships between concentrations of certain metabolites in the blood and the likelihood that a dosage of a thiopurine drug will prove ineffective or cause harm." ${ }^{\text {"104 }}$ The Court then

${ }^{100} I d$. at 1294 (citing Bilski v. Kappos, 130 S. Ct. 3218, 3230 (2010); Diehr, 450 U.S. at 191-92).

${ }^{101}$ The Court said, "[w]e find that the process claims at issue here do not satisfy these conditions." Id. It is apparent the Court was referring there to a legal finding or conclusion, rather than a finding of fact. Patentable subject matter is a question of law, subject to underlying factual questions. See In re Comiskey, 554 F.3d 967, 975 (Fed. Cir. 2009); Arrhythmia Research Tech., Inc. v. Corazonix Corp., 958 F.2d 1053, 1055-56 (Fed. Cir. 1992).

${ }^{102}$ Prometheus, 132 S. Ct. at 1294.

${ }^{103} \mathrm{Id}$.

${ }^{104}$ Id. at 1296. The conclusion that the correlation is a law of nature has not gone unchallenged. See, e.g., Denise DeFranco, Mayo, A Force to Be Reckoned With, 4 LANDSLIDE, 24, 24, 27 (July-Aug. 2012) ("Because there is no law of nature concerning a precisely 'correct' concentration for a nonharmful, yet therapeutic, effect, the Prometheus patent expressed the discovery as a range of concentrations."). It is not clear what the basis is for Ms. DeFranco concluding "there is no law of nature concerning a precisely 'correct' concentration." How does Ms. DeFranco, or anyone, know? Moreover, whether or not it is a law of nature or physical phenomena, the patentee claimed it is. The claimed correlation might not be exactly correct, but if the patent had been upheld, it would have prevented Mayo from using its test, which test used a slightly different correlation, and which might have been a more correct correlation. Prometheus, $132 \mathrm{~S}$. Ct. at 1296. The Supreme Court has not limited the exclusion of claims of laws of nature to accurate claims. Inaccurate claims could have just as harmful effects on innovation as accurate claims, and limiting the exclusion to accurate claims could make the exclusion impossible to administer. See, e.g., Anita Krishnakumar, Statutory Interpretation in the Roberts Court's First Era: An Empirical and Doctrinal Analysis, 62 HASTINGS L.J. 221, 251 (2010) ("[T] he opinions authored by Justices Scalia, Thomas, Roberts, Kennedy, and Alito exhibited the highest rates of reliance for interpretive tools that promote legal-landscape coherence- that is, other statutes, the dictionary rule, and practical consequences emphasizing administrabilty-based concerns."). Inventors could claim a slightly "inaccurate" correlation and nevertheless argue that a court enjoin the accurate correlation/claim. 
posed the question whether the claims added enough to the relationships to constitute patentable applications. ${ }^{105}$ It explained that there must be "additional features that provide practical assurance that the process is more than a drafting effort designed to monopolize the law of nature itself." 106

The Supreme Court examined each step separately and in the aggregate, and held that the steps were "not sufficient to transform unpatentable natural correlations into patentable applications" of the law of nature. ${ }^{107}$ It concluded that the "administering step" did not add anything to the law of nature, because it referred to doctors who by definition were already treating patients with thiopurine drugs. ${ }^{108}$ The Court also noted that the two "wherein" steps did not add anything to the law of nature because they were "at most . . . a suggestion that he should take those laws into account when treating his patient." 109 The "determining step" did not limit the doctors in any way, because they could "determine the level of the relevant metabolites . . . through whatever process" they chose to use. ${ }^{110}$ Then, considering all the claim elements together, the Court concluded that the three steps in combination added "nothing to the laws of nature that is not already present when the steps are considered separately." "Finally, the Court observed that the steps in the claims beyond the laws of nature were routine steps that the scientific community already understood and employed. ${ }^{112}$ Put another way, there was nothing inventive in the steps.

See the Supreme Court discussion of district court conclusion on that issue in Prometheus, 132 S. Ct. at 1296. See 5B CHISUM, supra note 20, at § 18.04, 18-55260 (including an extended discussion of the doctrine of equivalents).

105 Prometheus, 132 S. Ct. at 1297 (emphasis in original).

${ }^{106} \mathrm{Id}$.

${ }^{107}$ Id. at 1298 .

${ }^{108}$ Id. at 1297. The administering step provided, "(a) administering a drug providing 6-thioguanine to a subject having said immune-mediated gastrointestinal disorder." Id. at 1295.

${ }^{109}$ Id. at 1297. The first "wherein" step was if the level of the 6-thioguanine metabolite was below a certain level (indicating a need to increase the amount of the thiopurine drug), and the second "wherein" step was if the level of 6thioguanine was greater than a different specified level (indicating a need to decrease the amount of the thiopurine drug). Id. at 1295.

${ }^{110} I d$. at 1297 . The determining step provided, "(b) determining the level of 6thioguanine in said subject having said immune-mediated gastrointestinal disorder." Id. at 1295 .

${ }^{111} I d$. at 1298. The additional steps/limitations were "well-understood, routine, conventional activity already engaged in by the scientific community." Id. In other words, the Court ultimately analyzed the steps in the aggregate.

${ }^{112} I d$. 
The Court then noted that consideration of Parker v. Flook, Diamond v. Diehr and Bilski v. Kappos reinforced its conclusion. ${ }^{113}$ In Flook, the Court rejected a method that used a formula to update alarm limits during a catalytic conversion process. ${ }^{114}$ In Prometheus, the Court noted that the claim elements in Flook beyond the formula "were all 'well known,' to the point where, putting the formula to the side, there was no 'inventive concept' in the claimed application of the formula." 115 Explaining the result in Flook, the Prometheus Court also said, "“[P]ostsolution activity' that is purely 'conventional or obvious' . . . 'can[not] transform an unpatentable principle into a patentable process.", "can

In Diehr, the Court held that a patent for a method of molding raw, uncured rubber into a variety of cured molded products that included the use of the Arrhenius equation constituted patentable subject matter. ${ }^{117}$ The Prometheus Court explained that the steps in the Diehr patent "apparently added to the [Arrhenius] formula something that in terms of patent law's objectives had significance." 118 By referring to "no inventive concept" to explain Flook and "added ... something...of...significance" to explain Diehr, the Prometheus Court focused on adding something significant, inventive, to the law of nature to support patentable subject matter. ${ }^{119}$

In Bilski, the Court held that a process for hedging risks relating to price changes constituted an abstract idea and was therefore unpatentable

${ }^{113}$ Id. at $1298-300$. The Court also discussed Benson v. Gottschalk as an example of overly broad claims and an 1841 English patent case, Neilson v. Hartford, upholding a patent for an improved furnace, "since [the patent] explained how the principle [use of hot air worked better than cold air in the furnace] could be implemented in an inventive way." Id. at 1300-01.

${ }_{114}^{114}$ See supra note 61 and accompanying text.

${ }^{115}$ Prometheus, 132 S. Ct. at 1299.

${ }^{116}$ Id. (quoting Flook, 437 U.S. at 590).

${ }^{117}$ See Diamond v. Diehr, 450 U.S. 175, 177-78, 192 n.2; Prometheus, 132 S. Ct. at 1298; supra notes 75-78 and accompanying text.

${ }^{118}$ Prometheus, 132 S. Ct. at 1299.

${ }^{119}$ Many scholars have suggested that the different results in Flook (not patentable subject matter) and Diehr (patentable subject matter) are difficult to reconcile. See, e.g., Bernard Chao, Moderating Mayo, 107 Nw. U. L. REV. COlloquy 82, 89 \& n.38 (2012). As Professor Chao points out, the Court in Prometheus tried to distinguish Flook from Diehr by saying that the "other steps [in Diehr] apparently added to the formula something [without identifying the something] that in terms of patent law's objective had significance." Id. at 88; Diehr, 450 U.S. at 192-93. The apparent tension between the two decisions may be a reflection that although patentable subject matter is a question of law, there can be underlying facts which affect the determination of the legal question. See In re Comiskey, 554 F.3d 967, 975 (Fed. Cir. 2009). 
subject matter. ${ }^{120}$ The Prometheus Court pointed out that Bilski confirmed that simple "field-of-use" limits did not turn an unpatentable idea into patentable subject matter. It explained, "The fact that some of the claims limited hedging to use in commodities and energy markets and specified that 'well-known random analysis techniques [could be used] to help establish some of the inputs into the equation' did not undermine th[e] conclusion" that it was unpatentable subject matter. ${ }^{121}$ In other words, the "inventor" must add something that was not well-known to turn unpatentable subject matter into a patentable application.

In addition, the Prometheus Court cited a number of scholarly works on the risks of overly broad patent claims foreclosing more future innovation than the underlying discovery could justify. ${ }^{122}$ The Court did not adopt the arguments of these eminent scholars as the motivating principles for its holding in Prometheus, but instead agreed that these arguments "reinforces our conclusion that the processes described in the patents are not patent eligible, while eliminating any temptation to depart from case law precedent." 123

\section{Importance of "new" in $\$ 101$ and inventive concept for laws of nature}

In part III of Prometheus, the Court specifically addressed and rejected four of Prometheus's arguments. ${ }^{124}$ First, it rejected the argument that the patent claim met the Bilski transformation test. ${ }^{125}$ Although the Court recognized that the machine or transformation test was a useful and important clue, it emphasized it had never said "the test trumps the "law of nature' exclusion." 126 Second, the Court rejected Prometheus's argument that the Federal Circuit's decision should be affirmed because the particular law of nature reflected in the patent claim was narrow and specific. ${ }^{127}$ It

${ }^{120}$ Bilski v. Kappos, 130 S. Ct. 3218, 3239 (2010). See also notes $79-86$ and accompanying text.

${ }^{121}$ Prometheus, 132 S. Ct. at $1300-01$.

${ }^{122}$ Id. at 1301-02 (citing Life After Bilski, supra note 14; CREATION, supra note 14, at 112; ECONOMIC STRUCTURE, supra note 14, at 305-306.

${ }^{123}$ Prometheus, 132 S. Ct. at 1302.

${ }^{124} \mathrm{Id}$.

${ }^{125} \mathrm{Id}$. For a detailed discussion of the machine-or-transformation test, see CHISUM TREATISE, supra note 20, at $\S 1.03[6][\mathrm{k}]$, pp. 1-329-330.4.

${ }^{126}$ Prometheus, $132 \mathrm{~S}$. Ct. at 1303 (emphasis in original) (referring to the "machine-or-transformation test" discussed in the Supreme Court's decision in Bilski, 130 S. Ct. at 3225-27).

${ }^{127}$ Id. ("[O]ur cases have not distinguished among different laws of nature according to whether or not the principles they embody are sufficiently narrow ... $[T]$ he cases have endorsed a bright-line prohibition against patenting laws of nature, mathematical formulas and the like, which serves as a somewhat more easily administered proxy for the underlying 'building-block' concern.”). 
declined to consider the argument (without examining the accuracy of the facts asserted) that denying patent eligibility would interfere significantly with medical research, particularly in diagnostics. ${ }^{128}$

More significant is the Supreme Court's response to the argument about the word "new" in 35 U.S.C. $\S 101$ and the adoption by Congress of the "novelty" requirement of 35 U.S.C. $\S 102$ in the 1952 Patent Act. ${ }^{129}$ Some courts and scholars had argued that the adoption of the separate statutory novelty requirement essentially repealed by implication the word "new" in $\S 101$, whereas others argued they were two separate requirements. ${ }^{130}$

The Prometheus Court resolved the argument by holding that the two requirements - "new" in $\S 101$ and "novelty" in $\S 102-$ were different

${ }^{128}$ Id. at 1304-35. The Court noted, "[t]he American Medical Association, the American College of Medical Genetics, the American Hospital Association, the American Society of Human Genetics, the Association of American Medical Colleges, the Association for Molecular Pathology, and other medical organizations tell us that if 'claims to exclusive rights over the body's natural responses to illness and medical treatment are permitted to stand, the result will be a vast thicket of exclusive rights over the use of critical scientific data that must remain widely available if physicians are to provide sound medical care.' . . . we must hesitate before departing from established general legal rules lest a new protective rule that seems to suit the needs of one field produce unforeseen results in another ... We need not determine here whether, from a policy perspective, increased protection for discoveries of diagnostic laws of nature is desirable." Id.

129 See Chisum TrEatise, supra note 20, at OV-12-13 ("Whether Congress intended to repudiate the Supreme Court's stringent 'invention' decisions leading up to Great Atlantic \& Pacific Tea[, 340 U.S. 147 (1950),] or merely to codify existing standards was a matter of dispute among the lower courts and commentators."). As enacted by the Patent Act of 1952, § 102 only contained the word "novelty" in the title. That and three clauses in $\S 102$ - clauses (a), (e) and (g) before the effective date of the America Invents Act ("AIA") - have been cited as the novelty requirement. See JANICE M. MUELLER, PATENT LAW (3rd ed. 2009), at 139 [hereinafter MuEller PATENT LAW]. The passage of the "AIA worked significant changes to U.S. patent law, including redefining what counts as prior art. The practical result . . . is that the U.S. patent system will operate under a dual regime ('pre-AIA' and 'post-AIA' rules) for 30 years or more after the AIA's enactment." JANICE M. MUELLER, MUELLER ON PATENT LAW: PATENTABILITY AND VALIDITY (2012) [hereinafter MUELLER TREATISE), Chapter 7 explanatory note at 7-5 through 7-6. None of the complexities about pre-AIA and post-AIA concerning novelty and $\S 102$, however, can change the analysis of the word "new" in $\S 101$, since the AIA did not amend $\S 101$.

${ }^{130}$ Compare Michael Risch, Everything is Patentable, 75 TENN. L. REv. 591, 602 n.74 (2008) [hereinafter Everything is Patentable] with Demaine \& Fellmeth, supra note 82 , at 361,364 ("[T] he requirement that an invention be 'new' requires that the product or process must not have previously existed in nature."). 
but overlapping. As amicus, the United States government had argued that "virtually any step beyond a statement of a law of nature itself should transform an unpatentable law of nature into a potentially patentable application sufficient to satisfy $\S 101$ 's demands" and that the novelty requirement of $\S 102$, the non-obvious requirement of $\S 103$, and the description requirements of $\S 112$ could perform any necessary screening that remain. ${ }^{131}$ The Court rejected that argument as inconsistent with prior law and pointed out that such an "approach . . . would make the 'law of nature' exception to $\S 101$ patentability a dead letter."132 Although acknowledging that the $\S 101$ and $\S 102$ inquiries might at times-but would not always - overlap, the Court cautioned against shifting the patenteligibility inquiry to $\S \S 102$ and 103 and risking "creating significantly greater legal uncertainty, while assuming that those sections can do work that they are not equipped to do."133

In her article cited by the Supreme Court in Prometheus in reference to work that $\S 102$ is not equipped to do, ${ }^{134}$ Professor Rebecca S. Eisenberg identified the work for $\S 101$ :

Each of the categories listed in [§ 102] ... identifies a prior source of human knowledge with no mention of products or phenomena of nature that have not yet come to the attention of humans. ... In other words, without assistance from the doctrine of patentable subject matter, newly discovered products and phenomena of nature do not seem to qualify as prior art under $\S 102$ alone. ${ }^{135}$

Professor Eisenberg concluded that the patentable subject matter requirements of $\S 101$ provide "an additional tool for limiting the scope of patents that might otherwise unduly impede future research." ${ }^{136}$ In particular, Professor Eisenberg noted that "[d]octrinal redundancy is a common feature of legal systems and may make sense if the interest at stake

${ }^{131}$ Prometheus, $132 \mathrm{~S} . \mathrm{Ct}$. at 1303 . The United States had argued that the patent application would "likely fail for lack of novelty under $\S 102$." See id.

${ }^{132} I d$. (citations omitted).

${ }^{133} \mathrm{Id}$. at 1304.

${ }^{134} \mathrm{Id}$.

${ }^{135}$ Rebecca S. Eisenberg, Wisdom Of The Ages Or Dead-Hand Control? Patentable Subject Matter For Diagnostic Methods After In Re Bilski, 3 CASE W. RESERVE J.L. TECH. \& INTERNET 1, 54-55 (2012).

${ }^{136} I d$. at 64. See also Michael D. Davis, The Patenting Of Products Of Nature, 21 RUTGERS COMPUTER \& TECH. L. J. 293, 332-33 (1995) ("The novelty issue is essentially resolved ... by determining whether the invention was known or used prior to its discovery by the patentee ... . [I]n the Supreme Court's view, the 'product of nature' exclusion exists apart from any question of novelty in section 102.”). 
is important." 137

The Court in Prometheus did not detail precise rules for determining what was "new" within the meaning of $\S 101$, but instead set forth a broad standard-"inventive concept"138 - as a guide for distinguishing unpatentable physical phenomena and laws of nature from potentially patentable applications of such phenomena and laws. ${ }^{139}$ This is an important step in clarifying that the building blocks of knowledge and principles behind them remain free from patent law for all to use.

Furthermore, the Court did not slip in "inventive concept" as dicta in Prometheus. Immediately after citing Flook, Morse, and Gottschalk, the Court restated the principle from these cases: "they insist that a process that focuses upon the use of a natural law also contain other elements or a combination of elements, sometimes referred to as an inventive concept,' sufficient to ensure that the patent in practice amounts to significantly more than a patent upon the natural law itself." ${ }^{140}$ Similarly, the Supreme Court in Flook said:

"Even though a phenomenon of nature or mathematical formula may be well known, an inventive application of the principle may be patented. Conversely, the discovery of such a phenomenon cannot support a patent unless there is some other inventive concept in its application." $" 141$

Therefore, the Court in both Prometheus and Flook tied the inventive concept requirement for patentable subject matter to situations in which the patent application focused on a law of nature or natural physical phenomenon.

The Supreme Court even discussed an English patent case, Neilson v. Harford, to provide guidance on the meaning of "inventive concept." Although the patent in Neilson reflected the principle that "hot air promotes

${ }^{137}$ Eisenberg, supra note 135 , at 50.

${ }^{138}$ See Prometheus, 132 S. Ct. at 1294.

${ }^{139}$ See John F. Duffy, Rules and Standards On The Forefront Of Patentability, 51 WM. \& MARY L. REV. 609, 611, 623 (2009) ("Clear rules can provide the certainty that encourages investment both in obtaining and developing the rights, but standards can provide the flexibility to accommodate the hew and unpredictable wonders of human ingenuity ... [T] he law defining limits of patentability has generally been hostile to rule-based approaches, and that hostility has been especially apparent for rules of exclusions at the Supreme Court."). See also Eisenberg, supra note 135, at 14 (discussing the Federal Circuit's preference for bright-line rules and the Supreme Court's decisions typically stating broad openended principles).

${ }^{140}$ Prometheus, 132 S. Ct. at 1294 (citing Flook, 437 U.S. at 594).

${ }^{141}$ Flook, 437 U.S. at 594 (1978) (emphasis added).

${ }^{142}$ See Prometheus, 132 S. Ct. at 1300. 
ignition [in a furnace] better than cold air," it also "included . . . several unconventional steps (such as inserting the receptacle, applying heat to the receptacle externally, and blowing the air into the furnace)." ${ }^{143}$

The Prometheus Court therefore highlighted the Neilson patent as an example that "explained how the principle could be implemented in an inventive way," 144 or in other words, specific steps that had not been used before the principle had been discovered.

\section{E. The Standard-Protecting Basic Building Blocks}

Prometheus is not a recent aberration, but affirms principles recognized by over 150 years of Supreme Court jurisprudence. The Court has applied the principles in the case of product patents ${ }^{145}$ and process patents. ${ }^{146}$ Moreover, much leading scholarship regarding patent law, including biotechnology patents and articles cited by the Supreme Court in Prometheus, supports the Court's application of these principles to DNA segments.

Writing for a unanimous Court in Prometheus, Justice Breyer discussed in detail the importance of the boundaries for patent rights. He repeated twice the Court's statement in Gottschalk that the basic tools of scientific and technological work were not patentable. ${ }^{147} \mathrm{He}$ also referred to the concern about preemption, observing that "upholding the patents would risk disproportionately tying up the use of the underlying natural laws, inhibiting their use in the making of further discoveries." then explained that "the cases have endorsed a bright-line prohibition against patenting laws of nature, mathematical formulas and the like, which serves as a somewhat more easily administered proxy for the underlying 'building-block' concern." "149 Justice Breyer said, "The exclusion from patent law of basic truths reflects ... 'the enormous transaction costs that would

${ }^{143} I d$.

${ }^{144} \mathrm{Id}$.

${ }^{145}$ See, e.g., Am. Fruit Growers, supra notes 48-49 and accompanying text; Funk Bros., supra notes 50-54 and accompanying text; Chakrabarty, supra notes 63-70 and accompanying text.

${ }^{146}$ See Morse, supra note 39 and accompanying text (both product and process); Gottschalk, supra note 59 and accompanying text; Bilski, supra note 79.

147 Prometheus, 132 S. Ct. at 1293, 1301 (emphasis added).

${ }^{148} I d$. at 1294.

${ }^{149} I d$. at 1303. Although the exclusions of laws of nature and physical phenomena are bright-line prohibitions, determining the dividing line between an unpatentable law of nature and a patentable application is in practice a standard. See supra Part I.D.1. 
be imposed on would-be users' of those truths." ${ }^{150}$ Justice Breyer added that patents on such basic truths threatened to inhibit the future development of medical treatment recommendations. ${ }^{151}$

Justice Breyer cited and quoted from a number of scholarly articles to support his concern about patenting basic research. ${ }^{152}$ For instance, Justice Breyer cited Professor Eisenberg's article discussing the Court's Bilski decision. ${ }^{153}$ In that article, Professor Eisenberg concluded that the language in Supreme Court decisions excluding "basic tools of scientific and technological research" hinted at a policy justification to "guide courts today in adapting patentable subject matter doctrine to inventions at the current forefronts of technology." 154 Justice Breyer also cited "Life After Bilski," ${ }^{155}$ in which the authors argued that ideas and natural phenomena were free to all and reserved exclusively to none unless "the patent claims describe the application of human knowledge to a practical end, rather than merely identification of the existence of useful properties." ${ }^{\text {"156 }}$ It is reasonable to conclude that the unanimous Court in Prometheus cited these articles to clarify the boundaries of patent law so courts would apply in the future this broad standard for exclusion from patent protection. These articles are also consistent with a series of other scholarly articles specifically addressing patentable subject matter in the case of biotechnology.

In two seminal 2003 articles challenging the validity of isolated DNA patents, Professors John M. Conley and Roberte Makowski argued for a robust public domain in biotechnology. ${ }^{157}$ They declared, "If the product itself is substantially the same as its natural counterpart, it fails the statutory

${ }^{150}$ Prometheus, 132 S. Ct. at 1302 (quoting ECONOMIC STRUCTURE, supra note 14, at 304-305).

${ }^{151} I d$. at 1302 .

152 See id. at 1294, 1295, 1303 ("[U]pholding the patents would risk disproportionately tying up the use of the underlying natural laws, inhibiting their use in the making of further discoveries. . . . The patent claims at issue here set forth processes embodying researchers' findings that identified these correlations with some precision ... The patent claims seek to embody this research in a set of processes .... [E]ven a narrow law of nature (such as the one before us) can inhibit future research."); ECONOMIC STRUCTURE, supra note 14, at 306.

${ }^{153}$ Prometheus, 132 S. Ct. at 1304 (citing Eisenberg, supra note 135).

${ }^{154}$ Eisenberg, supra note 131, at 8, 64.

${ }^{155}$ Prometheus, 132 S. Ct. at 1302 (citing Life After Bilski, supra note 14). See also Everything is Patentable, supra note 130, for an earlier argument from one of the law journal article's authors, Michael Risch, that everything is patentable subject matter.

${ }^{156} I d$. at 1329.

${ }^{157}$ See Conley \& Makowski, supra note 54, at 306. 
subject matter test, regardless of how it is produced." "Th8 They rejected the idea that claims using "isolated," "purified," or "synthesized" should reflexively receive a patent. Instead, after reviewing "more than a hundred years of precedent," 159 they concluded that "[w]here a claimed invention has a natural counterpart, it must be shown to differ from that counterpart in substance, not merely in degree." 160

In 2004 and 2011, Professor Kane analyzed the patentability of a gene as both a "static chemical compound" and a "dynamic template executed through the genetic code." 161 Professor Kane suggested that "DNA gene sequences ... actually embody a law of nature, as each sequence will govern (and dictate) the execution of a fixed relationship between DNA and protein." 162 She concluded that, gene patenting therefore "results in the constructive preemption of the genetic code." 163 In her 2011 article, she analyzed the basis for the laws of nature, physical phenomena, and abstract ideas exclusion, and observed that " $[t]$ he underlying rationale for the exclusions is that scientific advances depend on an available substrate of basic knowledge and that, therefore, patenting the intellectual foundations of a field has an adverse effect on its progress." 164

In a 2011 article, Allen Yu noted the limits that the Constitution imposed on patent rights covering basic tools of scientific and technological work. ${ }^{165} \mathrm{He}$ argued, "[T]he Court should redefine its vague and relatively weak judicial prohibition against the patenting of nature and abstract ideas in terms of a stronger, more explicit prohibition against the patenting of 'basic tools of scientific and technological work." "166 He continued that any knowledge constituting a basic tool of scientific and technological workthe patenting of which will more likely impede than promote the progress of innovation - should be deemed ineligible for patenting."

\footnotetext{
${ }^{158}$ Conley \& Makowski, supra note 71, at 392.

${ }^{159} \mathrm{Id}$. at 397.

${ }^{160} \mathrm{Id}$.

${ }^{161}$ Eileen M. Kane, Splitting The Gene: DNA Patents And The Genetic Code, 71

TENN. L. REV. 707, 712 (2004); Kane, supra note 26.

162 Béné v. Jeantet, 129 U.S. 683, 686 (1889) (emphasis added).

${ }^{163}$ Kane, supra note 161, at 753. See also id. at 741, 742 (noting, "the strict compositional analysis . . . does not adequately account for the value of a DNA gene sequence claim ... [because] the genetic information survives chemical reformatting from DNA to mRNA to cDNA“).

${ }^{164}$ Kane, supra note 26, at 2.

${ }^{165} \mathrm{Yu}$, supra note 15 , at 428-30.

${ }^{166} \mathrm{Id}$. at 428.

167 Id. at 428-29. See id. at 430 (acknowledging that the question of what constituted a basic tool would not necessarily lead to an easier resolution and arguing, "The main advantage of this requirement is that instead of focusing on
} 
In short, certain "building blocks" of nature are free from patent enclosure; they are free for all to use. ${ }^{168}$ As a standard, however, it remains too vague to guide lower courts. Something more is necessary. Supreme Court cases have implemented the standard through the "proxy" of determining whether the patents at issue improperly claim laws of nature or

legally constructed notions of what is nature and what is man-made, this requirement focuses on articulating the costs of patents."). Many scholars have emphasized limiting the scope of patents as an important tool. See, e.g., Robert P. Merges \& Richard R. Nelson, On The Complex Economics Of Patent Scope, 90 Colum. L. Rev. 839, 913 (1990) ("[I]t is basic to the grant of a patent that the scope of a patent should not exceed the scope of invention ... the purposes of the patent law will be adequately served if patents on compounds which are structurally obvious from the prior art are limited to method (i.e. process) patents directed to the new and useful characteristic or property which is the essence of the discovery or invention.”); DAN L. BURK \& MARK A. LeMLEY, The PATENT CRISIS AND How THE COURTS CAN SOlve IT 104 (2009) ("[A]s a general principle, a flexible common-law approach of ongoing judicial oversight will best accommodate new and different technologies within the general framework of a patent statute."); Robin Feldman, Whose Body Is It Anyway? Human Cells And The Strange Effects Of Property And Intellectual Property Law, 63 Stan. L. ReV. 1377, 1398-400 (2011) ("By allowing a patent on DNA segments in laboratory form, even if those segments are entirely artificial, are we indirectly allowing the patent holder to tie up the natural phenomenon of the gene itself in the human body? ... The solution lies in properly limiting the scope of the allowed claim. In a case like Molecular Pathology, this limitation could be accomplished through the disclosure requirements of 35 U.S.C. § 102.”); Burton T. Ong, Patenting The Biological Bounty Of Nature: e-Examining The Statutes Of Organic Inventions As Patentable Subject Matter, 8 MARQ. INTELL. PROP. L. REV. 1, 8 (2004) (advancing "the proposition that only process patents should be made available in respect to organic inventions because they better reflect what the scientist deserves for his or her inventive efforts and are better measurements of his or her contribution to the preexisting 'biotechnology' of nature").

${ }^{168}$ See Emir Aly Crowne Mohammed, What Is An Invention? A Review Of The Literature On Patentable Subject Matter, 15 Rich. J.L.TeCH. 2, 30 (2008) ("If we accept this line of argument, then any scientific breakthrough that peels back another layer of 'fundamentality' (which is what science does) will reveal that the existing layer was not truly fundamental after all and that awarding patents for that previously fundamental layer is now acceptable, ad infinitum.”). It is true that science has advanced dramatically, but it does not follow that awarding patents for unapplied scientific principles discovered in any particular year is acceptable, because ultimately we will we know much more behind the scientific principle discovered that year, so therefore what we once thought was fundamental is no longer fundamental. In other words, the issue is not whether the natural law is fundamental or not, but whether humans have added enough to the principle to take the claim from a natural law to a specific application of that law with inventive elements beyond the natural law. See supra Part I.D.3. 
physical phenomena without adding an inventive concept. ${ }^{169}$ That proxy is actually implicit in some of the often overlooked words in $\S 101$.

\section{Consistency Between "INVEnt," "New," AND "USEFul" IN § 101 AND THE EXCLUSION OF LAWS OF NATURE AND PHYSICAL PHENOMENA}

\section{A. Introduction}

The words "invent," "new," and "useful," or some iteration of those words, have remained in the U.S. patent statute governing patentable subject matter since $1790 .{ }^{170}$ Scholars and lower courts have tended to focus on the four patent eligible categories in $\S 101$ (processes, machines, compositions of matter and manufactures) and to disregard "new" while treating utility as a separate requirement. ${ }^{171}$ That may be because "invention" and "inventors" are mentioned in a number of other sections of the patent law, ${ }^{172}$ and $\S 102$ addresses the question of novelty, which at least on first glance seems similar to "new."

However, courts must consider the meaning of all the words in a statute, and generally it is improper for a court to ignore certain words when applying a statute. ${ }^{174}$ Although a " word may have a character of its own" ... the words associated with it may indicate that the true meaning of the

${ }^{169}$ Mayo Collaborative Services v. Prometheus Laboratories, Inc., $132 \mathrm{~S}$. Ct. 1289, 1303 (2012).

${ }_{170}^{170}$ See supra note 36 , and accompanying text.

${ }^{171}$ See MoY, supra note 20 , at $\S 5: 1$ ("The authorities refer to the two criteria included in section 101 as the requirements of 'utility' and 'statutory subject matter,' respectively," with "statutory subject matter" referring to processes, machines, articles of manufacture and compositions of matter). For a similar discussion with a focus on four statutory categories, processes, machines, compositions of matter and manufactures, see MUELLER TREATISE, supra note 129, at $\S \S 3.01-3.06$.

172 See 35 U.S.C. $\S 112$ (2012); see also Part I.B, infra.

${ }^{173}$ See MoY, supra note 20, at $\S 5: 1 \mathrm{n} .3$ (arguing that "it has occasionally been asserted that the reference in section 101 to inventions that are 'new' provides the basis for an inquiry into the state of the art ... The large weight of authority, however, holds that the criterion of adequate differences over the art is set out in sections 102 and 103.). But see infra Part I.D.3 (discussing the significance of the Prometheus Court's discussion of "new" in $\S 101$ ).

${ }^{174}$ See, e.g., Duncan v. Walker, 533 U.S. 167, 172-74 (2001) ("We begin, as always, with the language of the statute ... It is our duty give effect, if possible, to every clause and word of a statute."); Krishnakumar, supra note 104, at 236. 
series is to convey a common idea." ${ }^{" 175}$ As a result, courts must consider the "other" words in $\S 101 .{ }^{176}$

\section{B. Invent}

Section 101 requires a patent applicant to have invented what she claims. ${ }^{177}$ As the Supreme Court said in Agawam Woolen Co. v. Jordan, "No one is entitled to a patent for that which he did not invent." Thompson v. Boisselier, the Court said that in order to receive a patent, the claimant "must be an inventor and he must have made a discovery." ${ }^{179}$ In a

${ }^{175}$ Chevron, U.S.A., Inc. v. Natural Resources Defense Council, Inc., 467 U.S. 837, 860, 861 (1984).

${ }^{176}$ See Menell, supra note 37, at 1314 (arguing that patentable subject matter cannot evolve to meet the new challenges of the information age without integrating eighteenth-, nineteenth-, and twentieth-century sources of patentable subject matter law into a flexible and evolving body of common law that is sensitive to history, statutory evolution, constitutional constraints, and an understanding of modern science and technology).

${ }^{177}$ See Mueller TREatise, supra note 129, at $\S 8.01$ ("The patented invention must originate with the inventor. An inventor cannot merely learn from another's invention and thereafter claim it as his own when seeking a patent."). In addition to whether a person actually originated the claimed subject matter, courts have frequently referred to "invention" or "inventive" to refer to a qualitative measure of the difference between prior art and the claimed invention. In that context, courts rejected patents not showing a sufficiently "inventive" leap over prior art. See, e.g., Brown v. Piper, 91 U.S. 37, 41 (1875) ("[T] he application by the patentee of an old process to a new subject, without any exercise of the inventive faculty, and without the development of any idea which can be deemed new or original in the sense of the patent law."). The Patent Act of 1952 enacted 35 U.S.C. § 103, which required that a patent not issue for any claim for which the differences from prior art were obvious, effectively articulating what had been the court-imposed requirement of "inventive" differences. See Dann v. Johnston, 425 U.S. 219, 225-26 (1976) (“As a judicial test, 'invention', i.e., 'an exercise of the inventive faculty,' ... has long been regarded as an absolute prerequisite to patentability ... However, it was only in 1952 that Congress, in the interest of 'uniformity and definiteness,' articulated the requirement in a statute, framing it as a requirement of 'nonobviousness."'). Professor John F. Duffy concluded that $\S 103$ "was designed to end the Court's search for a distinction between ordinary and extraordinary ingenuity and to focus the inquiry solely on obviousness." John F. Duffy, Inventing Invention: A Case Study Of Legal Innovation, 86 TEX. L. ReV. 1, 43 (2007). In Prometheus the Supreme Court relied on the historical court-imposed "inventive" requirement when the subject matter focused on a law of nature to assist in determining whether enough had been added to the law of nature to transform the claim into patentable subject matter under $\S 101$. See infra Part II.D.

17874 U.S. 583, 602 (1868).

${ }^{179}$ See Thompson v. Boisselier 114 U.S. 1, 11 (1885) (involving a patent for improvements in water closets). 
general sense, "discover" can be broader than "invent." ${ }^{180}$ As the D.C. Circuit held in In Re Kemper, "[i]nvention is applied to the contrivance and production of something that did not before exist. Discovery brings to light that which existed before, but which was not known.' A discovery, in this sense, is not the subject of a patent ...."181 Thus, Kemper indicates that the use of "discover" in the context of patentable subject matter referred to a narrower definition of discovery synonymous with invention. ${ }^{182}$

Other federal cases in the Nineteenth Century repeated the principle that in order to obtain a patent, the claimant must go beyond a discovery in the general sense of the word. For instance, Morton v. New York Eye Infirmary involved a patent for the use of ether during surgery on animals. ${ }^{183}$ The court said that a discovery was not patentable and that to be patentable the discovery had to be "connected ... with some particular medium or mechanical contrivance by which ... it acts on the material world." 184

Similarly, in Wall v. Leck, the Ninth Circuit Court of Appeals addressed a process for fumigating trees and plants substantially in the absence of sunlight. ${ }^{185}$ The court noted that the claimant had only discovered that the old process of fumigation was effective if performed at night and had not invented a machine, apparatus device, or process to exclude sunlight. ${ }^{186}$ The court held that such discovery was not a patentable invention and that "[a] mere naked principle, a law of nature, or property of matter cannot be patented." ${ }^{187}$ In short, to be an inventor, a person needs to have passed beyond discovery in the broadest sense.

${ }^{180}$ See Demaine \& Fellmeth, supra note 82, at 370 ("An 'invention,' in the parlance of the Constitution and early patent laws, is a new creation consciously sought and successfully reduced to practice by the inventor. A 'discovery,' as used in the same parlance, was intended to denote a fortuitous creation of the inventor and not merely something found by him or her."). See also Yu, supra note 15, at 431-33; Sarnoff, supra note 15, at 64-66.

${ }^{181}$ In re Kemper, 14 F. Cas. 286, 287 (D.C. Cir., 1841).

${ }^{182} I d$. at 287 (" $[\mathrm{I}] \mathrm{t}$ will be found, by a careful perusal of the constitution and laws of the United States upon the subject of patents for useful arts ... that it is not there used in this [general] sense, but always as synonymous with invention."). 35 U.S.C. $\S 100$ (a) provides, "The term 'invention' means invention or discovery."

${ }^{183}$ See Morton v. N.Y. Eye Infirmary, 17 F. Cas. 879, 881 (C.C.S.D.N.Y. 1862) (involving a patent for the use of ether in surgery on animals).

${ }^{184} \mathrm{See}$ id. at 883 (rejecting the patent claim, as "the specification presents nothing new except the effect produced by well-known agents, administered in well-known ways on well-known subjects. This new or additional effect is not produced by any new instrument ....").

${ }^{185}$ Wall v. Leck, 66 F. 552, 553 (9th Cir. 1895).

${ }^{186} I d$. at 555.

${ }^{187} \mathrm{Id}$. 
Patent disclosure law has reflected the requirement of invention since the first patent statute. ${ }^{188}$ In Evans v. Evans, the Supreme Court said one purpose of the statutory disclosure requirement (the specification) was to enable the public to understand what the applicant "claims as his own invention" and could determine if that invention was already in use. ${ }^{189}$ In Bene v. Jeantet, the Court held that a patent cannot extend the patentee's rights beyond what was her "real invention." 190 In General Electric Co. v. Wabash Appliance Corp., the Court likewise held that an applicant must provide "'a distinct and specific statement of what he claims to be new, and to be his invention." 191

The disclosure statute still reflects the invention requirement in the first paragraph of 35 U.S.C. $\S 112 .{ }^{192}$ That paragraph has three different requirements: (1) enablement, ${ }^{193}$ (2) best mode, ${ }^{194}$ and (3) written

${ }^{188}$ Section 2 of the 1790 Patent Act provided in part that the applicant(s) "shall ... deliver ... a specification in writing, containing a description ... of the things or things, by him or them invented or discovered . . . to enable a workman . . . to make, construct, or use the same . . ." 9 CHISUM TREATISE, supra note 20, at Appendix 9, 9-2. Section 3 of the Patent Act of 1793 provided that every inventor "shall deliver a written description of his invention, and of the manner of using, or process of compounding the same ...." Id. at Appendix 10,10-2. Section 6 of the Patent Act of 1836 provided, "before any inventor shall receive a patent for any such new invention or discovery, he shall deliver a written description of his invention or discovery, and of the manner of and process of making, constructing using, and compounding the same...." Id. at Appendix 11, 11-3. Section 26 of the Patent Act of 1870 provided, "before any inventor or discover shall receive a patent for his invention or discovery, he shall ... file ... a written description of the same, and of the manner of and process of making, constructing using it . . ." Id. at Appendix 14, 14-6.

${ }^{189}$ Evans v. Eaton, 20 U.S. 356, 434 (1822) (emphasis added).

${ }^{190}$ Béné v. Jeantet, 129 U.S. 683, 686 (1889) (emphasis added).

${ }^{191}$ Gen. Elec. Co. v. Wabash Appliance Corp., 304 U.S. 364, 369 (1938).

192 The complete text of paragraph (a) of $\S 112$ (and the first paragraph of $\S 112$ prior to the America Invents Act) is: "The specification shall contain a written description of the invention, and of the manner and process of making and using it, in such full, clear, concise, and exact terms as to enable any person skilled in the art to which it pertains, or with which it is most nearly connected, to make and use the same, and shall set forth the best mode contemplated by the inventor of carrying out the invention." 35 U.S.C. § 112 (2012).

${ }^{193}$ MUELLER TREATISE, supra note 129, at ch. 4; MoY, supra note 20, at $\S \S 7: 2-26$. ${ }^{194}$ Mueller TREATISE, supra note 129, at ch. 5; MoY, supra note 20, at $\S \S 7: 44-$ 57. As a result of the passage of the Leahy-Smith America Invents Act, Pub. L. No. $112-29$ (2011), the failure to comply with the best mode requirement of $\S 112$ is no longer a basis for challenging the validity of a patent or as part of a post-grant review proceeding. See 35 U.S.C. § 282; 35 U.S.C. § 321(b) (2012). 
description. ${ }^{195}$ The purpose of the written description requirement of $\S 112$ (a) is to show that the patent applicant in fact possesses the invention that she claims. ${ }^{196}$ Although historically the Federal Circuit considered the written description requirement in connection with disputes over which applicant for a patent had priority, the Federal Circuit held in Ariad Pharm., Inc. v. Eli Lilly and Co. ${ }^{197}$ that the written description requirement applied to all claims to require possession of the invention. ${ }^{198}$ The Federal Circuit reasoned "a generic claim may define the boundaries of a vast genus of chemical compounds, and yet the question may still remain whether the specification ... demonstrates that the applicant has invented species sufficient to support a claim to a genus." 199

Of course, humans have not invented laws of nature or physical phenomena. ${ }^{200}$ Judge Bryson emphasized this point in his dissent in Myriad

${ }^{195}$ MUELler TREATISE, supra note 129, at ch. 6; MOY, supra note 20, at $\S \S 7: 27$ 43. Professor Landers identifies four disclosure requirements in the first two paragraphs of $\S 112$ : written description, enablement, best mode and definiteness. AMY L. LANDERS, UNDERSTANDING PATENT LAW, § 7.01 (1st. ed. 2008).

${ }^{196}$ See Ariad Pharm, Inc. v. Eli Lilly \& Co., 598 F.3d 1336, 1349 (2010) (agreeing with Lilly's argument that requires that "the specification objectively demonstrate that the applicant actually invented - was in possession of - the claimed subject matter"); Regents of the Univ. of Cal. v. Eli Lilly \& Co., 119 F.3d 1559, 1566 (1997) ("To fulfill the written description requirement, a patent specification must describe an invention and do so in sufficient detail that one skilled in the art can clearly conclude that 'the inventor invented the claimed invention."'); Vas-Cath Inc. v. Mahurkar, 935 F.2d 1555, 1563, 1566 (Fed. Cir. 1991) ("The purpose of the 'written description' requirement is broader than to merely explain how to 'make and use' ... the proper test is whether the drawings conveyed with reasonable clarity to those of ordinary skill that Mahurkar had in fact invented the catheter recited in those claims.").

197 Ariad Pharm., 598 F.3d at 1336 (Fed. Cir. 2010).

${ }^{198}$ Id. at $1349,1351$.

${ }^{199} \mathrm{Id}$. at 1349.

${ }^{200}$ See, e.g., Michael D. Davis, The Patenting Of Products Of Nature, 21 RUTGERS COMPUTER \& TECH. L.J. 293, 314 (1995) ("The basic building blocks necessary for life have remained unchanged throughout evolution."). Whether God or chance resulted in the genetic code is irrelevant for purposes of determining invention, since at least humans did not invent the genetic code. Perhaps Judge Moore, in her concurring opinion in Assoc. for Molecular Pathology v. Myriad Genetics, Inc., 689 F.3d 1303 (Fed. Cir. 2012), was implicitly recognizing that underlying question when she said, "[ $\mathrm{t}]$ he patents in question raise substantial moral and ethical issues related to awarding a property right to isolated portions of human DNA - the very thing that makes us humans, and not chimpanzees." Id. at 1346 (Moore, J., concurring in part). In that connection, it is interesting that the two scientists who won the Nobel Prize for their monoclonal antibody technology determined it would be ethically inappropriate for them to patent their technique. See Rai, supra note 33, at 94 . 
Genetics: "the question in this case is whether an individual can obtain patent rights to a human gene. From a common-sense point of view, most observers would answer, 'Of course not. Patents are for inventions. A human gene is not an invention." 201 In other words, humans have not invented phenomena of nature or laws of nature; they have existed for centuries. Therefore, the $\S 101$ requirement that the applicant shall have invented the claimed subject matter is consistent with the prohibition against patenting of laws of nature and physical phenomena.

\section{New}

The requirement that a patent claim be "new" is also consistent with excluding laws of nature, physical phenomena and the related limitation noted by the Supreme Court in Graham v. John Deere Co. of Kansas City ${ }^{202}$ : "Congress may not authorize the issuance of patents whose effects are ... to restrict free access to materials already available."203 Laws of nature and physical phenomena such as gravity and the genetic code are not new. They have been available for discovery by humans and do not satisfy the $\S 101$ requirement of being new. ${ }^{204}$

The Supreme Court confirmed in Prometheus that there are two separate, but sometimes overlapping, comparisons of patent applications focusing on laws of nature or physical phenomena. The first is a two-part inquiry under $\S 101$ :

a. Do the claims simply reflect a law of nature or physical phenomenon? If so, the claims do not present something that is new, and therefore the subject matter of the claims does not constitute a patentable subject

${ }^{201}$ Myriad Genetics, 689 F.3d at 1348. (Bryson, J., concurring in part and dissenting in part).

${ }^{202}$ Graham v. John Deere Co. of Kansas City, 383 U.S. 1 (1966).

${ }^{203} I d$. at 6 . See also Demaine \& Fellmeth, supra note 82, at 386 (pointing out that products and processes that have existed in nature are not new).

${ }^{204}$ See, e.g., DeFranco, supra note 104, at 27 ("Laws of nature and natural phenomenon are not new."). At least before the decision in Mayo Collaborative Servs. v. Prometheus Labs., Inc., 132 S. Ct. 1289 (2012), there was a dispute about the basis for the three exclusions (laws of nature, physical phenomena and abstract ideas), but recognition that these exclusions were consistent with the text of $\S 101$. In Bilski v. Kappos, the Supreme Court held that "while these exceptions are not required by the statutory text, they are consistent with the notion that a patentable process must be 'new and useful.'” Bilski v. Kappos, 130 S. Ct. 3218, 3225 (2010). Professor Duffy concluded, "In sum, the traditional doctrines of patentable subject matter - the prohibition against patenting abstract ideas, natural phenomena and principles of nature - have survived because they have textual bases in the statute and because they have been amorphous." Duffy, supra note 139, at 646. 
matter within the meaning of $\S 101 ;{ }^{205}$ and

b. If the claims reflect more than a law of nature or physical phenomenon, do the patent claims add enough (an inventive concept) to the natural correlations to allow the processes or products they describe to qualify as patent-eligible processes that apply natural laws? $?^{206}$

The above inquiry on whether or not an applicant has added enough represents a flexible standards-based inquiry consistent with guidance from more than two hundred years of common law. ${ }^{207}$

Therefore, "new" applies to $\S 101$ and "novelty" applies to $\S \S 102$ and 103. Justice Breyer said in Prometheus that "§§ 102 and 103 say nothing about treating laws of nature as if they were part of the prior art when applying those sections."208 Prior art in $\S \S 102$ and 103 only covers knowledge disclosed by humans, so undiscovered laws of nature cannot constitute prior art. ${ }^{209}$ A court thus should not consider laws of nature as prior art for purposes of $\S \S 102$ and 103, because "all inventions can be reduced to underlying principles of nature, which, once known, make their implementation obvious." 110 The placements of "new" with $\S 101$ and "novelty" to $\S \S 102$ and 103 reflect the holding in Diehr that the novelty of an element in a process, or the whole process, "is of no relevance in determining whether the subject matter of a claim falls within the $\S 101$ categories." 211

The decision in Prometheus should end the controversy that had existed over "new" in $\S 101$. $^{212}$ "New" remains a requirement in $\S 101$ and is not "preempted" by the novelty requirement in $\S 103 .{ }^{213}$

205 Prometheus, 132 S. Ct. at 1293, 1296.

${ }^{206} \mathrm{Id}$. at $1294,1298$.

207 See supra notes 132-133 and accompanying text (standards vs. rules); supra notes 37,176 (on the common law nature of $\S 101$ ). Professor Duffy has suggested that "the prohibition against patenting principles of nature still survives . . . because it has been applied more like a standard than a rule." Duffy, supra note 139, at 644 . ${ }^{208}$ Prometheus, 132 S. Ct. at 1304 (2012). Although $\S 103$ does not identify what constitutes "prior art," the reference to $\S 102$ indicates the sources to consider for novelty in $\S 102$ are the same sources to consider for prior art in $\S 103$. CHISUM, supra note 20 , at $\S 5.03[3]$, pp. 5-146 to -7 .

${ }^{209}$ Eisenberg, supra note 135, at 53-55.

${ }^{210}$ Prometheus, 132 S. Ct. at 1304 (quoting Diamond v. Diehr, 450 U.S. 175, 189 90 n.12).

${ }^{211}$ Diehr, 450 U.S. at 189. See also Eisenberg, supra note 135, at 54.

${ }^{212}$ See supra Part I.C.3. 


\section{Useful}

Another consistent requirement of the U.S. patent statutes on patentable subject matter has been that an invention be "useful," an undefined term. ${ }^{214}$ Professor Landes and Judge Posner have identified two economic purposes for the utility requirement. "One is to rule out patents on basic research, and another is to delay the point in the development of a new product or process at which a patent may be obtained." 215

Historically, the courts have set a low standard for what qualifies as "useful." ${ }^{216}$ For instance in a case involving the sale of a beverage dispenser designed to mislead customers, the court concluded the beverage dispenser was useful to the seller. The court reasoned that " $[\mathrm{t}]$ he fact that customers may believe they are receiving fluid directly from the display tank does not deprive the invention of utility[,] . . . even if the use of a reservoir containing fluid that is not dispensed is considered deceptive." 217

Since 1966, however, the courts have applied a more stringent utility requirement in the case of certain chemical and biotech claims. ${ }^{218} \mathrm{In}$

${ }^{213}$ See Liivak, supra note 23, at 264 ("[M] $[\mathrm{M}$ st claims to purified and isolated gene sequences are invalid because such patent claims cannot meet the requirements of the patent act when the patent act is properly interpreted to include a requirement of originality.").

${ }^{214}$ Chisum, supra notes 20; see MUELLER TREATISE, supra note 129, at 6A, p. 235 (" $[\mathrm{T}]$ he statute does not define what useful (or utility) means."); supra note 36. Scholars often reasonably analyze the patentable subject matter separately from the requirement that an invention be useful, while recognizing that "useful" is part of $\S$ 101. See, e.g., Robert P. Merges, Peter S. Menell \& Mark A. Lemley, Intellectual Property in the New Technological Age (6th ed. 2012) (analyzing "Patentable Subject Matter" in Chapter 3B1 and "Utility" in Chapter 3B2); Craig Allen Nard, The LaW OF Patents (2d ed. 2011) (analyzing "Eligible Subject Matter" in Chapter 3A and "Utility" in Chapter 3B).

${ }^{215}$ ECONOMIC STRUCTURE, supra note 14, at 302 . The third purpose they identify is "to reduce the cost of patent searches by screening out useless inventions by cranks or amateurs ...." Id.

216 See Moy, supra note 20, at vol. 2, § 6:1 ("By long-standing judicial interpretation, an invention is generally considered to possess utility if it is minimally useful for its intended purpose ... The statutory requirement therefore forms only a low barrier to patentability in most cases."). See also MUELLER, supra note 129 , at $\S 10.01$.

${ }^{217}$ Juicy Whip, Inc. v. Orange Bang, Inc., 185 F.3d 1364, 1367-68 (Fed. Cir. 1999). See also MUELLER, supra note 129, at 6B, p. 236 ("Utility is rarely an issue for mechanical or electrical inventions; even novelty items, games, or toys that might be considered trivial or frivolous can satisfy the utility requirement.").

${ }^{218}$ See MoY, supra note 20, at vol. 2, § 6:1 ("[T] here may be emerging a more stringent test for adequate utility with regard to chemical products and other inventions that have wide potential uses."); MUELLER TREATISE, supra note 129, at 
Brenner v. Manson, ${ }^{219}$ a case involving a process for making a steroid whose use was not known without further research, the Supreme Court held that the patent failed to meet the requirement of usefulness. ${ }^{220}$ The Court noted that a product, or a process for making a product, was not useful simply because the product was "an object of use-testing,",221 and warned that a "patent is not a hunting license ... [ [or] a reward for the search, but compensation for its successful conclusion.,"222

In a 2005 biotech case, In re Fisher, ${ }^{223}$ the Federal Circuit ruled that a claim for expressed sequence tags lacked utility, because the only use for expressed sequence tags was to identify nucleic acid sequences. ${ }^{224}$ The court ruled that "an application must show that an invention is useful to the public as disclosed in its current form, not that it may prove useful at some future date after further research." 225

Before the decision in Fisher, Professors Eisenberg and Merges argued that "one plausible reading of [Brenner] . . . is that the utility requirement serves a timing function, leaving basic research discoveries in the public domain until they have yielded tangible benefits and have thereby left 'the realm of philosophy' and entered 'the world of commerce.", 226 In addition, Professor Risch observed that the practical use requirement

$\S 10.01$ ("The utility disputes that do arise tend to involve inventions in the chemical and biotechnical arts.").

${ }^{219}$ Brenner v. Manson, 383 U.S. 519 (1966).

${ }^{220} I d$. at 535 .

${ }^{221} \mathrm{Id}$.

${ }^{222} I d$. at 536. In 1999 Professor Rai suggested, "[I]nventions that were primarily useful tools for future researchers ... would not offer the specific commercial utility required by the Supreme Court in [Brenner]." Rai, supra note 33, at 138. Because of the Federal Circuit's decision in Fisher, which is discussed next and which strictly interpreted Brenner, this suggestion about the effect of the utility requirement would still be applicable today.

${ }^{223}$ In re Fisher, 421 F.3d 1365 (Fed. Cir. 2005).

${ }^{224}$ Id. at 1370 . The Federal Circuit explained, "An EST is a short nucleotide sequence that represents a fragment of a cDNA clone. It is typically generated by isolating a cDNA clone and sequencing a small number of nucleotides located at the end of one of the two cDNA strands. When an EST is introduced into a sample containing a mixture of DNA, the EST may hybridize with a portion of DNA. Such binding shows that the gene corresponding to the EST was being expressed at the time of mRNA extraction." Id. at 1367.

${ }^{225}$ Id. at 1371.

${ }^{226}$ Rebecca S. Eisenberg \& Robert P. Merges, Opinion Letter As To The Patentability Of Certain Inventions Associated With The Identification of Partial cDNA Sequences, 23 AIPLA Q.J. 1, 6 (1996). After analyzing in depth the issue of patentability of the EST's in question, they correctly concluded, "Although the matter is not entirely free from doubt, we believe that it is more likely than not that the Federal Circuit would hold all of the claims invalid for lack of utility." Id. at 51. 
"reveals a fundamental normative foundation of the patent system: basic science, no matter how important and valuable, does not merit protection and is therefore not useful in the patent sense." 227

As with the statutory requirements of "invents" and "new," the application of the statutory requirement of "useful" to biotech claims is consistent with the exclusion from patentable subject matter of laws of nature and physical phenomena. ${ }^{228}$ In light of the consistency between the text of $\S 101$, there was no reason for the Federal Circuit not to apply such exclusions to the claims in Myriad Genetics, discussed next. ${ }^{229}$

\section{ApPliCAtion OF the ABOVE PRINCIPLES to the IsOlated DNA AND CDNA CLAIMS IN MYRIAD GENETICS}

\section{A. The Three Often-Conflicting Opinions in Myriad Genetics}

The Federal Circuit's 2012 decision in Myriad Genetics consists of three separate opinions. ${ }^{230}$ Writing as the "majority opinion," 231 Judge

${ }^{227}$ Michael Risch, Reinventing Usefulness, 2010 B.Y.U. L. REV. 1195, 1220 (2010). ${ }^{228}$ In analyzing the Supreme Court's decision in Bilski prior to its decision in Prometheus, Donald S. Chisum argued that "[o]ne way to look at the words 'new and useful' in Section 101, together with the words 'invents' or 'discovers,' is that they limit the four categories to what the Article I patent power calls the "useful Arts,' which in turn has been translated into modern language as 'technology." Donald S. Chisum, Weeds and Seeds In the Supreme Court's Business Method Patents Decision: New Directions for Regulating Patent Scope, 15 LEWIS \& CLARK L. REV. 11, 33, 34 (2011).

${ }^{229}$ This article does not suggest there is a way to turn "building blocks" into an allencompassing theory of patentable subject matter grounded in the Constitution. Among other things, Judge J. Harvie Wilkinson III said (albeit in a different context), "cosmic constitutional theories can falsely suggest simple answers to intractable problems ... The theories supply ingredients of appropriate constitutional interpretation, but only ingredients. To see them as answers is to succumb to the notion that a document as complex as the Constitution can somehow be bottled and pasteurized." JUDGE J. HARVIE WILKINSON III, COSMIC CONSTITUTIONAL Theory: Why AMERICANS ARE Losing Their InALIENABle Right TO SELF-GOVERNANCE 6 (2012). However, using "basic building blocks" seems to be a good starting standard.

${ }^{230}$ The initial Federal Circuit decision in Assoc. for Molecular Pathology v. Myriad Genetics, Inc., 653 F.3d 1329 (Fed. Cir. 2011), also had three opinions by the same judges that were extremely similar to the later decision in Myriad Genetics, 689 F.3d 1303 (2012).

${ }^{231}$ In dissent, Judge Bryson noted, "[a]lthough I recognize that Judge Lourie and Judge Moore, while reaching the same ultimate conclusions, have taken analytical paths that differ in some respects, for convenience I will refer to Judge Lourie's opinion as the majority opinion and Judge Moore's opinion as the concurring opinion." Myriad, 689 F.3d at 1350 n.2 (Bryson, J., concurring in part and 
Lourie concluded that all product/composition claims at issue constituted patentable subject matter, because he believed all the isolated DNA segments were substantially different from the DNA found in humans and were "man-made." 232 Judge Moore was not convinced that the longer strands of isolated DNA in claim $1^{233}$ functioned differently than the native DNA, ${ }^{234}$ but she agreed that the smaller, isolated DNA segments did have markedly different characteristics and functions than those of native DNA. ${ }^{235}$ However, Judge Moore likewise upheld all product/composition claims, largely in deference to the practice of the United States Patent and Trademark Office [USPTO] in granting patents on similar claims for years. ${ }^{236}$

Judge Bryson ended up dissenting "from the court's holding that Myriad's BRCA gene claims and its claims to gene fragments [were] patent-eligible" and argued that the isolated DNA segments of claim 1 were not substantially different in characteristics and utility than those of the DNA found in nature. ${ }^{237}$ Judge Bryson, however, agreed with Judges Lourie

dissenting in part).

${ }^{232}$ Id. at 1308-33 (referring to "man-made" at 1325). This article focuses on what Judge Lourie determined were representative composition claims 1 and 2 of the '282 patent since each of the three opinions discussed whether these claims constituted patentable subject matter. Id. at 309. For identification of each of the claims involved, see Myriad Genetics, 689 F.3d at 1309. Judge Lourie concluded his opinion on the composition claims by stating "the issue before us patent eligibility, not patentability, about which we express no opinion." Id. at 1333 . The method claims decided in Myriad Genetics are beyond the scope of this article.

${ }^{233}$ The representative product claims of the '282 patent are:

1. An isolated DNA coding for a BRCA1 polypeptide, said polypeptide having the amino acid sequence set forth in SEQ ID NO:2 ["Claim 1"].

2. The isolated DNA of claim 1, wherein said DNA has the nucleotide sequence set forth in SEQ ID NO:1. ["Claim 2"].

5. An isolated DNA having at least 15 nucleotides of the DNA of claim 1. ["Claim 5"].

Id. at 1309 .

${ }^{234} I d$. at 1343. Judge Lourie felt the functioning of the DNA segments was irrelevant in determining patentable subject matter. See infra notes 252-260 and accompanying text.

${ }^{235} I d$. at 1342 .

${ }^{236} I d$. at 1343-48. Judge Moore also referred to deference to the expectations of an un-named investment community and to Congress. See infra notes 280-299 and accompanying text.

${ }^{237}$ Id. at 1348, 1354-55 (Bryson, J., concurring in part and dissenting in part) ("[T]he test employed by the Supreme Court in Chakrabarty requires us to focus on two things: (1) the similarity in structure between what is claimed and what is found in nature and (2) the similarity in utility between what is claimed and what is found in nature."). Judge Bryson argued that claims 5 and 6 to short DNA and 
and Moore that the claims for isolated cDNA segments (e.g., claim 2) were patentable subject matter. ${ }^{238}$

\section{Application of Prometheus to Product Patents}

Judge Lourie discounted Prometheus because it involved process claims. Writing for the court, Judge Lourie explained that, "[w]hile [Prometheus] and earlier decisions concerning method claim patentability provide valuable insights and illuminate broad, foundational principles, the Supreme Court's decisions in Chakrabarty and Funk Brothers set out the primary framework for deciding the patent eligibility of compositions of matter, including isolated DNA molecules."

Judge Moore, by contrast, acknowledged that even though Prometheus involved process claims, the application of the laws of nature exception in Prometheus also applied to product claims such as those in Myriad Genetics. ${ }^{240}$ In Judge Moore's opinion, "Myriad's argument that Prometheus is constrained to methods is an untenable position." ${ }^{241}$ Judge Bryson agreed with Judge Moore that Prometheus was not limited to process patents. Citing Prometheus, Judge Bryson reasoned that "a patent involving a product of nature should have an inventive concept that involves more than merely incidental changes to the naturally occurring product." 242

\section{Preemptive effect of claims}

Judge Lourie rejected the concern over preemption the Supreme

cDNA segments were invalid due to overbreadth. $I d$. at 1356 (arguing that "[t]he problem with claim 6 is that it is so broad that it includes products of nature (the BRCA1 exons) and portions of other genes; its validity is not salvaged because it includes some species that are not natural [the cDNA segments]. Accordingly, I would hold claim 6 unpatentable."). With respect to claim 5, he said, "The other claim to a short segment of DNA, claim 5 of the '282 patent, is breathtakingly broad ... Claim 5 would therefore be unpatentable for the same reasons as claim 1 and claim 6." Id. at 1356-57. This article does not address claims 5 or 6 , since all three opinions on whether claims 1 and 2 address more clearly the views of the judges on patentable subject matter, and since the Supreme Court has only granted certiorari on whether human genes are patentable. This article argues that claims 1 and 2 are effectively claims to human genes, whereas claims 5 and 6 are claims to segments of those genes.

${ }^{238}$ See id. at 1329 (Lourie, J., plurality opinion), 1340 (Moore, J., concurring in part), 1355-56 (Bryson, J., concurring in part and dissenting in part).

${ }^{239}$ Id. at 1326-27 (Lourie, J., plurality opinion) (emphasis added).

${ }^{240} \mathrm{Id}$. at 1337-48 (Moore, J., concurring in part).

${ }^{241}$ Id. at 1340 .

${ }^{242} I d$. at 1355 . 
Court expressed in Prometheus, ${ }^{243}$ arguing that, "[a]ny preemption thus is limited, very limited in the case of the present patents. Moreover, patents are rarely enforced against scientific research, even during their terms.",244

The facts and law, however, conflict with Judge Lourie's statement and dismissal of preemption as a concern. First, the earlier part of Judge Lourie's opinion acknowledged that as early as 1998, Myriad's Chief Science Officer had notified a doctor at the University of Pennsylvania's Genetic Diagnostic Laboratory that "Myriad was planning to stop GDL from providing clinical BRCA testing in light of Myriad's patents."245 Judge Lourie's opinion also discussed the cease and desist letters from Myriad and referred to Myriad bringing several patent infringement suits in 1997 and 1998, which they dismissed only "after each defendant agreed to discontinue all allegedly infringing activity." 246 In other words, Judge Lourie's opinion reflected preemption from 1997 through 2015.

In addition, the Supreme Court in Prometheus already rejected Prometheus's suggestion that a claim to a narrow law of nature was permitted, based on concerns with preemption. ${ }^{247}$ Specifically, the Court cautioned that even patents on narrow laws of nature could restrict research and that in "any event, our cases have not distinguished among different laws of nature according to whether or not the principles they embody are sufficiently narrow." ${ }^{248}$ On the contrary, the Court in Prometheus noted that its precedents have "endorsed a bright-line prohibition against patenting laws of nature, mathematical formulas and the like, which serve as a somewhat more easily administered proxy for the underlying 'building block' concern.",249

Judge Bryson was the only judge on the panel in Myriad Genetics who expressed concern about the preemptive effect of claim $1 .{ }^{250} \mathrm{He}$ warned, "some of Myriad's challenged composition claims effectively preempt any attempt to sequence the BRCA genes, including whole-genome sequencing.... [T] hose claims encompass unpatentable subject matter, and

${ }^{243}$ See Mayo Collaborative Servs. v. Prometheus Labs., Inc., 132 S. Ct. 1289, 1301 (2012) ("The Court has repeatedly emphasized . . . a concern that patent law not inhibit further discovery by improperly tying up the future use of laws of nature."). ${ }^{244}$ Myriad Genetics, 689 F.3d at 1331.

${ }^{245}$ Id. at 1314

${ }^{246} \mathrm{Id}$. at 1315 .

${ }^{247}$ Prometheus, 132 S. Ct. at 1294 (holding that "upholding the patents would risk disproportionately tying up the use of the underlying natural laws, inhibiting their use in the making of further discoveries.").

${ }^{248} I d$. at 1303.

${ }^{249} \mathrm{Id}$.

${ }^{250}$ Myriad Genetics, 689 F.3d at 1349 (Bryson, J., concurring in part and dissenting in part). 
a contrary ruling is likely to have substantial adverse effects on research and treatment in this important field." 251

\section{Standard regarding laws of nature}

\section{Chemical Composition Only}

Judge Lourie indicated that the only applicable consideration for determining patentable subject matter was whether the compositions identified in the claims were chemically identical to the native DNA strands in human cells. He admitted that the remand in light of Prometheus might suggest the composition claims were mere reflections of a law of nature."252 However, he rejected that suggestion by focusing on the product and not the genetic code, claiming "Everything and everyone comes from nature, following its laws. But the compositions here are not natural products. They are the products of man, albeit following, as all materials do, laws of nature." 253

Judge Lourie affirmatively rejected any consideration of the functioning of the isolated DNA and native DNA, in contrast to Judges Moore and Bryson. Judge Lourie argued:

Uses of chemical substances may be relevant to the nonobviousness of these substances or to method claims embodying those uses, but the patent eligibility of an isolated DNA is not negated because it has similar informational properties to a different, more complex natural material. ... [T] heir informational content is irrelevant ... . 254

While Judge Lourie clearly prefers relying on the nonobvious requirement in $\S 103$ to examine functioning, ${ }^{255}$ he did not explain how the function of DNA segments could be irrelevant under $\S 101$, in light of the express requirement in $\S 101$ that an invention be "useful." 256

${ }^{251} I d$. In addition to rejecting Claim 1, Judge Bryson argued that the claims to the short segments were overly broad, referring to Claim 5 in particular as "breathtakingly broad." Id. at 1356. Judge Moore recognized the breadth of Claim 5 when she said, "For this claim to be patent eligible, all of the sequences ranging from the 15 nucleotide sequence to the full gene must be patentable subject matter." $I d$. at 1341 (Moore, J., concurring in part). Although Judge Moore recognized that Claim 1 "appears to simply serve the same ends devised by nature," $i d$. at 1343, she did not mention preemption as a factor to consider in determining the validity of either Claim 1 or Claim 5.

${ }^{252} \mathrm{Id}$. at 1331 (Lourie, J., plurality opinion).

${ }^{253} I d$.

${ }^{254} I d$. at 1330

${ }^{255}$ Id. at 1303. See Graham v. John Deere Co, 383 U.S. 1 (1966) (holding that the emphasis on inquiry is on obviousness).

${ }^{256}$ See supra Part II.D. 
Judge Lourie concluded that the chemical characteristics of the isolated DNA segments of claim 1 were markedly different than those of the native DNA. First, he stated that the native DNA, unlike the isolated DNA, "is condensed and intertwined with various proteins, including histones, to form a complex tertiary structure known as chromatin that makes up a larger structural complex, a chromosome." ${ }^{257} \mathrm{He}$ also observed that the "[i]solated DNA has been cleaved (i.e., had covalent bonds in its backbone chemically severed) or synthesized to consist of just a fraction of a naturally occurring DNA molecule." 258

Yet, Judge Lourie did not explain why he rejected consideration of the functioning of the isolated DNA when the Supreme Court considered the functioning of the bacteria in determining patentable subject matter in Chakrabarty and Funk Brothers. In Chakrabarty, the Court held the plasmidenhanced bacteria had "a distinctive name, character [and] use"" than the natural bacteria. ${ }^{259}$ In Funk Brothers, the Supreme Court emphasized that the combination of bacteria did not constitute patentable subject matter, because there was no new bacteria and no additional utility of the existing bacteria." 260

\section{Chemical Composition Plus Function}

Judge Moore considered relevant not only the chemical compositions identified in the isolated DNA claims and the native DNA, but also the functioning of those compositions. Judge Moore said she used "the framework of Funk Brothers and Chakrabarty in conjunction with the direction of Prometheus" 261 and concluded that "a composition of matter with 'markedly different characteristics' from that found in nature with the potential for significant utility is directed to patentable subject matter."262

In referring to the statement in Chakrabarty on "the potential for significant utility,"263 Judge Moore adopted a standard more lenient than that established by the Supreme Court. First, in Chakrabarty the Court repeatedly referred to the functional differences between the plasmid-enhanced bacteria and the bacteria in their natural state. For instance, the Court said that the plasmid-enhanced bacteria were "capable of breaking down multiple

\footnotetext{
${ }^{257}$ Myriad Genetics, 689 F.3d at 1328.

${ }^{258}$ Id.

259 Diamond v. Chakrabarty, 447 U.S. 303, 309-10 (1980) (emphasis added)

(quoting Hartranft v. Wiegmann, 121 U.S. 609, 615 (1887)).

${ }^{260}$ Funk Bros. Seed Co. v. Kalo Inoculant Co., 333 U.S. 127, 131 (1948).

${ }^{261}$ Myriad Genetics, 689 F.3d at 1340.

${ }^{262}$ Id.

${ }^{263}$ Id. (quoting Chakrabarty, 447 U.S. at 310) (emphasis added).
} 
components of crude oil." 264 Second, the Court relied on this difference in actual functioning when it observed, "[b]ecause of this property [i.e., actual functional differences], which is possessed by no naturally occurring bacteria, Chakrabarty's invention is believed to have significant value for the treatment of oil spills." ${ }^{265}$ The actual functioning of the plasmid-enhanced bacteria was central to the Court's reasoning.

Judge Moore came to two different conclusions on the functioning of the claimed compositions. With respect to the shorter isolated DNA segments, she stated the use of "a short strand of DNA as a primer or probe" was a substantially different utility than the natural DNA, which could not be used as a primer or probe ${ }^{266}$ Since the longer isolated DNA segments could not be used as primers or probes, she stated "the chemical and structural differences in the isolated gene do not clearly lead to an 'enlargement of the range of . . . utility' as compared to nature."267 This difference would seem naturally to lead to a conclusion that shorter DNA segments constituted patentable subject matter, but not longer DNA segments.

Indeed, Judge Moore acknowledged that "[i]f [she] were deciding this case on a blank canvas, [she] might conclude that an isolated DNA sequence that includes most or all of a gene is not patentable subject matter." ${ }^{268}$ However, Judge Moore agreed with Judge Lourie that all of the

${ }^{264}$ In addition, the Court said Chakrabarty's claim was “to a nonnaturally occurring manufacture or composition of matter - a product of human ingenuity 'having a distinctive name, character [and] use," "rather than potentially having such a distinctive use. See Chakrabarty, 447 U.S. at 309 (quoting Hartranft v. Wiegmann, 121 U.S. 609,615 (1887)). The Court also referred to the claimed subject as “breaking down multiple components of oil, Chakrabarty's micro-organism," not as potentially breaking down multiple components of oil. Id. at 305 n.2.

${ }^{265} \mathrm{Id}$. at 305.

${ }^{266}$ Myriad Genetics, 689 F.3d at 1342 (Moore, J., concurring in part). Judge Moore did consider the natural functioning of the native DNA, saying, "There is no suggestion that the human body naturally uses 15 -mers as primers to synthesize DNA, or that the attendant process of 'probing' a patient's DNA to detect a mutation is somehow a natural law." Id. Of course, anything found in a human body could presumably be put to a different use that the use of that composition in the body, but if any such outside use could qualify as a sufficient change in use, then anything in the human body would be patentable subject matter outside the body. Accepting such an argument would "make the 'law of nature' exception to $\S 101$ patentability a dead letter," an argument the Supreme Court rejected in Prometheus. Mayo Collaborative Servs. v. Prometheus Labs., Inc., 132 S. Ct. 1289, 1303 (2012).

${ }^{267}$ Myriad Genetics, 689 F.3d at 1343 (Moore, J., concurring in part) (quoting Funk Bros. Seed Co. v. Kalo Inoculant Co., 333 U.S. 127, 131 (1948)).

${ }^{268} I d$. 
product claims of Myriad Genetics constituted patentable subject matter, based on deference to past practices of the USPTO, discussed below. ${ }^{269}$ As a policy matter, this deference to past practices of the USPTO would seem to place the practices of the USPTO ahead of the rulings of the Supreme Court in Chakrabarty and Prometheus.

\section{Chemical Composition Plus Function Plus Inventive Concept}

Judge Bryson rejected in his dissent the argument that the chemical differences between the product reflected in the claim and its native counterpart caused the product to be patentable subject matter. He reasoned that "merely isolating the products of nature by extracting them from their natural location and making those alterations that are attendant to their extraction does not give the extractor the right to patent the products themselves." 270

Judge Bryson recited the test from Chakrabary that both similarities in structure and in utility were important. He concluded that the isolated genes of claim 1 failed this test, noting that " $[t]$ he structural differences between the claimed 'isolated' genes and the corresponding portion of the native genes are irrelevant to the claim limitations, to the functioning of the genes, and to their utility in their isolated form."271

Judge Bryson instead applied the Prometheus inventive concept test to the product claims. Citing Prometheus, he explained "[j]ust as a patent involving a law of nature must have an 'inventive concept' that does 'significantly more than simply describe ... natural relations,' ... a patent involving a product of nature should have an inventive concept that involves

${ }^{269}$ See id. at 1346 ("I decline the opportunity to act where Congress has chosen not to. Congress at least implicitly approved of the Patent Office's policy of awarding patents on genes and DNA sequences. For example, Congress included, as part of the Patent Office's appropriations, language affirming the Patent Office's interpretation of section 101 to prohibit patents on human organisms."). Judge Lourie did not discuss deference to the USPTO, but did say that "disapproving of patents on medical methods and novel biological molecules are policy questions best left to Congress." Id. at 1324-1325 (Lourie, J., plurality opinion).

${ }^{270} I d$. at 1350 . Judge Bryson said that "isolated lithium does not occur naturally because it reacts with air and water and thus is found in nature only as part of a chemical compound, ionically bound to other elements ... Once isolated, lithium has many industrial applications, and in order to isolate lithium, it is necessary to break ionic bonds in the lithium compounds that are found in nature. But it seems plain that elemental lithium (like other elements) would not be patentable subject matter." Id. at 1351. He also argued that removing a kidney from a human being and pulling a leaf off of a tree would make neither the kidney nor the leaf patentable subject matter. $I d$. at 1352.

${ }^{271} I d$. at 1354 (Bryson, J., concurring in part and dissenting in part). 
more than merely incidental changes to the naturally occurring product.."272 When, as in Myriad Genetics, "the applicant claims a composition of matter that is nearly identical to a product of nature," he argued that the following questions were appropriate:

a. "[W]hether the applicant has done 'enough' to distinguish his alleged invention from the similar product of nature";

b. "Has the applicant made an 'inventive' contribution to the product of nature?"; and

c. "Does the claimed composition involve more than 'well-understood, routine, conventional' elements?",273

Judge Bryson concluded that the answer to each of these questions was "no" with respect to the isolated DNA segments of claim $1 .{ }^{274} \mathrm{He}$ emphasized that the natural functioning of the claimed subject matter was crucial under Prometheus:

The informational content of the nucleotide sequences is the critical aspect of these molecules; the terminal groups added to the molecules when the covalent bonds are broken - to which the majority and concurring opinions attribute such significance-are not even mentioned in the claims. The nucleotide sequences of the claimed molecules are the same as the nucleotide sequences found in naturally occurring human genes. ${ }^{275}$

As applied to claim 1, Judge Bryson found "[t]he functional portion of the composition - the nucleotide sequence-remains identical to that of the naturally occurring gene." 276

Judge Bryson also examined the functioning of the DNA segments in claim 1 ("coding for a BRCA1 polypeptide") ${ }^{277}$ when evaluating the significance of chemical changes resulting from the isolation of the genes

${ }^{272} I d$. at 1355 (emphasis added).

${ }^{273} \mathrm{Id}$.

${ }^{274}$ Id. at 1350. Judge Bryson's analysis is consistent with the "inventive concept" principle used by the Prometheus Court, as well as the following statement of Professors Demaine and Fellmeth: "[I]t is a basic precondition of patent protection that applicants must have created the claimed subject matter through an ingenuous mental step . . . In order for a substance based upon a naturally occurring phenomenon to constitute an invention, that substance must be substantially transformed from the state in which it naturally occurs." Demaine \& Fellmeth, supra note 82 , at 461 .

${ }^{275}$ Myriad Genetics, 689 F.3d at 1355 (Bryson, J., concurring in part and dissenting in part).

${ }^{276} \mathrm{Id}$. at 1355.

${ }^{277} I d$. at 1309 (Lourie, J., plurality opinion). 
from the native environment. Judge Bryson explained, "the fact that the cleaved molecules have terminal groups that differ from the naturally occurring nucleotide sequences does nothing to add any inventive character to the claimed molecules." 278 He concluded that the "structural similarity [between isolated DNA and naturally occurring DNA] dwarfs the significance of the structural differences between isolated DNA and naturally occurring DNA, especially where the structural differences are merely ancillary to the breaking of covalent bonds, a process that is itself not inventive." 279

\section{Deference}

One reason Judge Moore cited for upholding claim 1 was, "Congress has, for centuries, authorized an expansive scope of patentable subject matter." ${ }^{280}$ While that is true, the Supreme Court for centuries-in Morse, American Wood Paper, Cochrane, Funk Brothers, Bilski and Prometheus - interpreted the patent statutes to preclude patents claiming natural laws, physical or natural phenomena, or abstract ideas. ${ }^{281}$ As Justice Kennedy emphasized in Bilski, "these exceptions have defined the reach of the statute as a matter of statutory stare decisis going back 150 years."282 Moreover, as set forth above, the text of $\S 101$ is consistent with excluding laws of nature and physical phenomena from patent eligibility, the acts of Congress do not suggest a different outcome than Supreme Court precedents.

The second reason Judge Moore cited for upholding claim 1 was that the "US Patent and Trademark Office had allowed patents on isolated DNA segments for decades." ${ }^{283}$ However, Judge Bryson pointed out that, "prior to the Supreme Court's decision in Chakrabarty, the PTO had determined that microorganisms were not subject to patenting, but the Supreme Court gave no indication [in Chakrabarty] that it regarded that

${ }^{278} I d$. at 1355 (Bryson, J., concurring in part and dissenting in part).

${ }^{279} \mathrm{Id}$.

${ }^{280}$ Id. at 1343 (Moore, J., concurring in part).

${ }^{281}$ See supra Parts I.B \& C.

${ }^{282}$ Bilski v. Kappos, 130 S. Ct. 3218, 3225 (2010).

${ }^{283}$ Myriad Genetics, 689 F.3d at 1343. Interestingly, in a decision at approximately the same time as the first decision of the Federal Circuit in Myriad, the Federal Circuit issued Classen Immunotherapies, Inc. v. Biogen IDEC, 659 F.3d 1057 (Fed. Cir. 2011). In Classen, Judge Moore dissented, $i d$. at 1075, from the two other judges on the panel that found two patents for a "method of immunizing a mammalian subject" were "eligible under $\S 101$ to be considered for patenting." Id. at 1060. The USPTO had approved the patents, but Judge Moore gave no mention of deference to the USPTO and did not even mention the USPTO in her dissent. See id. at $1076-81$. 
view as entitled to deference." 284

Judge Moore also noted that "claims similar to the ones at issue in this case have been the focal point of important litigation," citing Amgen, Inc. v. Chugai Pharmaceutical Co. and Amgen, Inc. v. Hoechst Marion Russel, Inc., but being a focal point does not mean the issue was decided. ${ }^{285}$ In fact, patentable subject matter was not decided in Chugai, ${ }^{286}$ nor was it decided in Hoechst Marion Russel. ${ }^{287}$ Subsequently, Judge Dyk even observed in Intervet Inc. v. Merial Ltd. ${ }^{288}$ that neither the Supreme Court nor the Federal Circuit had "directly decided the issue of the patentability of isolated DNA molecules" and then gave reasons supporting the argument that such molecules did not constitute patentable subject matter. ${ }^{289}$ There was simply no Federal Circuit or Supreme Court holding that decided whether isolated DNA segments constituted patentable subject matter. ${ }^{290}$

${ }^{284}$ Myriad Genetics, 689 F.3d at 1358 (Bryson, J., concurring in part and dissenting in part). Judge Lourie replied to this point, arguing that "there is a clear difference between allowing additional patent protection where none previously existed, and denying patent protection decades (or centuries) after the fact, thereby eliminating a large number of property rights." Id. at 1345 . However, it seems inconsistent for Judge Lourie to argue on the one hand that the Myriad Genetics patents presented no preemption worry because they were about to expire and on the other hand claim that denying patentable subject matter would wreck existing property rights.

${ }^{285}$ Id. at 1344 (Moore, J., concurring in part) (citing Amgen, Inc. v. Chugai Pharm. Co., 927 F.2d 1200 (Fed. Cir. 1991); Amgen, Inc. v. Hoechst Marion Roussel, Inc., 126 F. Supp. 2d 69, 77 (D. Mass. 2011)).

286 Judge Moore is correct that the patent was upheld in Chugai, but patentable subject matter was not argued. See John M. Conley, Gene Patents And the Product of Nature Doctrine, 84 CHI.-KENT L. REV. 109, 116 (2009) ("That Amgen's patent was directed to statutory subject matter was taken for granted and not at issue in the case.").

${ }^{287}$ The issues in Amgen were claim construction, definiteness, inequitable conduct, obviousness, enablement, and written description, not patentable subject matter. 126 F. Supp. 2d at 137-66.

${ }^{288}$ Intervet Inc. v. Merial Ltd., 617 F.3d 1282 (Fed. Cir. 2010).

${ }^{289} \mathrm{Id}$. at 1293 (Dyk, J., concurring in part and dissenting in part).

${ }^{290}$ In what became a companion case to Chakrabarty, In re Bergy, the Federal Circuit held that a claim for a biologically pure culture of the microorganism Streptomyces vellosus was patentable subject matter. 563 F.2d 1031 (C.C.P.A. 1977), vacated, 438 U.S. 902 (1978) for reconsideration in light of Parker v. Flook, 596 F.2d 952 (Fed. Cir. 1979), cert. granted. In re Bergy was dismissed as moot in Diamond v. Chakrabarty, 444 U.S. 1028 (1980). The patent examiner had rejected the patent application on the ground that the claim did not constitute patentable subject matter because the microorganism was a "product of nature." The United States Patent and Trademark Board of Appeals affirmed the rejection of the application, but on the ground that $\S 101$ precluded the grant of patents for living organisms, a slightly different issue. In re Bergy, 563 F.2d at 1033-34. When the 
Judge Moore also argued, "[t]he settled expectations of the biotechnology industry - not to mention the thousands of issued patentscannot be taken lightly and deserve deference." 291 Yet the Supreme Court case Judge Moore cited, Festo Corp. v. Shoketsu Kinzoku Kogyo Kabushiki Co., involved the doctrine of equivalents and the rule of prosecution history estoppel $^{292}$ that had been established through a series of Supreme Court holdings, ${ }^{293}$ not practices by administrative agencies such as the USPTO. Festo is simply an example of Supreme Court deference to the principle of stare decisis. ${ }^{294}$

Judge Moore selectively discussed two lower court cases upholding patents on purified chemical products and concluded "the settled expectations of the inventing community with respect to isolated DNA claims are built upon the broad language of . . . judicial precedent, such as Parke-Davis and Merck." ${ }^{, 295}$ However, earlier in her opinion, Judge Moore admitted that "mere purification of a naturally occurring element is typically insufficient to make it patentable subject matter," citing a number of other

rejection was appealed to the U.S. Court of Custom and Patent Appeals, that court said, "We consider the product-of-nature issue to have been abandoned and no longer in the case."

${ }^{291}$ Myriad Genetics, 689 F.3d at 1344.

${ }^{292}$ Id. (citing Festo Corp. v. Shoketsu Kinzoku Kogyo Kabushiki Co., 535 U.S. 722, 739 (2002)). Judge Lourie referred to both Festo and J.E.M. Ag Supply, Inc. v. Pioneer Hi-Bred Int'l, Inc., 534 U.S. 124, 144-45 (2001), for the practice of the PTO. In J.E.M., however, although the Court did refer to past practices of the PTO, the Court also said that the "Board of Patent Appeals and Interferences, which has specific expertise in issues of patent law, relied heavily on this Court's decision in Chakrabarty when it interpreted the subject matter of $\S 101$ to include plants." 534 U.S. at 145. In contrast, here there has been no federal court decision, let alone a Supreme Court opinion, deciding that isolated DNA segments were patentable. In fact, as described in this article, the more reasonable interpretation of Supreme Court precedents is that such segments are not patentable. Festo, 535 U.S. at 739. Further, in J.E.M., there had been a subsequent express amendment to 35 U.S.C. $\S 119$ (f) supporting the past practices of the USPTO. 534 U.S. at 145. Neither the reference to past Supreme Court decisions in Festo nor the passing reference to USPTO practices in J.E.M. is a basis for deference in Myriad Genetics.

${ }^{293}$ See, e.g., Graver Tank \& Mfg. Co. v. Linde Air Products Co., 339 U.S. 605 (1950); Warner-Jenkinson Co. v. Hilton Davis Chemical Co., 520 U.S. 17 (1997). ${ }^{294}$ Festo, 535 U.S. at 739.

${ }^{295}$ Myriad Genetics, 689 F.3d at 1344 (Moore, J., concurring in part). Judge Moore cited Merck \& Co. v. Olin Mathieson Chemical Corp., 253 F.2d 156 (4th Cir. 1958) (involving products of the fermentation of a vitamin $\mathrm{B}(12)$ activity producing strain of Fungi) and Parke-Davis \& Co. v. H.K. Mulford Co., 189 F. 95 (S.D.N.Y. 1911), aff'd in part, rev'd in part, 196 F. 496 (2d Cir. 1912) (involving a product which had been isolated from the suprarenal glands). 
appellate cases. ${ }^{296}$ Judge Moore also admitted that Funk Brothers "indicates that an invention which 'serve[s] the ends nature originally provided' is likely unpatentable subject matter." ${ }^{297}$ In deferring to the USPTO, Judge Moore disregarded any settled expectations from Funk Brothers and these other appellate cases that isolated products performing the same function as in nature-such as isolated DNA segments-were not patentable." Also, scholars had recognized for years prior to the Supreme Court's decision in Prometheus that isolated DNA segments' patent eligibility remained an unresolved question. ${ }^{298}$ As a result, even if expectations of the investing community were relevant, there was no reason to believe that the investing community believed isolated DNA segments were patentable. ${ }^{299}$

Judge Bryson rejected Judge Moore's views on deference for three basic reasons. First, he pointed out that "the PTO lacks substantive rulemaking authority as to issues such as patentability," and that the Federal Circuit should only defer to the PTO to the extent of "the thoroughness of its consideration and the validity of its reasoning." He concluded that the PTO had not thoroughly considered and studied the issue, so its views were not "worthy of much weight in the analysis of this complex question.",300

Second, Judge Bryson stated that "whatever force the PTO's views on the issue of patent eligibility may have had in the past," that was lessened by the changed position of the United States. ${ }^{301}$ He noted that in

${ }^{296}$ E.g., In re Marden, 47 F.2d 957, 958 (C.C.P.A. 1931) (holding that purified vanadium and uranium are not patentable); Gen. Elec. v. DeForest Radio, Co., 28 F.2d 641, 643 (3d Cir. 1928) (holding that purified tungsten is not patentable).

${ }^{297}$ Myriad Genetics, 689 F.3d at 1338.

${ }^{298}$ See infra note 388 and accompanying text.

${ }^{299}$ See also In re Merz, 97 F.2d 599, 600 (C.C.P.A. 1938), affirming the rejection by the USPTO Board of Appeals of a patent for purifying ultramarine on the basis of General Electric, 28 F.2d at 641, and Marden, 47 F.2d at 958.

${ }^{300}$ Myriad Genetics, 689 F.3d at 1357 (Bryson, J., concurring in part and dissenting in part) (quoting Merck \& Co. v. Kessler, 80 F.3d 1543, 1550 (Fed. Cir. 1996). In Merck, the Federal Circuit explained that "[b]ecause Congress has not vested the Commissioner with any general substantive rulemaking power . . . the rule of controlling deference set forth in Chevron does not apply. Such deference as we owe to the PTO[] . . . thus arises, not from the rule of Chevron, but solely from, inter alia, the thoroughness of its consideration and the validity of its reasoning, i.e., its basic power to persuade if lacking power to control." $80 \mathrm{~F} .3 \mathrm{~d}$ at 1550 . The mention of Chevron refers to Chevron, U.S.A., Inc. v. Natural Res. Def. Council, Inc., 467 U.S. 837 (1984).

${ }^{301}$ Myriad Genetics, 689 F.3d at 1358. The United States filed an amicus brief in support of neither party. Brief for the United States as Amicus Curiae in Support of Neither Party, Assoc. for Molecular Pathology, 689 F.3d 1303 (2012) (No. 20101406), 2010 WL 4853320 [hereinafter US Brief]. The US Brief stated that "the 
Myriad Genetics, "[t]he Department of Justice has twice filed a brief on behalf of the United States in this court taking the position that Myriad's gene claims (other than the cDNA claims) are not patent-eligible." ${ }^{302}$

Third, Judge Bryson also pointed out that prior to Chakrabarty, the PTO had determined that microorganisms were not subject to patenting, but in Chakrabarty the Supreme Court accorded no deference to such PTO decisions. ${ }^{303}$ Judge Bryson added that in Chakrabarty the Court had stated "Congress has performed its constitutional role in defining patentable subject matter in $\S 101$; we perform ours in construing the language Congress has employed."304

\section{Summary}

The differences in the views of Judges Lourie, Moore, and Bryson set forth above on claim 1 are stark. The views of the three judges on cDNA are much closer together. As a result of the divergence in opinions, Part III.B. discusses claim 1 and argues that Funk Brothers, Chakrabarty, and Prometheus require a reversal of the Federal Circuit's holding on claim 1 and support Judge Bryon's dissent. Part III.C. addresses claim 2-the claim pertaining solely to cDNA - and argues that the views of all three judges on claim 2 are incorrect and misapply Prometheus.

\section{B. Claim 1 (DNA \& cDNA)}

\section{DNA, genes, and claim 1}

\section{Claim 1}

"1. An isolated DNA coding for a BRCA1 polypeptide, said polypeptide having the amino acid sequence set forth in SEQ ID NO:2."305

\footnotetext{
United States has concluded that isolated but otherwise unaltered genomic DNA is not patent-eligible subject matter under 35 U.S.C. $§ 101$.” US Brief at* 18 . The US Brief acknowledged that this position was different than past practice of the USPTO, but explained that the District Court's decision had "prompted the United States to reevaluate the relationship between such patents and the settled principle under Supreme Court precedent that the patent laws do not extend to products of nature." Id.

${ }^{302}$ Myriad Genetics, 689 F.3d at 1358.

${ }^{303} \mathrm{Id}$.

${ }^{305}$ Id. (quoting Diamond v. Chakrabarty, 447 U.S. 303, 315 (1980)).

${ }^{305} \mathrm{Id}$. at 1309 .
} 
SEQ ID NO:2 (first line of amino acid sequence in the '282 patent)

Met Asp Leu Ser Ala Leu Arg Val Glu Glu Val Glu Asn Val Ile Asn ${ }^{306}$

Neither humans nor Myriad Genetics created the coding relationship between the claim 1 polypeptides ${ }^{307}$ and the amino acid sequence SEQ ID NO:2. ${ }^{308}$ Judge Lourie seemed to recognize that when he stated " $[\mathrm{t}]$ he relationship between the sixty-four possible codon sequences [groups of three nucleic acids in a DNA strand] and their corresponding amino acids is known as the genetic code."

The relationship between DNA and amino acids is in fact part of the inherent order of life. ${ }^{310}$ DNA dictates the functioning of each individual cell in most forms of life by directing protein production at certain times and amounts. ${ }^{311}$ Genes are the basic units of DNA that are responsible for

${ }^{306}$ This is the list of the amino acids taken from the first line of SEQ ID NO:2. U.S. Patent No. 5,747,282, at col. 81-82 (filed Jun. 7, 1995), available at http://www.google.com/patents/US5747282 [hereinafter U.S. Patent '282].

${ }^{307}$ E.g., id. at fig. $10 \mathrm{~A}$ to $-\mathrm{H}$. See also id. at col. 5 11. $65-7$ to col.6 11. 1-2 (note explaining meaning of Fig. 10A to $-\mathrm{H}$ ).

${ }^{308}$ Id. at col. 81-90.

${ }^{309}$ Myriad Genetics, 689 F.3d at 1312. See also BIOCHEMISTRY, supra note 88, at 816 (similarly defines "genetic code" as "[t]he correspondence between a particular nucleotide codon and the amino acid it specifies. The standard genetic code of 64 codons is used by almost all organisms. The genetic code is used to translate the sequence of nucleotides in mRNA into protein.").

${ }^{310}$ See, e.g., H. Lodish ET AL., MOleCUlar Cell Biology, at app. G-9, 111-2 (6th ed., 2008) [hereinafter MOLECULAR CELL BIOLOGY] (stating that "virtually all the information required for the development of a fertilized egg into an adult made of trillions of cells . . can be stored in the sequence of the four possible nucleotides ... in the human genome .... [V]irtually all forms of life use DNA to encode their genetic information, and also use nearly the same nucleic acid sequence code to specify amino acid sequence ....").

${ }^{311}$ Conley \& Makowski, supra note 54, at 311. For a detailed description of DNA replication and the production of protein by DNA and RNA, see Chapters 20, 21 and 22 of BIOCHEMISTRY, supra note 88 . In addition to genes that encode proteins, "all cells contain genes that are expressed only in special circumstances, such as during cell division. Multicellular organisms also contain genes that are expressed only in certain types of cells." Id. at 647-8. The important biological functions of proteins (also called polypeptides) include: acting as enzymes (biochemical catalysts); binding for storage and transport of other molecules; providing support/shape to cells; decoding information in cells; and doing mechanical work such as contraction of muscles. Id. at 52-53. 
the inheritance of discrete traits in all such living organisms. ${ }^{312}$ Each gene is typically thousands of nucleotides long and generally encodes one or more proteins, meaning the body uses the information in those nucleotides to produce those proteins. ${ }^{313}$ The Federal Circuit explained that " $[\mathrm{m}]$ ost genes have both 'exons' and 'intron' sequences. ... Introns are segments of DNA interspersed between the exons that, unlike exons, do not code for a protein." 314

Every DNA molecule is made up of four nucleotide bases - adenine ("A"), thymine ("T"), cytosine ("C"), and guanine ("G")—which are covalently linked, ${ }^{315}$ or bonded together via a sugarphosphate or phosphodiester backbone. ${ }^{316}$ Claim 1 , however, does not mention either type of backbone. ${ }^{317}$ DNA typically consists of a double helix of two intertwined strands of DNA chemically bound to each other through base pairing. The adenine on one strand of DNA always binds to the thymine on the other strand, and the guanine on one strand always binds to the cytosine on the other strand. ${ }^{318}$

Gene expression is the process by which the information encoded in a gene causes the production of protein. ${ }^{319}$ The synthesis of proteins from

${ }^{312}$ Assoc. for Molecular Pathology v. USPTO, 702 F. Supp. 2d at 194 (S.D.N.Y. 2010), aff'd in part, rev'd in part, 653 F.3d (Fed. Cir. 2011), cert. granted, judgment vacated. See also, Kane, supra note 161, at 708 ("Genes are identified as the discrete units of DNA sequence that encode individual proteins and that collectively underlie the biochemical design of any organism."); Anita Varma \& David Abraham, DNA is Different: Legal Obviousness and the Balance between Biotech Inventors and the Market, 9 HARV. J.L. \& TECH. 53, 57 (1996) ("A gene is a region of DNA on a chromosome whose sequence encodes a specific protein."); BIOCHEMISTRY, supra note 88, at 647 ("We define a gene as a DNA sequence that is transcribed. This definition includes genes that do not encode proteins (not all transcripts are messenger RNA). The definition normally excludes regions of the genome that control transcription but are not themselves transcribed. We will encounter some exceptions to our definition of a gene-surprisingly, there is no definition that is entirely satisfactory.").

${ }^{313}$ Assoc. for Molecular Pathology, 702 F. Supp. 2d at 194.

${ }^{314}$ Myriad Genetics, 689 F.3d at 1311.

${ }^{315} \mathrm{~A}$ covalent bond is a "[s]table chemical force that holds the atoms in molecules together by sharing of one or more pairs of electrons." MOLECULAR CELL BIOLOGY, supra note 310, at app. G-5. See also Myriad Genetics, 689 F.3d at 1310 n. 4.

${ }^{316}$ Myriad Genetics, 689 F.3d at 1310-11. For a more detailed discussion of nucleotides, see BIOCHEMISTRY, supra note 88, at ch. 19.1 .

${ }^{317}$ Myriad Genetics, 689 F.3d at 1309

${ }^{318}$ Id. at 1311; Assoc. for Molecular Pathology v. USPTO, 702 F. Supp. 2d 181, 193-34 (S.D.N.Y. 2010) aff'd in part, rev'd in part, 653 F.3d (Fed. Cir. 2011) cert. granted, judgment vacated.

319 Molecular Cell Biology, supra note 310, at app. G-9. A protein is a macromolecule "consisting of one or more polypeptide chains. The biological 
genes involves two steps: transcription and translation. ${ }^{320}$ During the first stage (transcription), the sequence of a segment of bases in the DNA is copied, or transcribed, into a related molecule called RNA (ribonucleic acid). ${ }^{321}$ RNA is also made up of nucleotides, but a strand of RNA differs from DNA in that it has a different sugarphosphate backbone than DNA, and the DNA base thymine ("T") is replaced by a base called uracil ("U"). ${ }^{322}$ This yields a strand of RNA called pre-RNA, which contains both exons and introns. ${ }^{323}$ The introns are then excised in a process called splicing to produce messenger RNA (or mRNA), which contains only exons. ${ }^{324}$

During the second stage in protein synthesis (translation), the mRNA is translated into the encoded protein "via three nucleotide combinations called codons. ${ }^{, 325}$ Each codon results in the production of one of the twenty amino acids that make up all proteins or a stop signal that terminates protein creation. ${ }^{326}$

\section{No markedly different characteristic and no additional utility}

As discussed above, Judge Lourie concluded that the isolated DNA of claim 1 had markedly different characteristics than those of the native DNA. Judge Lourie based his conclusion on the removal of the DNA from the remainder of the material in the cell-such as the proteins - and the breaking of covalent bonds (shared electrons) between the DNA segments in the process of isolation. ${ }^{327}$ In Chakrabarty, although the Supreme Court considered both additional utility and markedly different characteristics, the Court did not specify any test for determining "markedly different characteristics." As a result, there is no clear standard for arguing that Judge Lourie's view of what constituted markedly different characteristics was incorrect (in contrast to Judge Lourie's complete rejection of any consideration of utility). However, neither Judge Moore nor Judge Bryson agreed with Judge Lourie on the markedly different characteristics analysis,

function of each protein molecule depends not only on the sequence of covalently linked amino acid residues, but also on its three-dimensional structure (conformation)." BIOCHEMISTRY, supra note 88, at 822. "Amino acids are the building blocks of proteins." Id. at 811 .

${ }^{320}$ Myriad Genetics, 689 F.3d at 1311-12.

${ }^{321}$ Id. at 1311.

${ }^{322} \mathrm{Id}$. at 1312 .

${ }^{323}$ Id. at 1312. The District Court referred to this as "pre-messenger RNA" or "premRNA." Myriad Genetics, 702 F. Supp. 2d at 197.

${ }^{324}$ Myriad Genetics, 689 F.3d at 1311. See also BIOCHEMISTRY, supra note 88, at 677-78.

${ }^{325}$ Myriad Genetics, 689 F.3d at 1312.

${ }^{326}$ Id.

${ }^{327}$ Id. at $1328-30$. 
let alone utility.

Judge Moore stated " $[\mathrm{t}] \mathrm{o}$ the extent the majority rests its conclusion on the chemical differences between genomic and isolated DNA (breaking the covalent bonds), [she] cannot agree that this is sufficient to hold that the claims to human genes are directed to patentable subject matter." 328 Of course, Judge Moore was half of that "majority." As set forth above, Judge Moore distinguished between the longer DNA of claim 1 (with no markedly different characteristics) and the shorter DNA of claim 5 (with markedly different characteristics). ${ }^{329}$

In contrast, Judge Bryson stated the court should consider the chemical characteristics of DNA in light of the "informational content" in the genetic code. He argued:

A chemical bond is merely a force between two atoms or groups of atoms strong enough 'to make it convenient for the chemist to consider [the aggregate] as an independent molecular species.' ... [T] o argue that the isolated BRCA gene is patentable because in its native environment it is part of a much larger structure is no more persuasive than arguing that although an atom may not be patentable, a subatomic particle is patentable because it was previously part of a larger structure .... 330

Furthermore, Judge Bryson reasoned that on balance the "structural similarity dwarfs the significance of the structural differences between isolated DNA and naturally occurring DNA, especially where the structural differences are merely ancillary to the breaking of covalent bonds." ${ }^{331}$ The absence of any reference to covalent bonds in claim 1 and claim $2^{332}$ supports Judge Bryson's analysis regarding the insignificance of the structural differences. ${ }^{333}$

The three judges expressed different views on the hypothetical of whether isolated lithium, which is only found in nature as a chemical compound, would be patentable subject matter. ${ }^{334}$ Judge Lourie merely

\footnotetext{
${ }^{328}$ Id. at 1341 .

${ }^{329} \mathrm{Id}$. at $1341-43$.

${ }^{330} \mathrm{Id}$. at $1351,1353$.

${ }^{331} \mathrm{Id}$. at 1355.

${ }^{332} I d$. at 1309.

${ }^{333}$ It is a fundamental principle of patent law that the words of a patent claim define the extent of the invention. Phillips v. AWH Corp., 415 F.3d 1303, 1312 (Fed. Cir. 2005) (en banc); Computer Docking Station Corp. v. Dell, Inc., 519 F.3d 1366, 1373 (Fed. Cir. 2008).

${ }^{334}$ Judge Bryson said that "isolated lithium does not occur naturally because it reacts with air and water and thus is found in nature only as part of a chemical compound, ionically bound to other elements." Myriad, 689 F.3d at 1351
} 
observed lithium was not before the court, "so we do not attempt to evaluate the patentability of one form of lithium over another." ${ }^{335}$ However, all three judges expressed some views on the lithium hypothetical, which evince important clues in considering the impact of the different positions in future cases, particularly if the Supreme Court adopts one of their positions.

Judge Lourie suggested elemental lithium - if it was not found on earth as an element-would be patentable subject matter. Specifically, he reasoned that "if lithium is found in the earth as other than elemental lithium ... . it is a different material." ${ }^{, 336}$ Judge Lourie seems to believe that if a laboratory could separate lithium oxide into lithium and other substances, then elemental lithium would be patentable. Under that theory, there would be no basis for rejecting the patentability of electrons or protons, if a company separated them from their natural surroundings on Earth. Judge Lourie's position disregards the principle that the building blocks of science are not patentable subject matter. ${ }^{337}$

Judge Moore, in contrast, relied on the principle that basic building blocks are not patentable. She suggested that elemental lithium would be patent ineligible because it is "a basic building block provided by nature." 338 Judge Moore attempted to distinguish the patentability of isolated DNA from isolated lithium by speculating that elemental lithium must have existed separately at some time and that "an isolated DNA sequence did not necessarily exist before reacting further to produce the corresponding naturally occurring chromosomal DNA."339 Regardless of which came first - the nucleotide sequences of the genetic code or chromosomal DNAthe genetic code is a basic building block of life reflected in chromosomal DNA and claims 1 and 2 in Myriad Genetics. ${ }^{340}$

Judge Bryson believed the analogy he proposed between chemical elements and isolated DNA was compelling. He argued that "elemental lithium (like other elements) would not be patentable subject matter, even if

(Bryson, J., concurring in part and dissenting in part). Judge Lourie did not disagree with that statement. $I d$. at 1332 (Lourie, J.). Judge Moore responded to the discussion of lithium by "assuming the government's contention that lithium does not currently exist in isolated form in nature" is true. $I d$. at $1345 \mathrm{n} .7$ (Moore, J., concurring in part).

${ }^{335} \mathrm{Id}$. at 1332 . Immediately before that conclusion, Judge Lourie said, "because it reacts with air and water to form, for example, lithium oxide or lithium hydroxide, it is a different material." Id.

${ }^{336} \mathrm{Id}$.

${ }^{337}$ Mayo Collaborative Servs. v. Prometheus Labs., Inc., 132 S. Ct. 1289, 1303

(2012).

${ }^{338}$ Myriad Genetics, 689 F.3d at 1345 n.7.

${ }^{339}$ Id.

${ }^{340}$ See supra notes $161-164$ and accompanying text. 
it could only be extracted from nature through an isolation process." ${ }^{341} \mathrm{He}$ argued that the same principle applied to genetic material such as DNA. ${ }^{342}$

Removing anything found in nature from its natural environment, or synthetically creating it, and putting it in a test tube will of necessity cause some changes in the substance. ${ }^{343}$ If such changes caused that composition to have markedly different characteristics for purposes of $\S 101$ under Judge Lourie's view on "markedly different", then $\S 101$ would be a dead letter, a position the Court expressly rejected in Prometheus. ${ }^{344}$

It is not necessary, however, to rely on the test for "markedly different characteristics" to conclude that the Federal Circuit erred in Myriad Genetics on claim 1, since Judge Lourie rejected any comparison between the utility of the isolated DNA of Claim 1 with that of native DNA. ${ }^{345}$ Instead, he claimed that the uses of a chemical substance could be relevant to a nonobviousness analysis under $\S 103$, but not to a patent eligibility analysis under $\S 101 .{ }^{346}$ Judge Louri's refusal to consider the utility of claim 1 is inconsistent with a number of court precedents and $\S 101$ :

1. Patentable subject matter under $\S 101$ was the sole issue in Chakrabarty, and the Supreme Court relied on the additional utility of the human-engineered bacterium to support its holding of patentable subject matter. $^{347}$ In Funk Brothers the Court rejected a

\footnotetext{
${ }^{341}$ Myriad Genetics, 689 F.3d at 1351.

${ }^{342}$ Id.

${ }^{343}$ Two other examples Judge Bryson gave of "isolations" that could not logically result in transforming unpatentable subject matter into patentable subject matter included (i) removing an apple hanging from an apple tree (which would cause some changes in the bonds which had kept the apple to the tree), and (ii) removing a kidney from a human (which would have caused changes in the unpatentable human organ removed from the human). Id. at 1350-51.

${ }^{344} 132$ S. Ct. at 1303-34.

345 See supra notes 252-260 and accompanying text.

${ }^{346}$ Myriad Genetics, 689 F.3d at 1330.

347 See Diamond v. Chakrabarty, 447 U.S. 303, 303-34 (1980). Not surprisingly, "characteristic" has more than one dictionary definition. Webster's Third New International Dictionary of the English Language Unabridged includes the following two definitions: "a trait, quality, or property or a group of them distinguishing an individual, group or type"; and "any of the variables pertaining to the normal performance of a device (as the grid voltage, plate current, or tube resistance of a vacuum tube or the voltage and watt rating of a lamp)." WEBSTER'S NEW INTERNATIONAL DICTIONARY OF THE ENGLISH LANGUAGE UNABRIDGED (3rd ed. 2002). It is not important to determine whether in Chakrabarty the Court was referring to only static characteristics or performance characteristics, because
} 
patent for the aggregation of bacteria, because the combination had no additional utility. ${ }^{348}$ In both cases the Court the function of the claimed subject matter was crucial to the determination of patentable subject matter.

2. Section 101 refers to the invention or discovery of "any new and useful process, machine, manufacture, or composition of matter." "In Brenner, the Supreme Court applied the utility requirement as a fundamental part of the balancing of interests in granting a patent, stating " $[t]$ he basic quid pro quo contemplated by the Constitution and the Congress for granting a patent monopoly is the benefit derived by the public from an invention with substantial utility." ${ }^{, 350}$ A court must consider the existence of additional utility in determining patentable subject matter under $\S 101$.

3. In Prometheus, the Supreme Court rejected the argument of the U.S. Government that $\S 101$ should take a back seat to $\S \S 102,103$ and 112 in screening out patent claims. ${ }^{351}$ This rejected argument parallels Judge Lourie's view that usefulness can be better considered as part of the nonobviousness requirement of $\S 103$. Citing Funk Brothers, the Court said there claimed subject matter must have a "new and useful end" and an "inventive concept" beyond the law of nature. ${ }^{352}$

Given the statutory language of $\S 101$, the Supreme Court's holding in Chakrabarty and Funk Brothers, and the Court's confirmation in Prometheus of the independent gate-keeping role of $\S 101$, Judge Lourie improperly read "useful" out of $\S 101$ and resisted comparing the utility of the isolated DNA with that of native DNA. Both Judges Moore and Bryson concluded that the isolated DNA of claim 1 did not show utility beyond the utility of the native DNA, ${ }^{353}$ consistent with the district court's findings of

clearly the Court referred to "utility" and considered the functioning of the native bacteria and the human-altered bacteria.

${ }^{348}$ Funk Bros. Seed Co. v. Kalo Inoculant Co., 333 U.S. 127, 131 (1948).

34935 U.S.C. $\$ 101$ (2010).

${ }^{350} 381$ U.S. at 534. See also supra Part II.D.

${ }^{351}$ Mayo Collaborative Servs. v. Prometheus Labs., Inc., 132 S. Ct. 1289, 1303

(2012).

${ }^{352}$ Id. at $1294,1299$.

${ }^{353}$ See supra notes 266-268, 276 and accompanying text. 
fact. ${ }^{354}$ The Federal Circuit, therefore, erred in refusing to consider utility in determining whether claim 1 constituted patentable subject matter.

\section{Nothing inventive added to the product}

The Supreme Court in Prometheus concluded that the patents at issue "set forth laws of nature-namely, relationships between concentrations of certain metabolites in the blood and the likelihood that a dosage of a thiopurine drug will prove ineffective or cause harm. ${ }^{\text {"355 }}$ The Court drew such a conclusion even though the patent claims did not identify any equation and required human action to trigger this relationship. ${ }^{356}$ The Court explained, "[t]he relation is a consequence of the ways in which thiopurine compounds are metabolized by the body-entirely natural processes. And so a patent that simply describes that relation sets forth a natural law."

The fact that the isolated DNA segments of claim 1 had been isolated as the result of human intervention (or synthetically created) ${ }^{358}$ does not change the fact that claim 1 simply reflects the natural relationship between the DNA sequence identified in SEQ ID NO:2 and the identified amino acid sequence in patent $\# 5,747,282 .{ }^{359}$ Indeed, claim 1 of Myriad Genetics in fact expresses that natural law: "DNA coding for a BRCA1 polypeptide." 360

In spite of the Supreme Court's discussion in Prometheus of adding an incentive concept when a patent claim focuses on a law of nature, claim 1 did not contain any inventive concept, and none of the judges in Myriad Genetics disputed that. In fact Judge Bryson pointed out that there was nothing inventive about the "282 patent: "Myriad was not the first to map a BRCA gene to its chromosomal location" and "Myriad did not invent a new method of nucleotide sequencing." "361 Indeed, Judges Lourie and Moore appeared to recognize there was no inventive concept added, since Judge Lourie observed, "Genomic DNA can be extracted from its cellular

${ }^{354}$ Assoc. for Molecular Pathology v. USPTO, 702 F. Supp. 2d 181, 227-32 (2010).

${ }^{355}$ Prometheus, 132 S. Ct. at 1297, 1303.

${ }^{356} \mathrm{Id}$. at 1293.

${ }^{357}$ Id. at 1297.

${ }^{358}$ Assoc. for Molecular Pathology v. USPTO, 689 F.3d 1303, 1329 (2012) (Lourie, J., plurality opinion) (" $[\mathrm{S}]$ ome forms of isolated DNA may require no purification at all, because DNAs can be chemically synthesized directly as isolated molecules.").

${ }^{359}$ See supra notes 252-260 and accompanying text; Figure 10A, supra note 307.

${ }^{360}$ Assoc. for Molecular Pathology, 689 F.3d at 1309 (emphasis added).

${ }^{361}$ Id. at $1348-49$. 
environment using a number of well-established laboratory techniques." 362

Under Prometheus, claim 1 constitutes unpatentable subject matter because Myriad Genetics did not add any inventive concept to the claim. However, even if the inventive concept principle of Prometheus did not apply to the ' 282 patent, claim 1 would still constitute unpatentable subject matter under Chakrabarty and Funk Brothers. The DNA of claim 1 does not have any characteristics markedly different than those of native DNA, nor does the isolated DNA of claim 1 have significantly different utility than that of native DNA. ${ }^{363}$

\section{Applicability of Prometheus to product claims}

Prometheus applies to claims 1 and 2 for a number of reasons. First, a fair reading of Prometheus shows that the Court did not limit the exclusion of laws of nature and natural phenomena to process patents. ${ }^{364}$ Second, in discussing the exclusions, the Court cited favorably a number of product patent cases involving laws of nature or physical phenomena, such as Chakrabarty and Funk Brothers. ${ }^{365}$ Third, limiting the exclusions to process patents would be futile, because drafters would simply include processes within product claims through a number of drafting approaches. Indeed, the Court stated in Prometheus, "cases warn us against interpreting patent statutes in ways that make patent eligibility 'depend simply on the draftsman's art' without reference to the 'principles underlying the prohibition against patents for [natural laws]."” 366

For instance, in Quanta Computer, Inc. v. LG Electronics, Inc. ${ }^{367}$ a case involving the doctrine of patent exhaustion, the Supreme Court observed, "precedents do not differentiate transactions involving embodiments of patented methods or processes from those involving patented apparatuses or materials. ${ }^{368}$ In Quanta, the Court cited an article

${ }^{362}$ Id. at 1313 (Judge Moore's concurrence did not take issue with this observation of Judge Lourie).

${ }^{363}$ Even assuming Judge Moore's conclusion that the shorter isolated DNA segments of claim 1 had a different function than natural DNA, since claim 1 includes both the shorter and longer DNA segments, claim 1 would still be invalid.

${ }^{364}$ Mayo Collaborative Servs. v. Prometheus Labs., Inc., 132 S. Ct. 1289, 1293-94 (2012) (stating that "[ $\mathrm{t}] \mathrm{he}$ Court has long held that this provision contains an important implicit exception ... laws of nature, natural phenomena, and abstract ideas ... are not patentable.")

${ }^{365}$ Id. at $1293-94$.

${ }^{366}$ Id. at 1294 (quoting Parker v. Flook, 437 U.S. 584, 593 (1978)).

${ }^{367}$ Quanta Computer, Inc. v. LG Electronics, Inc., 553 U.S. 617 (2008).

${ }^{368} \mathrm{Id}$. at $628-30$ (in explaining its rejection of the argument that the patent exhaustion doctrine should only apply to product claims, the Court said, "[b]y characterizing their claims as method instead of apparatus claims, or including a method claim for the machine's patented method of performing its task, a patent 
by Professor Thomas stating that "even the most novice claims drafter would encounter scant difficulty in converting a patent claim from artifact to technique and back again.,"369

Moreover, the Federal Circuit and its predecessor have in fact declined to focus on the statutory "category" (i.e., process, manufacture, composition of matter or machine) of individual claims in determining patent eligibility. In CyberSource Corp. v. Retail Decisions, Inc., the Federal Circuit said, "[r] egardless of what statutory category ... a claim's language is crafted to literally invoke, we look to the underlying invention for patent-eligibility purposes." ${ }^{370}$ Similarly, the U.S. Court of Customs and Patent Appeals stated "[1]abels are not determinative in $\S 101$ inquiries" and noted that the form of the claim, whether apparatus or process, is often a drafting decision. ${ }^{371}$

No precedent suggests that excluding laws of nature and physical phenomena from patentability would only apply to the process claims and not to product claims. Indeed, the Supreme Court held in American Fruit Growers and Funk Brothers that the product claims were unpatentable in light of the products in nature. ${ }^{372}$ As Judge Moore stated in her opinion, the "Prometheus discussion of laws of nature (process claims) clearly ought to apply equally to manifestations of nature (composition claims)." ${ }^{\text {373 Judge }}$

drafter could shield practically any patented item from exhaustion.").

369 Id. at 629 n.5. Professor Thomas's article gave the following example: "[C]onsider the following artifact [product] claim: 'An apparatus for measuring activity of the autonomic nervous system of a patient, comprising: means for obtaining ECG signals from said patient whilst said patient is at rest; means for measuring the R-R intervals for adjacent PQRS portions of said signals; means for generating a Poincare plot from said R-R intervals; and means for determining a level of parasympathetic activity for said patient from the width of said plot about a line perpendicular to the line of identity of said plot.' A few simple changes to the claim transforms it to one concerned with technique, in the following way: 'A method of measuring activity of the autonomic nervous system of a patient, comprising the steps of: obtaining ECG signals from said patient whilst said patient is at rest; measuring the R-R intervals for adjacent PQRS portions of said signals; generating a Poincare plot from said R-R intervals; and determining a level of parasympathetic activity for said patient from the width of said plot about a line perpendicular to the line of identity of said plot." John R. Thomas, Text, Technique, and the Tangible: Drafting Patent Claims Around Patent Rules, $17 \mathrm{~J}$. Marshall J. Computer \& InFo. L. 219, 225-26 (1998).

${ }^{370}$ CyberSource Corp. v. Retail Decisions, Inc., 654 F.3d 1366, 1374 (2011).

${ }^{371}$ In re Application of Maucorps, 609 F.2d 481, 485-86 (C.C.P.A. 1979). In any case, Claim 1 does include a process. That process is the coding of amino acids by the claimed DNA segments.

${ }^{372}$ See supra notes 48-54 and accompanying text.

373 Assoc. for Molecular Pathology v. USPTO, 689 F.3d 1303, 1340 (Fed. Cir. 2012). 
Bryson evidently agreed with Judge Moore on this point, since he discussed and applied the Prometheus requirement of an inventive concept. ${ }^{374}$ As Judge Bryson said, "Myriad's argument that Prometheus is constrained to methods is an untenable position." 375

\section{No basis for deferral to the USPTO}

Judge Bryson's refusal to defer to the USPTO should have prevailed for the three basic reasons he set forth ${ }^{376}$ and for a number of additional reasons. First, the Federal Circuit has consistently ruled that patentable subject matter is a question of law for which it gives no deference to the USPTO. For instance, in Fort Properties, Inc. v. American Master Lease $L L C,{ }^{377}$ Fort Properties sought a declaration that an investment method patent was invalid. The District Court granted summary judgment, finding that no claim constituted patentable subject matter and therefore each claim was invalid. ${ }^{378}$ On appeal, the three judge panelincluding Judge Moore - affirmed the District Court and held "[i]ssues of patent-eligible subject matter are questions of law and are reviewed without deference." ${ }^{379}$ Regardless of whether the Federal Circuit referred to no deference to the USPTO or to the District Court, ${ }^{380}$ the Federal Circuit did not in fact defer to the USPTO and held invalid each claim the USPTO had granted. $^{381}$

${ }^{374}$ See 132 S. Ct. 1289, 1294; supra notes 272-276 and accompanying text.

${ }^{375}$ Assoc. for Molecular Pathology, 689 F.3d at 1340.

${ }^{376} \mathrm{Id}$. at 1357-58. See supra notes 300-304 and accompanying text.

${ }^{377}$ Fort Properties, Inc. v. American Master Lease LLC, 671 F.3d 1317 (Fed. Cir. 2012).

${ }^{378} I d$. at 1318 (the patent involved was Patent No. 6,292,788).

${ }^{379} \mathrm{Id}$. at 1320 (emphasis added) (quoting CyberSource Corp. v. Retail Decisions, Inc., 654 F.3d 1366, 1369 (Fed. Cir. 2011)). Judge Bryson was on the judicial panel in CyberSource.

${ }^{380}$ Since the Federal Circuit affirmed the judgment of the District Court, it is logical to conclude the Federal Circuit was referring to no deference to the USPTO.

${ }^{381}$ The reference to question of law really appears to be directed to question of invalidity. The Federal Circuit has indicated in certain situations there can be underlying questions of fact on the question of patentable subject matter. See In re Comiskey, 554 F.3d 967, 975 (Fed. Cir. 2009); Arrhythmia Research Tech., Inc. v. Corazonix Corp., 958 F.2d 1053, 1055-56 (Fed. Cir. 1992). However, to the extent the Federal Circuit thought there were underlying questions of fact, it is difficult to explain the Federal Circuit's decision in light of the conflicting findings of fact by the District Court and any failure of the Federal Circuit to conclude "clear error" in those factual findings granting summary judgment for the plaintiff. $C f$. Stuart M. Benjamin \& Arti K. Rai, Who's Afraid of the APA? What the Patent System Can Learn from Administrative Law, 95 GEO. L.J. 269, 299-300 (2007) (noting that "the Federal Circuit has repeatedly stated that it grants no deference whatsoever to PTO 
Similarly, the majority (including Judges Lourie and Moore) of the Federal Circuit's en banc decision in Bilski gave no deference in tightening requirements for the thousands of business method patents the USPTO had granted. ${ }^{382}$ Then the Supreme Court in Bilski in turn showed no deference to the USPTO or the Federal Circuit in modifying the Federal Circuit's decision.. ${ }^{383}$

Finally, and most recently, the unanimous Supreme Court showed no deference to the USPTO's grant of patents in Prometheus. ${ }^{384}$ In fact, the Court also implicitly rejected the "settled expectations" argument in Prometheus, since Myriad Genetics had filed an amicus brief and argued in part II that the personalized medicine industry was built on the settled expectations of the eligibility of their patents. ${ }^{\text {"385 }}$ Noting that several amici had argued that denying patent coverage would interfere "with the ability of medical researchers to make valuable discoveries," the Court rejected such concerns. ${ }^{386}$ The Court pointed out that the applicable "community" was a vague concept and noted "[o]ther medical experts ... argue strongly against a legal rule that would make the present claims patent eligible, invoking policy considerations that point in the opposite direction." ${ }^{387}$ In sum, there

legal interpretations.” (citing Arnold P'ship v. Dudas, 362 F.3d 1338, 1341 (Fed. Cir. 2004))).

${ }^{382}$ See In re Bilski, 545 F.3d 943, 992-94 (Fed. Cir. 1998) (statistics cited by Judge Newman in dissent).

383 In fact, the only reference to "Trademark Office" in the Supreme Court's decision in Bilski appears to be the following footnote 35 in Justice Stevens's concurring opinion: "Although a few patents issued before 1952 that related to methods of doing business . . . these patents were rare, often issued through selfregistration rather than any formalized patent examination, generally were not upheld by courts, and arguably are distinguishable from pure patents on business methods insofar as they often involved the manufacture of new objects. See In re Bilski, 545 F.3d 943, 974 \& n.18 (Fed. Cir. 2008)." Bilski v. Kappos, 130 S. Ct. 3218, 3246 (2010) (Stevens, J., concurring in the judgment) (internal citations omitted).

${ }^{384}$ Mayo Collaborative Servs. v. Prometheus Labs., Inc., 132 S. Ct. 1289, 1295 (2012).

${ }^{385}$ Brief for Respondent at 12, Mayo Collaborative Servs. v. Prometheus Labs., Inc., 132 S. Ct. 1289 (2012) (No. 10-1150), 2011 WL 5373694, at *12 (capitalization in original).

${ }^{386}$ Prometheus, 132 S. Ct. at 1304-05 (stating that interfering with the ability of medical researchers to make valuable discoveries would be an even more severe restraint than would affecting expectations of the inventing community, but the Court rejected concern over that more severe restraint).

${ }^{387}$ Id. (noting the following distinguished entities arguing against patentability in Prometheus: American Medical Association, the American College of Medical Genetics, the American Hospital Association, the American Society of Human Genetics, the Association of American Medical Colleges, the Association for 
is no legal basis for the Federal Circuit to defer to the USPTO on the issue of patentable subject matter. ${ }^{388}$

\section{Claim 1 conclusion}

Because the subject matter in claim 1 is a BRCA gene, it was error for the Federal Circuit to hold under Prometheus, Chakrabarty, and Funk Brothers that claim 1 was patent eligible. Claim 1 reflects both an inherent physical phenomenon (the gene-comprised of exons and introns) ${ }^{389}$ and a law of nature (the genetic code - the correlation between the nucleotides and the amino acids created by those exons) that humans did not invent. Under Prometheus, there was no step, let alone an inventive step, that claim 1 added to the phenomenon of nature or law of nature that could have resulted in patentable subject matter.

Even if Prometheus did not apply to claim 1, Chakrabarty, Funk Brothers, and over 150 years of Supreme Court precedents required a conclusion of ineligibility. First, the DNA segments of claim 1 did not become markedly different from the native DNA simply because they were "isolated" or synthetically created. ${ }^{390}$ Second, the DNA segments of claim 1

Molecular Pathology. Of course, the Association for Molecular Pathology is the named plaintiff in Myriad Genetics.).

${ }^{388}$ As set forth above in Part III.D.1, scholars have argued since 1990 that whether isolated DNA segments constitute patentable subject matter is an unanswered question. In 1990, Professor Eisenberg noted that "the patents may still be vulnerable to challenges to their validity in the courts." Rebecca S. Eisenberg, Patenting the Human Genome, 39 EMORY L. J. 721, 721-22 \& n.4 (1990). In 2003, Professors Conley and Makowski wrote that "the product of nature doctrine still has a meaningful role to play in the protection of the biological public domain," and that "there is no warrant in the history of the product of nature doctrine for allowing it to be circumvented by the mere incantation of some combination of the words 'isolated,' 'purified,' and 'synthesized." Conley \& Makowski, supra note 71, at 398. In 2004, Professor Kane wrote "[t]he patenting of genes . . results in constructive preemption of the genetic code, an outcome that conflicts with the Supreme Court's dictate that the laws of nature should remain in the public domain, free for all to use." Kane, supra note 161, at 765.

389 See Molecular Cell Biology, supra note 310 (containing the following definition of gene: "Physical and functional unit of heredity, which carries information from one generation to the next. In molecular terms, it is the entire DNA sequences-including exons, introns and transcription-control regionsnecessary for production of a functional polypeptide or RNA."); BIOCHEMISTRY, supra note 88 , at 816 (containing a slightly different definition of gene: "Loosely defined as a segment of DNA that is transcribed. In some cases, the term gene may also be used to refer to a segment of DNA that encodes a functional protein or corresponds to a mature RNA molecule."). This second sentence would include as a gene a cDNA molecule, since those exons are what encodes a functional protein. ${ }^{390}$ Assoc. for Molecular Pathology v. USPTO, 689 F.3d 1303, 1350-53 (2012) 
do not have any utility beyond what native DNA segments have, even if those isolated DNA segments were considered to be markedly different. ${ }^{391}$ Finally, there was no legal basis for the Federal Circuit to defer to the practice of the PTO based on settled expectations of a scientific community.

\section{Claim 2 (cDNA)}

\section{Claim 2 and cDNA}

Complementary DNA, or cDNA, is a type of DNA molecule catalyzed by a protein known as "reverse transcriptase" generated from mRNA (messenger mRNA) 392 during "reverse transcription." 393 During reverse transcription, each mRNA nucleotide serves as a clamp for the complementary nucleotide in the new cDNA molecule as the chemical bonds between the nucleotides of the cDNA strand form. Uracil on the mRNA binds to and acts as a clamp for the adenine on the cDNA, adenine for thymine, guanine for cytosine, and cytosine for guanine. ${ }^{394}$ Since "it is synthesized from mRNA, cDNA contains only the exon sequences, and thus none of the intron sequences, from a native gene sequence." ${ }^{\prime 395}$ As a result of the absence of introns, the production of proteins from cDNA does not require RNA splicing, in contrast to the production of the same protein from native DNA. ${ }^{396}$

("But to argue that the isolated BRCA gene is patentable because in its native environment it is part of a much larger structure is no more persuasive than arguing that although an atom may not be patentable, a subatomic particle is patentable because it was previously part of a larger structure, or that while a tree is not patentable, a limb of the tree becomes a patentable invention when it is removed from the tree.").

${ }^{390}$ Id. at 1342-44 (Moore, J., concurring).

${ }^{391} I d$.

${ }^{392}$ See supra note 324 and accompanying text.

${ }^{393}$ Assoc. for Molecular Pathology v. USPTO, 702 F. Supp. 2d 181, 198 (2010). See also HORTON ET AL., supra note 88, at 729, 815, 823 (referring to reverse transcriptase as an enzyme but also stating that an "enzyme" is a "biological catalyst, almost always a protein").

${ }^{394}$ Assoc. for Molecular Pathology, 702 F. Supp. 2d at 198.

395 Assoc. for Molecular Pathology, 689 F.3d at 1313.

${ }^{396}$ See Assoc. for Molecular Pathology, 702 F.Supp.2d at 198-99 (stating that a scientist typically generates cDNA in a laboratory). However, cDNA does exist in nature as a result of retroviruses (viruses that have two identical RNA strands). Molecular Cell Biology, supra note 310 , at 158. In the life cycle of a retrovirus, "a viral enzyme called reverse transcriptase initially copies the viral RNA genome into single-stranded DNA complementary to the virion RNA; the same enzyme then catalyzes synthesis of a complementary DNA strand." Id. A "virion" is "an individual viral particle." Id. at app. G-24. For additional discussion of retroviruses, see id. at 159 and 229-30. 
By definition, the cDNA of claim 2 is a subset of the DNA of claim 1 , since claim 2 is a dependent claim. ${ }^{397}$ Reading the two claims together, claim 2 is: "The isolated DNA of claim 1 [DNA coding for a BRCA1 polypeptide with the amino acid sequence set forth in SEQ ID NO:2], wherein said DNA has the nucleotide sequence set forth in SEQ ID NO:1." SEQ ID NO: 1 lists the sequence of the nucleotides ${ }^{398}$ in the first row below, all coding for the amino acids identified in the second row below: ${ }^{399}$

SEQ ID NO:1 (mentioned in claim 2)

ATG GAT TTA TCT GCT CTT CGC GTT GAA GAA GTA CAA AAT GTC ATT AAT ${ }^{400}$ Met Asp Leu Ser Ala Leu Arg Val Glu Glu Val Glu Asn Val Ile Asn ${ }^{401}$

This amino acid sequence is the same sequence listed below in SEQ ID NO2 from claim 1:

Met Asp Leu Ser Ala Leu Arg Val Glu Glu Val Glu Asn Val Ile Asn ${ }^{402}$

Put another way, claim 2 does not add any material, but merely narrowed claim 1 . The only difference between claim 1 and claim 2 is that introns (non-coding nucleotides) are absent from the DNA in claim $2 .{ }^{403}$

39735 U.S.C. $§ 112$ (2010), 94 (pre-AIA) provides that, "[s]ubject to the following paragraph, a claim in dependent form shall contain a reference to a claim previously set forth and then specify a further limitation of the subject matter claimed. A claim in dependent form shall be construed to incorporate by reference all the limitations of the claim to which it refers." (Post-AIA, the same paragraph is lettered (d) and begins, "Subject to subsection (e).").

${ }^{398}$ The nucleotides are grouped in threes and called codons.

${ }^{399}$ Each amino acid is identified by three letters, in contrast to each base, which is identified by one letter, A, T, G or C. See Assoc. for Molecular Pathology, 689 F.3d at 1310-11; infra notes 425-426 and accompanying text.

${ }^{400}$ This is one line from SEQ ID NO:1 - the list of nucleotides in U.S. Patent '282, supra note 306, at col. 69-70.

${ }^{401}$ This is a list of the amino acids coded by the nucleotide sequence immediately above the amino acid. Id. at col. 69-70. The amino acids on this line are Methionine, Asparagine, Leucine, Serine, Alanine, Leucine, Arginine, Valine, Glutamine, Glutamine, Valine, Asparagine, Valine, Isoleucine and Asparagine. See The Chemistry of Amino Acids, DeP'T OF BIOCHEMISTRY \& MOLECUlaR BIOPHYSICS AT UNIV. OF ARIZ., http://www.biology.arizona.edu/ biochemistry/problem_sets/aa/aa.html (last visited Apr. 13, 2013).

${ }^{402}$ This is the list of the amino acids taken from the first line of SEQ ID NO:2 from U.S. Patent '282, supra note 306, at col. 81-82.

${ }^{403}$ See Assoc. for Molecular Pathology, 689 F.3d at 1329 ("Claim 2 of the '282 patent is narrower than claim 1 and reads only on cDNAs, which lack the noncoding introns present in the genomic BRCA1 gene.") (Lourie, J., plurality opinion). 


\section{Federal Circuit's focus on the product vs. the law of nature}

Judge Lourie focused on cDNA as a product, disregarding the law of nature reflected in the genetic code set forth in claim 2 . He seemed to rely on the government's argument that cDNA molecules "were engineered by man ... [and] with rare exceptions, they do not occur in nature, either in isolation or as contiguous sequences within a chromosome."404 Judge Lourie concluded that since the cDNA lacked the non-coding introns existing in natural DNA before transcription, ${ }^{405}$ cDNA was patentable because " $[t]$ hey are even more the result of human intervention into nature [than the DNA molecules of claim 1 that were not cDNA] and are hence patent-eligible subject matter." 406

Judge Moore also focused on the cDNA as a product rather than on the law of nature involved and emphasized that "the claimed cDNA sequences do not exist in nature." ${ }^{, 407}$ Yet in Prometheus, even though the

\footnotetext{
${ }^{404} I d$. at 1326. It seems reasonable to conclude from Judge Lourie's statement about "rare exceptions" that he recognizes that in some situations cDNA was found in nature.

${ }^{405}$ See supra notes 392-396 and accompanying text.

${ }^{406}$ Assoc. for Molecular Pathology, 689 F.3d at 1329. The District Court in Myriad Genetics granted summary judgment in part, after stating the rule that "[s]ummary judgment is granted only where there exists no genuine issue of material fact and the moving party is entitled to judgment as a matter of law." Assoc. for Molecular Pathology v. USPTO, 702 F. Supp. 2d 181 (2010) (citations omitted). In contrast, the Federal Circuit eschewed any discussion of the standard for summary judgment. See generally Assoc. for Molecular Pathology, 689 F.3d at 1324-25. Even though determining the existence of patentable subject matter is ultimately a question of law, there can be underlying factual disputes involved in determining patentable subject matter. See Arrythmia Research Tech., Inc. v. Corazonix Corp., 958 F.2d $1053,1055-56$ (Fed. Cir. 1992) ("Whether a claim is directed to statutory subject matter is a question of law ... determination of this question may require findings of underlying facts specific to the particular subject matter and its mode of claiming . ....”. See also In re Comiskey, 499 F.3d 1365, 1373 (Fed. Cir. 2007) ("[T]here may be cases in which the legal question as to patentable subject matter may turn on subsidiary factual issues"). It is beyond the scope of this article to discuss whether summary judgment for either party was appropriate in light of the differences between the findings of fact of the District Court and the Federal Circuit's apparently fact-based view of cDNA. Regardless of whether granting summary judgment was error as a matter of law in light of the apparent disagreement on facts, to decide such crucial issues relating to the building blocks of life when there are genuine disputes about the facts seems unfortunate.

${ }^{407}$ Assoc. for Molecular Pathology, 698 F.3d at 1340 (Moore, J., concurring in judgment). This paragraph accepts for the sake of argument Judge Moore's claim that cDNA does not exist in nature, in spite of the contrary finding of the District Court.
} 
record indicated that thiopurine drugs did not exist in nature, ${ }^{408}$ the Supreme Court held that the patents "set forth laws of nature - namely, relationships between concentrations of certain metabolites in the blood and the likelihood that a dosage of a thiopurine drug will prove ineffective or cause harm." ${ }^{409}$ In other words, the relationship between chemicals inserted into the human body and the reaction of the human body reflected an unpatentable natural law, even though the claim included no mathematical formula and the chemicals inserted were not found in nature.

Judge Bryson similarly focused on a product instead of the law of nature involved, stating " $[\mathrm{t}]$ he cDNA cannot be isolated from nature, but instead must be created in the laboratory." 410 He further stated " $[\mathrm{t}]$ he end product is a human-made invention with distinct structure."411

Contrary to the Federal Circuit panel's focus on whether cDNA existed in nature in the same form, Supreme Court precedents have established that human intervention does not automatically transform a physical phenomenon or law of nature into patentable subject matter. In Badische, the Supreme Court invalidated a patent for artificial alizarine produced by humans from anthracine. ${ }^{412}$ The Court held that, although the process for making the synthetic alizarine could be patentable, the product was not and noted that "[c] alling it artificial alizarine did not make it a new composition of matter." 413

There was again human intervention in American Fruit Growersthe addition of borax to the rind of citrus fruit to render the fruit resistant to

${ }^{408}$ The lower court record indicates thiopurine drugs are man-made. In Prometheus Labs., Inc. v. Mayo Collaborative Servs., 2008 WL 878910, *6 (S.D. Cal. 2008), the District Court rejected Prometheus Labs' argument "that the claimed correlations cannot be natural phenomena because the correlations would not have existed without the intervention of man-made drugs." In Prometheus Labs., Inc. v. Mayo Collaborative Servs., 581 F.3d 1336, 1343 (Fed. Cir. 2009), the Federal Circuit rejected the argument that "Bilski does not apply where, as here, the treatment methods use synthetic drugs and thus do not recite or wholly preempt any natural phenomenon."

${ }^{409}$ Mayo Collaborative Servs. v. Prometheus Labs., Inc., 132 S. Ct. 1289, 1296 (2012).

${ }^{410}$ Assoc. for Molecular Pathology, 689 F.3d at 1356 (Bryson, J., concurring in part and dissenting in part).

${ }^{411} I d$.

${ }^{412}$ See supra note 41 and accompanying text.

${ }^{413}$ Cochrane v. Badische, 111 U.S. 293, 311 (1884). While John Conley and Roberte Makowski have referred to this view of the case as "effectively dictim," they are mistaken. Conley \& Makowski, supra note 54, at $328 \mathrm{n} .193$ (2003). This is not dictum, because the Court did not choose between the two views of the case when it concluded that "[i]n either view the decree of the circuit court must be reversed ...." Cochrane, 111 U.S. at 313. 
blue mold decay. ${ }^{414}$ Yet the Supreme Court invalidated the patent, even though the human-treated fruit had borax in the rind, which natural fruit did not have, and the added borax allowed the human-treated fruit to stay fresh longer than the natural fruit. ${ }^{415}$

Similarly in Funk Brothers the mixing together of certain bacteria into a powder of liquid base by humans did not make the patent valid. ${ }^{416}$ Although mixing bacteria avoided inhibiting effects that certain bacteria naturally had on other bacteria, the Supreme Court concluded, "[t]he combination of species produces . . . no enlargement of the range of their utility." ${ }^{417}$ Such utility reflected "manifestations of laws of nature, free to all men and reserved exclusively to none." 418

There was sufficient human intervention in Chakrabarty for the Supreme Court to find patentable subject matter, but that decision cannot support the Federal Circuit's decision in Myriad Genetics. In Chakrabarty, the Supreme Court noted Congress "recognized that the relevant distinction was not between living and inanimate things, but between products of nature, whether living or not, and human-made inventions." ${ }^{419}$ In referring to "human-made inventions," the Court did not suggest that any human intervention would be sufficient. Instead, the Court held that the plasmidinjected bacteria constituted patentable subject matter because it was "a product of human ingenuity, 'having a distinctive name, character [and] use." "420 Indeed, the reference in Chakrabarty to human ingenuity mirrors the Court's reference to "inventive concept" in Prometheus when the claim focuses on a law of nature. ${ }^{421}$

Most recently, Prometheus also featured human intervention in administering a drug to an individual and determining the level of related metabolites in the individual. ${ }^{422}$ The Supreme Court held that these steps of administering by doctors and determining by doctors were "not sufficient to transform unpatentable natural correlations into patentable applications." The Court emphasized that its precedents insisted that a process that focuses upon the use of a natural law contain additional elements, an inventive

\footnotetext{
${ }^{414}$ Am. Fruit Growers, Inc. v. Brogdex Co., 283 U.S. 1, 6 (1931).

${ }^{415}$ See supra notes 48-49 and accompanying text.

${ }^{416}$ See supra notes 50-54 and accompanying text.

${ }^{417}$ Funk Bros. Seed Co. v. Kalo Inoculant Co., 333 U.S. 127, 131 (1948).

${ }^{418} I d$. at 130.

${ }^{419}$ Diamond v. Chakrabarty, 447 U.S. 303, 313 (1980).

${ }^{420} \mathrm{Id}$. at 310 (emphasis added) (quoting Hartranft v. Wiegmann, 121 U.S. 609, 615 (1887)).

${ }^{421}$ Mayo Collaborative Servs. v. Prometheus Labs., Inc., 132 S. Ct. 1289, 1294, 1299 (2012).

${ }^{422}$ Id. at 1295.

${ }^{423} I d$. at 1298 .
} 
concept, but the additional steps in Prometheus consisted of "wellunderstood, routine, conventional activity already engaged in by the scientific community." 424

Human intervention does not necessarily render the resultant substance or process a patentable subject matter instead of an excluded law of nature or physical phenomenon. Judges Lourie, Moore, and Bryson appeared to disregard this principle in evaluating claim 2 , even though Judge Lourie admitted "[t]he relationship between the sixty-four possible codon sequences and their corresponding amino acids is known as the genetic code." ${ }^{, 425}$ None of the three judges suggested that humans created this genetic code, and indeed the District Court in Myriad Genetics held "it is undisputed that the ordering of the nucleotides is determined by nature." ${ }^{426}$

\section{Judge Moore's analysis of characteristics and function of cDNA}

Judge Moore discussed the difference between isolated cDNA and native RNA and between isolated cDNA and native DNA. She said that cDNA has a complementary sequence of nucleotides, and, as a result, a different nucleotide sequence than RNA. She added that DNA has a different chemical structure than RNA, including a different base (thymine instead of uracil) and different sugar backbones (deoxyribose instead of ribose) ${ }^{427}$ Different chemical structures result in greater stability for the DNA than for the RNA sequence. ${ }^{428}$ Therefore, Judge Moore concluded, "cDNA sequences thus have a distinctive character and use, with markedly different chemical characteristics from either the naturally occurring RNA or any continuous DNA sequence found on the chromosome." 429

The more apt comparison, however, is between the cDNA of claim 2 and the corresponding natural DNA segment. With respect to the comparison, Judge Moore said, "since cDNA has all of the introns removed, and only contains the coding nucleotides, it can be used to express a protein

\footnotetext{
${ }^{424} I d$. at 1294 .

${ }^{425}$ Assoc. for Molecular Pathology v. USPTO, 689 F.3d 1303, 1312 (Fed. Cir. 2012); see also supra notes 309-310. This is consistent with the definition of genetic code in BIOCHEMISTRY, supra note 88 , at 816 ("The correspondence between a particular three nucleotide codon and the amino acid it specifies. The standard genetic code of 64 codons is used by almost all organisms. The genetic code is used to translate the sequence of nucleotides in mRNA into protein.").

${ }^{426}$ Assoc. for Molecular Pathology v. USPTO, 702 F. Supp. 2d 181, 194-95 (S.D.N.Y. 2010).

${ }^{427}$ Assoc. for Molecular Pathology, 689 F.3d at 1340 (Moore, J., concurring in part).

${ }_{428}$ Id.

${ }^{429}$ Id. at $1340-41$.
} 
in a cell which does not normally produce it." ${ }^{430}$ Judge Bryson concluded "the cDNA has a utility not present in the naturally occurring BRCA DNA and mRNA because cDNA can be attached to a promoter and inserted into a non-human cell to drive protein expression." 431 Yet cDNA encodes the same protein as DNA, but since cDNA is produced from mRNA, cDNA produces the proteins without the first transcription step of natural DNA. ${ }^{432}$

On the other hand, DNA segments with introns produce the same result - the same proteins - as the cDNA, only through an additional step. This additional step should not lead to a different outcome in the patentable subject matter analysis. As the Supreme Court held in Badische, "[w]hile a new process for producing it was patentable, the product itself could not be patented, even though it was a product made artificially for the first time, in contradistinction to being eliminated from the madder root." $" 433$ Similarly, the human-performed step of mixing bacteria into a paste in Funk Brothers did not cause the combination of bacteria to become patentable subject matter. ${ }^{434}$

Aside from the removed introns that do not code for applicable proteins, the sequence of bases in claim 2 are identical to the sequence of coding bases in native DNA and the bases of claim 2 perform the same function as the coding bases of native DNA. As Judge Bryson pointed out, "the genetic coding sequence that is the subject of each of the BRCA gene claims remains the same whether the gene is in the body or isolated." ${ }^{35}$ As a result, removing the introns is arguably irrelevant in determining whether the cDNA has markedly different characteristics and function than native DNA.

${ }^{430} I d$. at 1340 (emphasis in original).

${ }^{431} I d$. at $1355-56$ (Bryson, J., concurring in part and dissenting in part).

${ }^{432}$ Assoc. for Molecular Pathology v. USPTO, 702 F. Supp. 2d 181, 198-99

(S.D.N.Y. 2010) (explaining that "cDNA does not contain non-coding intronic sequences because it is derived from mRNA in which the introns have been removed. As a result, the production of proteins from cDNA does not require RNA splicing, in contrast to the production of proteins from native DNA as described above.").

433 Cochrane v. Badische, 111 U.S. 293, 31 (1884). Madder is "a Eurasian herb (Rubia tinctorum of the family Rubiaceae, the madder family) with whorled leaves and small yellowish panicled flowers succeeded by dark berries;" however it can refer broadly to "any of several related herbs (genus Rubia)." Madder, MERRIAMWEBSTER ONLINE DiCTIONARY, http://www.merriam-webster.com/dictionary/ madder (last visited Apr. 13, 2013). The "root of the Eurasian madder [was] used formerly in dyeing . . . [and] an alizarin dye [was] prepared from it." Id.

${ }^{434}$ Funk Bros. Seed Co. v. Kalo Inoculant Co., 333 U.S. 127, 129, 131 (1948).

${ }^{435}$ Assoc. for Molecular Pathology, 689 F.3d at 1351 (Bryson, J., concurring in part and dissenting in part). 
On the other hand, assume for the sake of argument that under Chakrabartry there are enough differences in the characteristics and functioning of the cDNA for claim 2 to constitute patentable subject matter. The next section argues that under Prometheus, claim 2 would still constitute unpatentable subject matter because claim 2 focuses on the genetic code without any inventive concept added to the genetic code.

\section{Nothing inventive added to the law of nature}

Although claim 2 arguably adds something beyond the law of nature - the actual sequence of the DNA - there is nothing inventive about that addition. As Judge Bryson stated, "Myriad was not the first to map a BRCA gene to its chromosomal location." "436 Judge Bryson further observed "Myriad did not invent a new method of nucleotide sequencing. Instead, it applied known sequencing techniques to identify the nucleotide order of the BRCA genes." 437 Under Prometheus, that step of identifying the nucleotide sequence is "not sufficient to transform unpatentable natural correlations into patentable applications."

Claim 2 in fact sets forth the natural correlation between nucleotides and amino acids more clearly than claim $1 .{ }^{439}$ Claim 2 identifies only the nucleotides - the exons - that code for the amino acids referred to in claim 1. Neither Myriad Genetics nor any human created such relationship inherent in nature - the genetic code. Neither Myriad nor any human added anything inventive to the genetic code claimed to warrant holding claim 2 patentable subject matter. Indeed, Myriad Genetics simply removed excess material in claim 1 that did not participate in creating the amino acids. Under Prometheus, the Federal Circuit should have held claim 2 did not constitute patentable subject matter.

${ }^{436} I d$. at 1348 .

${ }^{437} I d$. at 1349. In discussing the isolation of the DNA, Judge Bryson added, "The cleaving of covalent bonds incident to isolation is itself not inventive, and the fact that the cleaved molecules have terminal groups that differ from the naturally occurring nucleotide sequences does nothing to add any inventive character to the claimed molecules." Id. at 1355. See also Demain \& Fellmeth, supra note 82 at 400 ("If a naturally occurring DNA molecule has the useful function of coding for Protein X, then no purified or otherwise altered version of that DNA molecule can be 'new' unless its claimed function is fundamentally different than coding for Protein X.").

${ }^{438}$ Mayo Collaborative Servs. v. Prometheus Labs., Inc., 132 S. Ct. 1289, 1298 (2012).

${ }^{439}$ E.g., U.S. Patent '282, supra note 306, at fig.10A-H. As Patent '282 details, "[i]ndefinite intervals within introns are designated with vvvvvvvvvvvv," which shows that the ' 282 patent did not identify all of the introns. 


\section{CONCLUSION}

Supreme Court precedents do not become irrelevant simply because they are old, yet Judge Lourie's and Judge Moore's 2012 opinions in Myriad Genetics would suggest otherwise. The deference shown by Judges Lourie and Moore to the USPTO finds no support in Supreme Court cases. ${ }^{440}$ The isolated DNA segments of claim 1 reflect human genes that actually exist in nature, with neither substantial variation in characteristics nor variation in function. The holdings in Chakrabarty and Funk Brothers require the reversal of the Federal Circuit's decision on claim 1.

Finally, the narrow interpretation by Judges Lourie, Moore, and Bryson of Prometheus threatens to eviscerate the public domain in a vital area of scientific research. The DNA of claim 1 reflects a physical phenomenon (the sequence of nucleotides) and a law of nature (the correlation between the exons and the amino acids expressed by those exons constituting the genetic code). The cDNA of claim 2 also reflects that genetic code. If the genetic code is not a law of nature, nothing is a law of nature.

Myriad Genetics added nothing inventive to that law of nature to warrant the Federal Circuit's conclusion that claim 1 and claim 2 constituted patentable subject matter. Prometheus calls for a reversal of the Federal Circuit's decision on both claim 1 and claim 2 .

${ }^{440}$ See supra Part III.B.5. To the extent there are underlying factual disputes, there is no basis set forth in the Federal Circuit's three decisions for reversing the findings of fact of the District Court. See generally Assoc. for Molecular Pathology v. USPTO, 702 F. Supp. 2d 181, 227-32 (S.D.N.Y. 2010). 